UNIVERSIDADE DE SÃO PAULO

PROGRAMA DE PÓS-GRADUAÇÃO INTERUNIDADES

ESTÉTICA E HISTÓRIA DA ARTE

\author{
OLÍVIO GUEDES
}

\title{
A tradição judaica na obra de Modigliani
}

SÃO PAULO 


\section{OLÍVIO GUEDES}

\section{A tradição judaica na obra de Modigliani}

Tese apresentada ao Programa de Pós-graduação Interunidades Estética e História da Arte da Universidade de São Paulo para obtenção do título de Doutor.

Área de Concentração: Produção e Circulação da Arte.

Orientador: Prof. Dr. Edson Leite.

SÃO PAULO

2017 
Capa e Abertura dos Capítulos:

Detalhe, Olhos de Modigliani

(MODIGLIANI, 1984, p. 63) 


\begin{abstract}
AUTORIZO A REPRODUÇÃO E DIVULGAÇÃO TOTAL E PARCIAL DESTE TRABALHO, POR QUALQUER MEIO CONVENCIONAL OU ELETRÔNICO, PARA FINS DE ESTUDO E PESQUISA, DESDE QUE CITADA A FONTE.
\end{abstract}

Catalogação da Publicação

Biblioteca Lourival Gomes Machado

Museu de Arte Contemporânea da Universidade de São Paulo

Guedes, Olívio.

A tradição judaica na obra de Modigliani / Olívio Guedes ; orientador Edson Roberto Leite. -- São Paulo, 2017.

145 f. : il. + 1 DVD

Tese (Doutorado - Programa de Pós-Graduação Interunidades em Estética e História da Arte) -- Universidade de São Paulo, 2017.

1. Arte Moderna - França - Século 20. 2. Tradição Judaica. 3. Cabala. 4. Modigliani, Amedeo, 1884-1920. I. Leite, Edson. II. Título.

CDD 759.06 
Nome: GUEDES, Olívio.

Título: A tradição judaica na obra de Modigliani

Tese apresentada ao Programa de Pós-Graduação Interunidades Estética e História da Arte para obtenção do título de Doutor em Estética e História da Arte.

Aprovado em:

Banca examinadora

Prof. Dr. Edson Leite

Instituição: MAC-USP

Assinatura:

Prof(a). Dr(a).:

Instituição:

Assinatura:

$\operatorname{Prof}(a) \cdot \operatorname{Dr}(a) .:$

Instituição:

Assinatura:

Prof(a). $\operatorname{Dr}(a) .:$

Instituição:

Assinatura:

Prof(a). $\operatorname{Dr}(a)$.:

Instituição:

Assinatura: 


\section{AGRADECIMENTOS}

Agradeço à minha família, em especial aos meus pais, Nelly e Olívio, à minha avó Rafaela, à minha tia Nair, ao meu irmão, Bernardo, e aos meus sobrinhos, pelo exemplo e incentivo desta família de professores, advogados, dentistas e designers em buscar da sabedoria. À Rafaela, minha querida filha, à sua mãe, Ingrid, e à minha sogra, Carmem, que sempre me motivaram, e ao Gabriel, meu querido filho, sempre atento.

À Carolina Schmukler Birembau, amiga e colega do board da Universidade de Haifa. Ao meu amigo Rabino Itche e seu adorado Pai, o Rabino Shie Pasternak. À Orly, minha discípula na arte. À Jô, minha sócia na Galeria Slaviero e Guedes. A Cris Caponero a revisão do texto. Ao grupo ProCoa, sempre motivando meu caminho. Às minhas queridas alunas do Grupo Terça-feira, em que desenvolvemos o judaísmo e o mundo. Aos meus caros amigos/colegas do Clube Hebraica: Mônica Tabacnik, vicepresidente, e Avi Gelberg, presidente. A José Carlos Pasquale de Mello Freire, caro amigo, à sua mãe, Solange, e ao seu pai, José Maria. À família Bomeny: Lilian, Adriana, Liliane e Gilberto, pela criação da Casa Modigliani Brasil. A Paulo Solano, César e Diego, do Museu a Céu Aberto, responsáveis por cinco exposições no Brasil da mostra Modigliani: Imagens de uma vida, desenvolvida em conjunto com o Modigliani Institut Paris/Rome, presidido pelo querido amigo Christian Parisot, maior expert sobre Modigliani, que me concedeu a honra da parceria na realização de curador nessas exposições e em companhia dos textos do Historiador de Arte Cláudio Strinati.

À Universidade de São Paulo e ao Programa de Pós-Graduação Interunidades Estética e História da Arte pelo aprendizado e possibilidade de desenvolvimento do meu projeto. E, principalmente, a meu orientador, Prof. Dr. Edson Leite, pelo apoio e incentivo sempre constantes. 


\section{RESUMO}

GUEDES, Olívio. A tradição judaica na obra de Modigliani. 2017. 144 f. Tese (Doutorado em Estética e História da Arte) - Programa de Pós-Graduação Interunidades Estética e História da Arte, Universidade de São Paulo, São Paulo, 2017.

O presente trabalho aborda a vida do artista Amedeo Clemente Modigliani, judeu não ortodoxo, que sempre buscou um saber artístico e filosófico e que se lançou na busca da arte e da mística judaica: a Cabala. Este estudo revela a maneira como questões místicas são expostas em suas obras de modo pouco perceptível. Para atingir os objetivos propostos, foi realizada uma pesquisa bibliográfica e exploratória, em busca de um referencial teórico e prático para a compreensão e elucidação dos fatos e a demonstração de como este artista abriu-se para o mundo sem perder suas raízes fundamentadas na tradição judaica.

Palavras chave: Modigliani; Modernismo; Mística judaica; Cabala. 


\begin{abstract}
GUEDES, Olívio. A Jewish tradition in the work of Modigliani. 2017. 144 p. Thesis (Doctorate in Aesthetics and Art History) - Programa de Pós-Graduação Interunidades Estética e História da Arte, Universidade de São Paulo, São Paulo, 2017.

The present work deals with the life of the artist Amedeo Clemente Modigliani, an unorthodox Jew, who has always sought artistic and philosophical knowledge and who has launched the quest for Jewish art and mysticism: the Kabbalah. This study reveals how mystical questions are exposed in their works in a barely perceptible way. In order to reach the proposed objectives, a bibliographical and exploratory research was carried out, in search of a theoretical and practical reference for the understanding and elucidation of the facts and the demonstration of how this artist opened up to the world without losing its roots based on the Jewish tradition .
\end{abstract}

Keywords: Modigliani; Modernism; Jewish Mysticism; Kabbalah. 


\section{LISTA DE FIGURAS}

Figura 1: Pais de Amedeo Modigliani, fotografia.....................................................23

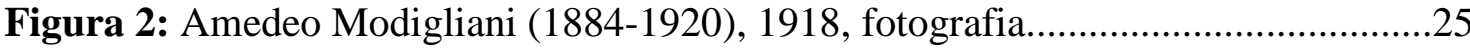

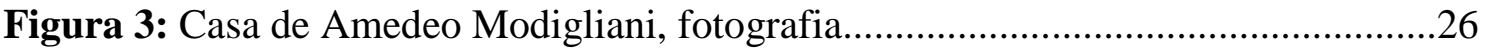

Figura 4: Árvore Genealógica, família de Modigliani..................................................30

Figura 5: Modigliani - "Jovem sentada", 1905, ost, 88 x 64 cm, coleção particular....32

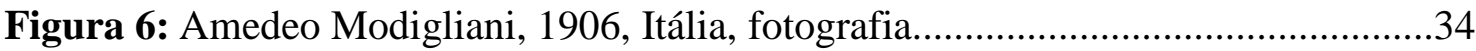

Figura 7: Modigliani - “A Amazona”, 1909, ost, 92 x 65 cm, coleção particular..........39

Figura 8: Modigliani - "Cariátide”, 1913, tsc, 34 x 23 cm, coleção particular.............41

Figura 9: Modigliani - "Cariátide”, 1914, pedra calcária, 92 x 41 x 42,9cm, MOMA

Figura10: Modigliani - "Beatrice Hastings", 1916, ost, 55 x $38 \mathrm{~cm}$, Barnes Fundation EUA.

Figura 11: Modigliani - "Paul Guillaume", 1915, ost, 105 x 75 cm, Museu de L’Orangerie. .44

Figura 12: "Modigliani em seu estúdio", 1915, França, fotografia de Paul Guillaume.

Figura 13: "Modigliani, Max Jacob, André Salmon e Zarate”, 1916, fotografia de Jean Cocteau. .46

Figura 14: Modigliani - "Simone Thiroux", 1916/18, ost, 73 x 50 cm, coleção Olga Sidamon-Eristavi.

Figura 15: Modigliani - "Jeanne Hébuterne”, 1918, ost, 46 x 29 cm, coleção particular.

Figura 16: "Convite da primeira exposição individual de Modigliani”, 1917, França, fotografia

Figura 17: Modigliani - "Rachele Osterlind", 1919, osl, 46 x 33 cm, coleção particular.

Figura 18: “Convite exposição coletiva de Modigliani”, 1919, Inglaterra, 
Figura 19: "Pedra Mortuária", 1930, Cemitério Père-Lachaise, França, fotografia......56

Figura 20: "Cabala no idioma hebraico", fotografia....................................................60

Figura 21: "Torá", livro (sefer) de rolo, fotografia......................................................61

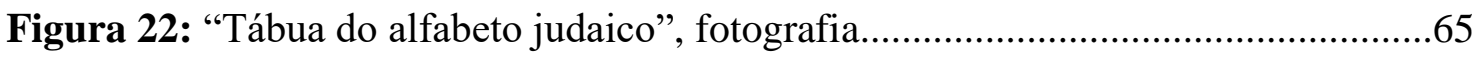

Figura 23: “Árvore Cabalista”, 1516, gravura.........................................................66

Figura 24: “A Árvore e Jessé”, 1145, vitral, Catedral de Chartres..............................67

Figura 25: “Oferenda ao Sol”, 1336 a. C., fotografia...................................................69

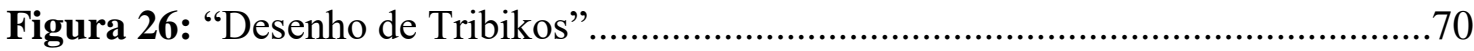

Figura 27: Modigliani - "Símbolos judaicos”, 1915, lsp, 54,5 x 43 cm, coleção

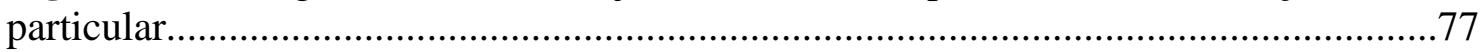

Figura 28: Modigliani - "Diego Rivera”, 1916, osp, 100 x 79 cm, MASP...................85

Figura 29: Modigliani - "Estudo da Cabala Astrológica", 1909, lsp, 30 x 17 cm.........87

Figura 30: Moricand - "Mapa astrológico de Jeanne Modigliani”, 1918, 1sp, 30 x 22

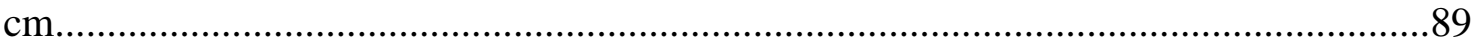

Figura 31: Modigliani - "Conrad Moricand", 1916, ost, 22 x 17 cm, coleção

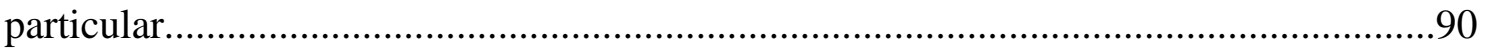

Figura 32: Modigliani - "Geometria e Cabala", 1908/?, tsp, 21 x 13 cm.....................92

Figura 33: Modigliani - “A Judia”, 1908, ost, 55 x 46 cm, Museum Kamagawa.........93

Figura 34: Modigliani - "Busto de uma jovem mulher", 1911, ost, 55 x $38 \mathrm{~cm}$,

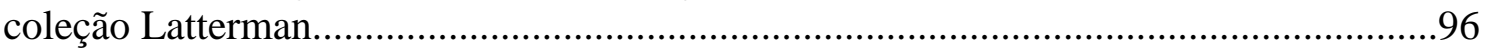

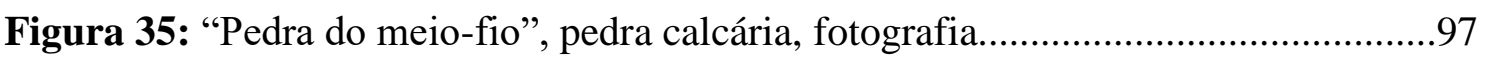

Figura 36: Modigliani - "Cabeza”, 1911/13, pedra calcária, 71,8 x 18,4 x 30,6 cm,

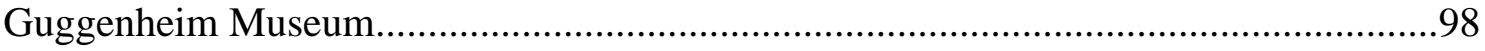

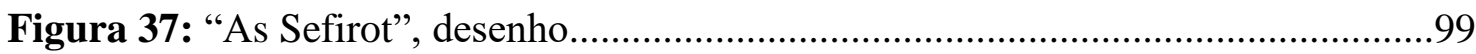

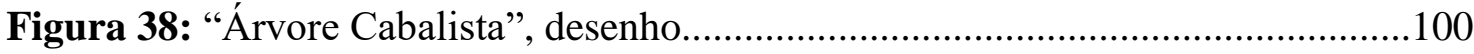

Figura 39: “Árvore Cabalista”, desenho (Detalhe)................................................101

Figura 40: Modigliani - "Busto rojo", 1913, osc, 81 x 46 cm, coleção particular......102 
Figura 41: Modigliani - "Cabala Malchut”, 1908/?, 1sp, 21 x 13 cm. 103

Figura 42: Modigliani - "Cabeza", 1912, piedra caliza, 58 x 12 x 16 cm, Centre Pompidou. 105

Figura 43: Modigliani - "Geometria e Cabala", 1908/?, tsp, 21 x 13 cm (detalhe).....110

Figura 44: Modigliani - "Leopold Zborowski”, 1916/19, ost, 106 x 66 cm, MASP...111

Figura 45: Modigliani - "Max Jacob”, 1916, ost, 73 x 60 cm, Museu Düsseldorf......113

Figura 46: Modigliani - "Nu deitado", 1917, ost, 60 x 92 cm, coleção Gianni Mattioli, Milão. 116

Figura 47: Modigliani - "Jeanne Hébuterne" e, 1918, ost, 46 x 29 cm, coleção particular, Berna, Suiça 118

Figura 48: Modigliani - “J. Hébuterne”, 1918, ost, 100 x 65 cm, coleção particular, Paris.

Figura 49: Modigliani - "Lunia Czechowska", 1919, ost, 46 x 33 cm, coleção particular.

Figura 50: Modigliani - “Autorretrato”, 1915, osc, 43 x 27 cm, SMK Denmark.......123

Figura 51: Modigliani - “Autorretrato com barba”, 1918, 1sp, coleção Alexandre, Paris.

Figura 52: Modigliani - “Autorretrato", 1919, ost, 100 x 64,5 cm, MAC/USP..........126

Figura 53: Modigliani - “Cabala Kether”, 1908/?, lsp, 21 x 13 cm

Figura 54: J. Lipchtz - "Máscara mortuária Modigliani”, 1920, gesso, 22,2 x 15,1 x $11,5 \mathrm{~cm}$, coleção Chester Dala. 


\section{SUMÁRIO}

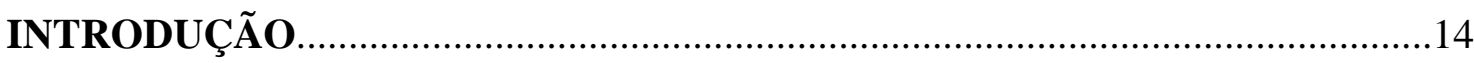

\section{CAPÍTULO 1 - MODIGLIANI: A VIDA}

1.1 Descendência, nascimento e vida na Itália..............................................22

1.2 O artista e a influência de sua mãe.........................................................28

1.3 O avô materno e a aventura do conhecimento.............................................29

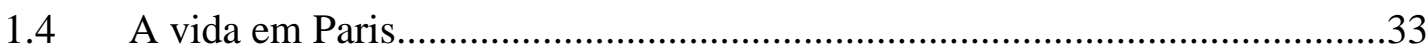

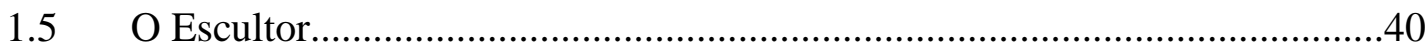

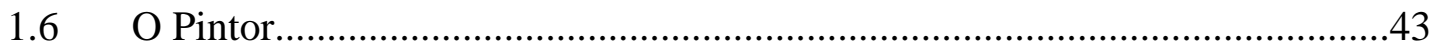

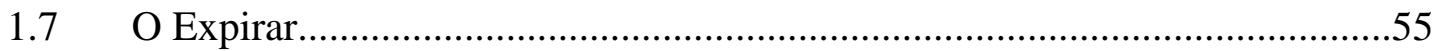

\section{CAPÍTULO 2 - A TRADIÇÃO JUDAICO-CABALISTA}

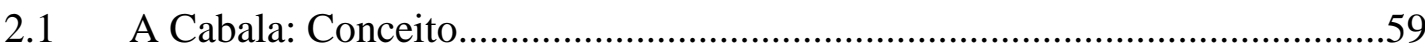

2.2 Tradição e História........................................................................................60

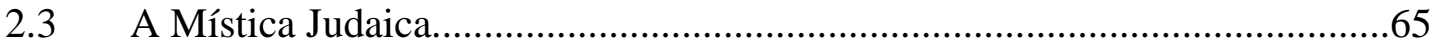

\section{CAPÍTULO 3 - A MÍSTICA JUDAICA NA OBRA DE MODIGLIANI}

3.1 Ligações para além da Arte.......................................................................

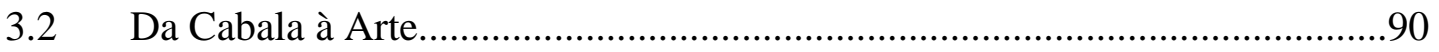

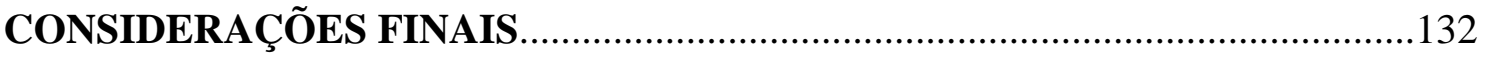

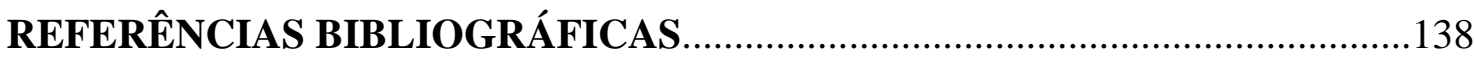

ANEXO: Breve linha do tempo sobre a vida de Modigliani.......................................143 
INTRODUÇÃO 


\section{INTRODUÇÃO}

Amedeo Clemente Modigliani foi um judeu nascido na Itália que acompanhou a arte em seu percurso inovador, característico do período em que a modernidade imprimia sua marca. Foi um homem de saúde frágil, mas de uma vontade de conhecimento extremo. Boa parte do aprendizado de Modigliani foi transmitido por seu avô materno que o introduziu no mundo das artes, apresentando-lhe os museus, grandes templos da sabedoria, e a mística judaica.

Modigliani viveu no período das grandes vanguardas: impressionismo, pósimpressionismo, expressionismo, divisionismo, simbolismo, hermetismo, dadaísmo, fauvismo, cubismo e futurismo, conhecendo profundamente tais estilos e bebendo destas fontes, mas mantendo seu estilo próprio. Sua técnica única existia por causa de sua personalidade, forjada no seio de uma cultura eclética e de conteúdo judaico. Sua base familiar, de tradição sefardita ${ }^{1}$, mantinha suas tradições e Modigliani fez o mesmo em suas obras, de maneira bastante discreta.

Em suas obras, ele ressaltou questões humanitárias, antropológicas e religiosas e a profundidade artística característica do período em que foram produzidas, mas imprimindo sua marca pessoal. No período em que produziu retratos eles não estavam mais na moda, pois já havia surgido a fotografia e as máquinas estavam em plena utilização mas, mesmo assim, continuou a pintá-los.

\footnotetext{
${ }^{1}$ A tradição sefardita refere-se aos judeus originários do Oriente Médio. Sefarditas são judeus cuja ascendência remonta às comunidades judaicas ibéricas (Espanha e Portugal) estabelecidas na Idade Média e dispersas por várias regiões da Europa ocidental, Norte da África, Turquia, Bálcãs e Américas (UNTERMAN, 1992).
} 
Modigliani é um artista de grande destaque no meio artístico e no mercado de arte. Em 2015, por exemplo, uma de suas obras, $\mathrm{Nu}$ couché ( $\mathrm{Nu}$ deitado) (Figura 46), atingiu a segunda posição no ranking de valores no mercado de arte internacional ${ }^{2}$.

Tendo em vista a importância, artística da pintura de Modigliani, a escolha do tema da presente tese teve origem na busca pela compreensão profunda da relação entre arte, relacionamento, representação artística e seus desdobramentos. Este tema encontrou seu foco na pesquisa religiosa e simbólica da arte e na História da Arte, abarcando sua origem e desenvolvimento através da análise das obras de Modigliani.

Desta forma, o objetivo geral da presente tese foi a identificação das possíveis relações entre as obras produzidas por Amedeo Clemente Modigliani com as tradições e influências judaico-cabalistas, o que envolveu, inclusive, uma imersão no conteúdo histórico, na busca da história das ligações tradicionais familiares e na origem judaica do artista no conteúdo filosófico, religioso e econômico de produção das mesmas, e no seu envolvimento com a arte. O estudo das obras de Modigliani visou à interpretação do ato criativo e sua relação com a tradição familiar, religiosa e social (GUINSBURG, 1967).

O presente trabalho também visou a analisar da trajetória do artista Modigliani e o desenvolvimento de seu estilo próprio a fim de compreender sua arte, no contexto histórico e no ambiente cultural e artístico da Itália e da França onde viveu, assim como a relevância de sua obra para a cultura internacional.

Dentre os objetivos específicos, destacamos:

1) Compreender a significativa importância de Amedeo Modigliani e de suas as obras em sua universalidade;

\footnotetext{
${ }^{2}$ Sua obra $\mathrm{Nu}$ couché (Nu deitado) (Figura 46) foi a segunda obra mais cara vendida em leilão. Foi à praça em 10/11/15 na Christie's, de Nova Iorque, por 100 milhões de dólares e acabou sendo comprada por 170,4 milhões de dólares - um valor não muito distante do recorde batido por Les femmes d'Alger, de Pablo Picasso, arrematada por 180 milhões de dólares.
} 
2) Compreender a origem das características próprias das obras de Modigliani e suas ligações interdisciplinares, frente ao conteúdo histórico e social da época de sua produção;

3) Verificar a influência judaica nas obras de Modigliani;

4) Associar a configuração das obras de Modigliani com o conteúdo cabalístico e verificar, inclusive, se o emprego da simbologia judaicocabalista em sua obra pode ser considerado intencional.

Uma das maiores dificuldades quanto à pesquisa desenvolvida foi a inexistência de qualquer trabalho que abordasse a relação da produção cabalista com a arte de Modigliani, o que, inclusive, justifica a importância e originalidade de presente estudo. Partimos, então, da seguinte hipótese:

- Modigliani foi um dos artistas de maior destaque no século XX cujas obras sofreram influências profundas da tradição judaica.

Nossa tese é que o conteúdo das obras de Amedeo Clemente Modigliani, especialmente nos retratos foi influenciado pela tradição judaica-cabalista, incluindo as questões relacionadas com os deslocamentos do povo de origem hebraica por vários países na Europa, numa constante diáspora, o que interferiu na criação e no desenvolvimento de sua criatividade artística.

A produção artística de Modigliani, em seu mundo representativo - o mundo da arte -, apresenta estudos que permitem estabelecer a ligação com a religião de sua família. As características plásticas de sua obra são únicas e apresentam diversas peculiaridades em relação a outros estilos e pintores. 
A compreensão da história pode nos levar a um maior aprofundamento dos estudos que englobam esse envolvimento e pode indicar a necessidade de outros estudos sobre o significado do mundo simbólico na obra de Modigliani.

A criação de Modigliani encontra no modernismo outros valores, para além dos religiosos e, seu caminhar com a modernidade tem um efeito grandioso em suas obras. Sua condição inicial se qualifica e se transforma. Suas obras têm um significativo reconhecimento que vai aumentando com o decorrer do tempo e que deixam transparecer, com a pesquisa, a influência das tradições ancestrais de sua origem judaica.

Quanto à sua criatividade, suas formas de expressão estão agregadas às próprias questões do hibridismo arte-história-religião. Suas obras vêm transmitindo, há gerações, o sentimento de identidade, pertencimento e continuidade; seu trabalho, a partir de sua origem judaico-europeia, contribui e promove a questão do respeito à diversidade cultural (UNTERMAN, 1992).

Para refletir sobre a problemática apresentada, assim como analisar e elucidar os fatos e atingir os objetivos propostos, foi fundamental passarmos por um quadro teórico de referência. Foram analisados conceitos essenciais relativos ao conteúdo histórico e à cultura, buscando a melhor clareza dos fatos, sua interpretação, compreensão e maior abrangência da realidade.

Para a realização deste trabalho, foi também necessária identificação da atividade artística de Modigliani, coletando dados e informações que nos permitissem evidenciar a representação da tradição judaico-cabalistas em seus retratos, através de fatos históricos, fotos, análise de suas obras etc. Modigliani exerceu intensa atividade como escultor e pintou vários gêneros, mas optamos pela analise de alguns de seus retratos nesta pesquisa. 
Foi realizada uma pesquisa bibliográfica e documental em fontes secundárias.

Segundo Gilberto de Andrade Martins:

Pesquisa bibliográfica trata-se de estudo para conhecer as contribuições científicas sobre determinado assunto. Tem como objetivo recolher, selecionar, analisar e interpretar as contribuições teóricas já existentes sobre determinado assunto. A pesquisa documental tem por finalidade reunir, classificar e distribuir os documentos de todo gênero dos diferentes domínios da atividade humana. A pesquisa de campo corresponde à coleta direta de informação no local em que acontecem os fenômenos (MARTINS, 1994, p. 28).

Também foi realizada uma pesquisa exploratória, tendo em vista a pouca

literatura disponível, a fim de apresentar o estado da arte em que o tema se encontra, conduzindo à necessidade de concentração dessas informações. Segundo Roberto Sampieri, Carlos Collado e Pilar Lucio, os estudos exploratórios podem servir para a familiarização com fenômenos relativamente desconhecidos e devem ser realizados:

(...) quando 'o objetivo é examinar um tema ou problema de pesquisa, pouco estudado, do qual se tem muita dúvida ou não foi abordado antes'. Em outras palavras, quando a revisão de literatura revela que há temas não pesquisados e ideias vagantes relacionadas com o problema de estudo; ou seja, se desejarmos pesquisar sobre alguns temas e objetos com base em novas perspectivas e ampliar os estudos já existentes (SAMPIERI; COLLADO; LUCIO, 2006, p. 99).

O tema então elucidado, compreendido e esclarecido, juntamente com o material bibliográfico, demonstrou a realidade social na sua complexidade, à luz da análise teórico-conceitual. Com isso, foi possível fazer uma reconstituição histórica da vida e da obra de Amedeo Clemente Modigliani.

A presente tese apresenta-se assim organizada: Introdução; Capítulo 1 Modigliani: A Vida; Capítulo 2 - A Tradição Judaico-Cabalista; Capítulo 3 - A 


\section{Mística Judaica na Obra de Modigliani; Considerações Finais, Referências}

Bibliográficas e Anexo, abordando questões importantes para a compreensão de nossa temática e para atingir os objetivos propostos.

No Capítulo 1 - Modigliani: A Vida, realizamos o levantamento histórico da vida familiar de Modigliani e sua iniciação no mundo das artes e da mística judaica, assim como suas relações pessoais e sociais. O objetivo principal deste capítulo foi demonstrar como a obra e as relações estabelecidas por Modigliani fazem parte de um mesmo contexto temporal e histórico relacionado com a trajetória do modernismo internacional, enquanto movimento artístico desenvolvido na Europa do século XX.

No Capítulo 2 - A Tradição Judaico-Cabalista, abordamos o entendimento da mística judaica através dos livros da Cabala. Pesquisamos a mística judaica, suas experiências e contribuições para uma possível compreensão do artista Modigliani e de suas obras. No Capítulo 3 - A Mística Judaica na Obra de Modigliani, abordamos questões referentes à arte e ao simbolismo judaico, buscando compreender as técnicas, os temas e, sobretudo, a interpretação judaico-cabalista encontrada na obra de Modigliani, confirmando então a nossa tese.

Nas Considerações Finais demonstramos como as hipóteses iniciais a princípio elencadas foram confirmadas, atendendo aos objetivos propostos e contribuindo para eventuais trabalhos futuros que venham a complementar os estudos sobre a vida e a obra Modigliani sob influência cabalística que, embora mística, é aberta ao mundo de forma ímpar e artisticamente absoluta.

Apresentamos as Referências Bibliográficas com todas as fontes citadas no decorrer da tese.

Finalizando este trabalho com o Anexo: Breve linha do tempo sobre a vida de Modigliani. 
Cabe mencionar ainda que na capa da presente tese, assim como na abertura de todos os capítulos, utilizamos a imagem Olhos de Modigliani, (MODIGLIANI, 1984, p. 63), dada a importância atribuída aos olhos e ao olhar pelo artista em suas obras. Modigliani acreditava que o maior pertencimento se encontra no olhar e são, exatamente os olhos que, fitam o observador e que ganham importância e valor em suas obras, podendo ser observados em grande parte delas. 


\section{CAPÍTULO 1}

MODIGLIANI: A VIDA 


\title{
CAPÍTULO 1 - MODIGLIANI: A VIDA
}

\begin{abstract}
Não há nenhum poeta ou artista totalmente decifrável em seu dizer ou em seu fazer. Modigliani é um deles e é neste intervalo misterioso entre o arcaico e o seu tempo que se oculta à origem de sua inspiração e sua própria leitura do mundo (STRINATI, 2012, p. 47).
\end{abstract}

Artista é um indivíduo que tem a capacidade de transformar a matéria in natura, portanto: a arte artificializa, transforma a coisa em algo. Este algo pode ser apenas um utensílio, mas para que este utensílio se transforme em um objeto, e para este que objeto exista como objeto de arte, há um longo caminho a ser percorrido. (ARGAN, 1992). Assim, o humano que se torna consciente $^{3}$ (DAMÁSIO, 2015) de si e compreende o outro, tem inteligência, sabedoria e poderá Ser artista.

\subsection{Descendência, nascimento e vida na Itália}

A família de Amedeo Clemente Modigliani, por parte de pai, composta por judeus sefarditas, chegou à cidade de Livorno, Itália, em 1849, vindos de Modigliana, aldeia da Emilia-Romagna, perto de Forlì, Região Norte da Itália. Lá, prestavam importantes serviços financeiros a um cardeal, como penhoristas. Segundo a história relatada por Jeanne, filha de Modigliani (MODIGLIANI, 1984), Flaminio Modigliani (1840-1928), o pai de Amedeo, foi comerciante de minério (zinco) na Sardenha e teve grande desenvolvimento financeiro, pois, percebendo a necessidade de um hotel na região, fundou o Lion $D^{\prime}$ or, em 1872, que era frequentado por pessoas favorecidas social e economicamente. Foi lá que Flaminio veio a conhecer seu futuro sogro, Isacco Garsin.

\footnotetext{
${ }^{3}$ O Consciente é o momento do conhecimento de sua própria existência e capacidade de pensar, desejar e perceber, que envolve raciocínio e percepção, estado de posse plena de suas faculdades mentais (DORIN, 1978).
} 
A família de Amedeo Clemente Modigliani, por parte materna, também é sefardita, mas de origem espanhola. Sua mãe chamava-se Eugénie Garsin (1855-1927) e era filha de Isacco e Reginetta Garsin. A avó de Reginetta, portanto tataravó de Modigliani, chamava-se Regina Spinoza, e era descendente do filósofo Baruch Spinoza (1632-1677), criador do spinozismo ${ }^{4}$. A família Garsin, por questões étnicas e para evitar preconceitos, mudou-se para Túnis, na Tunísia, no século XVIII, onde desenvolveu uma escola talmúdica ${ }^{5}$. Em 1849, a família chegou à Marselha, na França.

A decisão do casamento de Eugénie Garsin com Flaminio Modigliani foi tomada pelos pais dela, pois, na época, ela tinha apenas 17 anos. O recém-formado casal foi morar em Livorno, com a família Modigliani, que naquele momento era bastante abastada. A Figura 1 mostra os pais de Modigliani.

Figura 1: "Pais de Amedeo Modigliani", fotografia

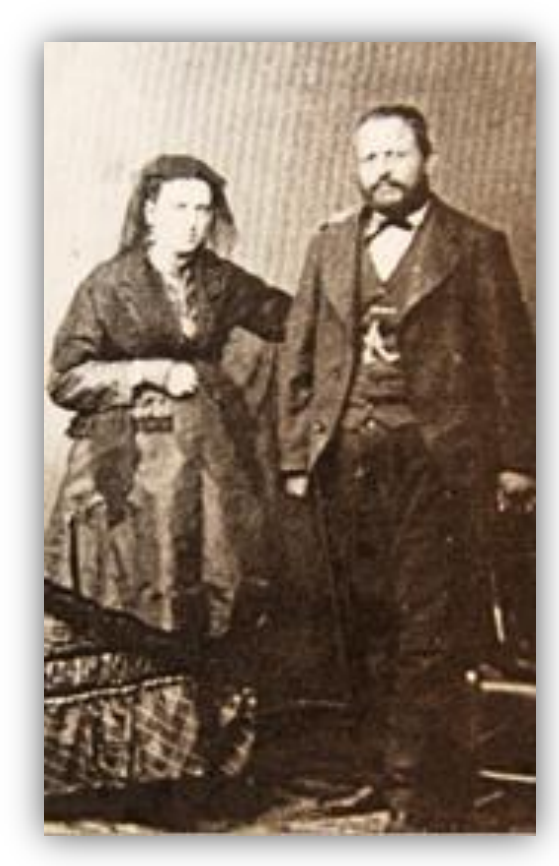

Fonte: PARISOT, 2006, p. 25.

\footnotetext{
${ }^{4}$ O spinozismo é a doutrina do filósofo holandês Baruch Spinoza (1632-1677), segundo a qual a realidade divina, desprovida de seu tradicional caráter transcendente, é identificada à natureza, à totalidade infinita do real, sendo a sabedoria o amor intelectual ao $D^{\prime} u s$ imanente.

${ }^{5}$ A escola talmúdica teve origem no conjunto de ensinamentos contidos no Talmud.
} 
Livorno é uma cidade murada da Renascença italiana, planejada por Bernardo Buontalenti (1531-1608), arquiteto do final do século XVI. É uma cidade labirinto, com torres, fortalezas e com bairros cortados por canais. Em 1580, Fernando I de Médici declarou Livorno um "Porto Franco", uma cidade isenta de impostos, com um porto que era um dos mais importantes da região mediterrânea. A cidade tornou-se pluricultural, com mercadores judeus, armênios, gregos, holandeses, ingleses e mouriscos vivendo em liberdade social, cultural e religiosa, além de poderem comercializar livremente. No entanto, durante as guerras napoleônicas (1803-1815), foi proibido o comércio com a Inglaterra, o que levou a cidade a uma queda em seu comércio. Em 1868, com o surgimento do Reino da Itália, o "Porto Franco" deixou de existir acarretando, consequentemente, o declínio acentuado da cidade de Livorno.

Durante uma década, o relacionamento de Eugénie com o marido, Flaminio, foi de poucos encontros. Ele retornava a Livorno somente na Páscoa e em alguns outros dias no verão.

Amedeo (amado por $D^{\prime} u s^{6}$ ) Clemente Modigliani (Figura 2) nasceu na Itália, em Livorno, na Via Roma n 38 (Figura 3), em 12 de julho de 1884 (ano 5645 no calendário judaico $^{7}$ ), às 09 h00, numa sexta-feira, sob o signo de câncer.

Na Figura 2, apresentamos a fotografia de Modigliani realizada em 1918, quando estava com 34 anos.

\footnotetext{
${ }^{6}$ A escrita $D^{\prime} u s$ utilizada no texto é uma das formas de grafia em língua portuguesa apropriadas por judeus para se referirem a Deus (formato no português e cristão), sem citar seu nome completo, em respeito ao terceiro mandamento recebido por Moisés pelo qual $D^{\prime} u s$ teria ordenado que seu nome não fosse falado em vão. Utilizaremos também deus, apenas como um ser potente.

${ }^{7}$ Calendário utilizado pelos judeus, desde o nascimento de Adão até os dias de hoje.
} 
Figura 2: “Amedeo Modigliani”, 1918, fotografia

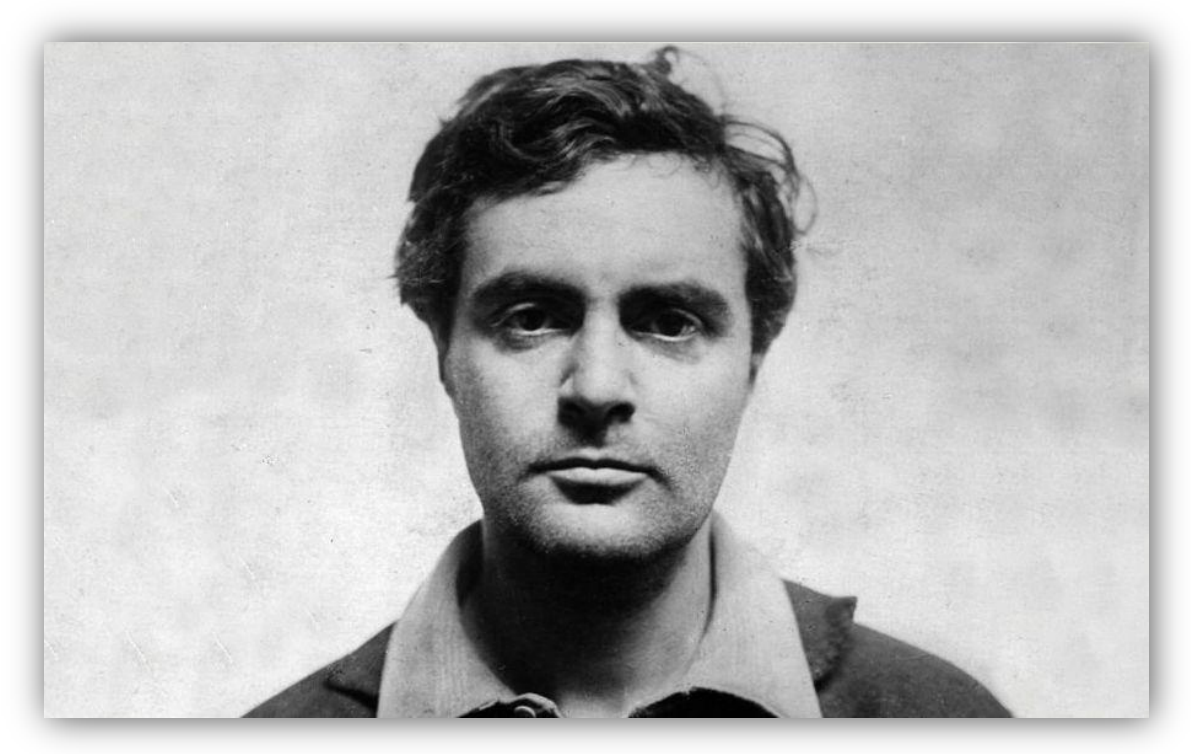

Fonte: MODIGLIANI, 1984, p. 63.

Modigliani é o quarto filho do casal, portanto, teve três irmãos: Giuseppe Emanuelle, Margherita e Umberto. Giuseppe Emanuelle Modigliani (1872-1947) era o mais velho, foi político antifascista, que se formou em Direito e se aproximou do Partido Socialista. Ele foi um dos fundadores da Seção de Livorno do Partido, tornandose vereador. Emanuel promoveu a criação de Câmaras de Trabalho, em Livorno, Pisa, Siena e Maremma. Contribuiu para a revista Socialist La Martinella de Colle di Val d'Elsa, na qual se ocupou de vários comícios. Posteriormente, prestou Serviço Militar e foi nomeado Secretário do Partido Socialista na Toscana. 
Figura 3: "Casa de Amedeo Modigliani”, fotografia

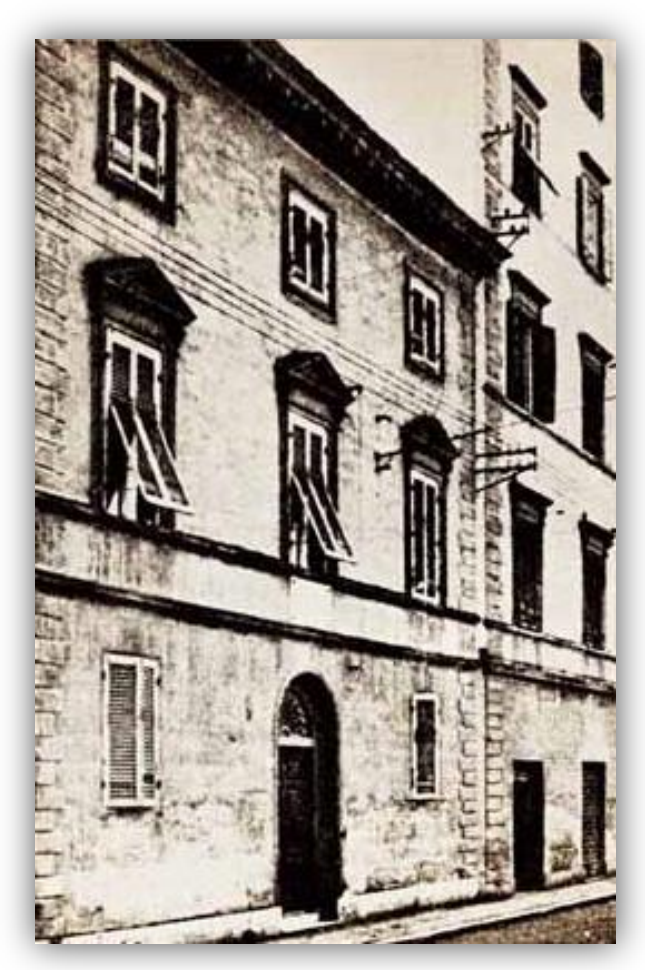

Fonte: PARISOT, 2006, p. 27.

A história dos judeus na Toscana, especificamente em Livorno, é constituída por judeus sefarditas, grupo particularmente altivo e orgulhoso de suas origens e tradições:

Em Livorno a cultura e tradições sefarditas eram, sim, vivenciadas nas casas e especialmente naquelas das velhas famílias que constituíam sua nobreza e aristocracia mas, mais do que tudo, no Templo e ao redor do Templo, nas escolas e ao redor das escolas (CAMPAGNANO, 2007, contra-capa).

Assim, Livorno, cidade natal de Modigliani, deu-lhe bases profundas sobre o judaísmo. Nessa cidade, em julho de 1897, realizou seu Bar Mitzva ${ }^{8}$ na antiga sinagoga da cidade, edificada em 1603. Desde o século XVII, a população judaica era muito

\footnotetext{
${ }^{8}$ Quando um judeu atinge a sua maturidade, aos 12 anos e um dia de idade para as meninas; e aos 13 anos e um dia para os rapazes, passa a se tornar responsável pelos seus atos. De acordo com a lei judaica, estabelece-se que o menino passa a ser Bar Mitzvá הוצמ רב, "filho do mandamento"; e a menina passa a ser Bat Mitzvá הוצמ תב, "filha do mandamento" (UNTERMAN, 1992).
} 
conhecida na cidade. Cabe destacar que em Livorno as pessoas tinham total liberdade para viver com seus cultos e suas posses, enquanto que, naquele mesmo período, em outras localidades da Europa, elas eram perseguidas. Assim, vivendo com tranquilidade, a comunidade judaica foi crescendo naquela cidade, tendo a possibilidade de ampliar e refinar suas vidas e a sinagoga, reconhecida por seu esplendor. A família de Modigliani, pelo lado materno, os Garsin, viveu em Livorno desde o final do século XVIII e sua família do lado paterno, especificamente desde 1849.

\begin{abstract}
Os judeus espanhóis e portugueses eram brilhantes herdeiros de gerações de judeus que haviam ocupado, em seus países de origem, posições muito importantes: estavam convencidos do maior requinte de seus costumes, de sua capacidade superior de produzir e investir suas riquezas, de seu cosmopolitismo em suas relações comerciais, de serem nobres mais por convicção que por linhagem. Arrogantes e valentes eram, assim, os judeus que deram força à vida judaica em Livorno (CAMPAGNANO, 2007, p. 87).
\end{abstract}

A Itália passou pelo Risorgimento ${ }^{9}$ de Vittorio Emanuele II e de Napoleão III, em 1859, que iniciaram um processo de unificação da Itália. Em 1870, Roma foi nomeada a capital de um reino laico. Após a unificação, especificamente a partir de 1887, o Norte da Itália passou a se industrializar rapidamente, num processo protecionista que detinha altas taxas alfandegárias, dificultando as exportações. O que interpunha o desenvolvimento italiano era primeiramente o pequeno mercado consumidor agrícola, depois a falta de capital para a indústria e, finalmente, a falta de mercado de trabalho. Na questão eleitoral, apenas $2 \%$ da população exercia o direito ao voto, já que era necessário para tal ter mais de 25 anos, ser alfabetizado e pagar no mínimo 40 liras de impostos anuais. Em 1900, Humberto I foi assassinado, subindo ao trono seu filho, Vitor Emanuel III. Seu gabinete era liderado por Giolitti, do Partido Liberal, que conseguiu neutralizar a atuação dos demais partidos, tornando-se figura

\footnotetext{
${ }^{9}$ Risorgimento (em italiano) ou Ressurgimento (em português) foi o movimento na história italiana que buscou entre 1815 e 1870 unificar o país, que até então era uma junção de pequenos Estados submetidos a potências estrangeiras.
} 
dominante até o início da Primeira Grande Guerra (1914-1918). Nesse período Modigliani estava com 22 anos e já vivia na França desde 1906.

\subsection{O artista e a influência de sua mãe}

Modigliani nasceu artista. O conteúdo genético herdado de sua família parece ter sido determinante. Seus pais, avós e bisavós prepararam-no para ser um artista de alma. Já em 1886, Eugénie iniciou um diário (escrito em francês) no qual se perguntava: Será ele um artista?

Quando seu pai passou a apresentar dificuldades financeiras, sua mãe juntamente com a irmã dela, Laure, fundou uma escola de francês. Eugénie também falava inglês e italiano. Assim, Modigliani teve duas línguas maternas: o italiano e o francês, o que facilitou sua futura vida na França, com a mente preparada para outros idiomas. Seus futuros amigos vieram de vários países: Espanha, França, Inglaterra, Polônia, Portugal e Rússia.

Modigliani foi uma criança fisicamente doente, que contraiu pleurisia ${ }^{10}$ e febre tifoide $^{11}$. Ele estudou no Ginnasio Guerrazzi, na Via Ernesto Rossi, perto de sua casa mas, em função da doença que o acometia e o impossibilitava de transitar normalmente, teve que abandonar a escola, passando a estudar em casa, com sua mãe, que lhe ministrava o ensino de poesias e ensaios. Ela o tratava por Dedo, apelido de Amedeo. A fragilidade da saúde de Amedeo o uniu muito a sua mãe. Este relacionamento femininoamoroso-maternal fez do futuro homem um admirador, não um simples admirador/sedutor, mas um amante da 'anima' que, por uma verdadeira busca interior -

\footnotetext{
${ }^{10}$ Pleurisia é a inflamação aguda ou crônica da pleura (pulmão), de origem bacteriana.

${ }^{11}$ Febre tifoide é uma doença infectocontagiosa causada por várias espécies de microrganismos.
} 
o encontro da alma humana -, compreenderia a alma feminina, criadora a grande mãe arquetípica que seria exaltada em suas obras (DORIN, 1978).

Sua preocupação com a alma feminina vem ao encontro de um conhecimento antigo e profundo. Busca a origem da dor na mulher, desde o período das cariátides ${ }^{12}$; período persa quando a cidade de Caria foi invadida (PIJOAN, 1969). Ao trabalhar suas cariátides no formato de herma ${ }^{13}$, Modigliani transmitiu os segredos hermenêuticos ${ }^{14}$ nos quais, o deus grego Hermes evidencia seus saberes ocultos, seus signos, como o caduceu $^{15}$, que pertence ao significante corpo e ao significado alma. No final do século XIX e início do século XX, alguns artistas, com seus conhecimentos, tratam destes estilos, como por exemplo os simbolistas $^{16}$ e os hermeneutas ${ }^{17}$ que almejavam desenvolver trabalhos importantes e profundos, que revelariam a base no mundo das artes que estaria por vir (JANSON, 1994) surgindo, então, os Nabis ${ }^{18}$ e artistas como Paul Cézanne (1839-1906) e Marcel Duchamp (1887-1968).

\subsection{O avô materno e a aventura do conhecimento}

Modigliani foi um jovem de corpo fraco, mas com o espírito forte. A vida deulhe um grande presente, um grande mestre, Isacco Garsin (1799?-1894), seu avô materno, judeu religioso que licenciou a busca pelos saberes nesse jovem ansioso por

\footnotetext{
${ }^{12} \mathrm{O}$ modelo cariátides é um suporte arquitetônico, originário da Grécia antiga, que se apresentava quase sempre com a forma de uma estátua feminina e cuja função é sustentar um entablamento.

${ }^{13}$ A herma é qualquer busto ou figura em meio-corpo, que se sustenta por um plinto, mísula ou hermeta.

14 Os hermenêuticos têm por objeto a interpretação de textos religiosos ou filosóficos, voltada à interpretação dos signos e de seu valor simbólico.

${ }^{15} \mathrm{O}$ caduceu é uma insígnia ou divisa com a imagem do deus Hermes ou Mercúrio. É o símbolo da medicina, utilizado a partir do século XVI.

${ }^{16}$ Os Simbolistas pertencem ao movimento literário e artístico do fim do século XIX que surgiu na França como reação ao Realismo e ao Parnasianismo e que, por sua visão subjetiva, simbólica e espiritual do mundo, situava o valor da obra de arte não na tradução fiel da realidade, mas na combinação subjetiva de sentimentos e de pensamentos, de figuras e de formas regidas por leis próprias (LACLOTTE, 1997).

${ }^{17}$ Hermeneuta é o termo relativo à interpretação dos textos, do sentido das palavras, voltado aos signos e símbolos.

${ }^{18}$ Nabis é o termo relativo ao grupo de artistas franceses do final do século XIX, que foram influenciados pelos simbolistas.
} 
conhecimento. O avô Isacco apresentou-lhe os museus e como religioso e também pesquisador de outros saberes, ofereceu-lhe a mística ${ }^{19}$ judaica contida na Cabala, contava sete anos. Seus ascendentes do século XVIII dirigiam, em Túnis, uma escola de Talmud (como veremos no Capítulo 2). Isacco sempre falava de seu ascendente, do Século das Ciências (séc. XVII), Baruch Spinoza (PARISOT, 2006), e o incorporou na árvore genealógica da família (Figura 4). Amedeo tinha apenas dez anos, quando do falecimento de seu avô, em 1894, e sentiu muito a ausência do querido mestre.

Figura 4: "Árvore Genealógica”, família de Modigliani, gráfico

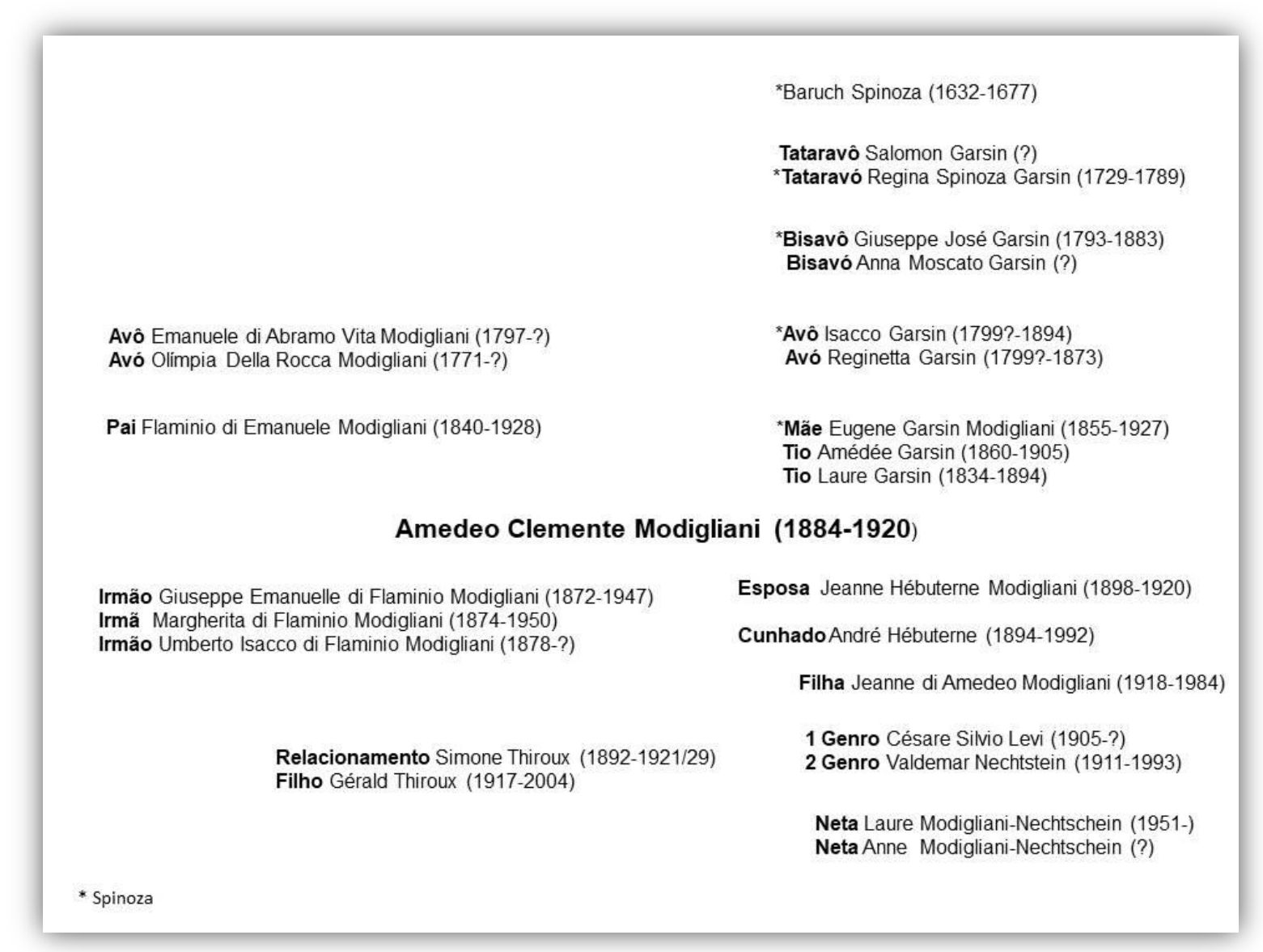

Fonte: MODIGLIANI, 1984, p. 250.

\footnotetext{
${ }^{19}$ A mística é o conhecimento ou estudo do misticismo, tendência para a vida religiosa e contemplativa, com ocupação contínua da mente nas doutrinas e práticas religiosas; fervor religioso que faz o místico alcançar um estado de êxtase, paixão e cujo objeto é a divindade (LAFFONT, 1972).
} 
Em 1898, um ano após seu Bar mitzvá, Amedeo adoeceu com febre tifoide, o que o levou a viver grande parte de sua infância e adolescência em sua residência. $O$ esforço físico, um simples brincar, era difícil, o que o levou, a se dedicar à cultura. Foi estudar Arte na Scuola da Guglielmo Micheli ${ }^{20}$, dando início aos estudos de pintura com o próprio professor Guglielmo Micheli, com que também estudaram Gino Romiti, Oscar Ghiglia, Aristide Sommati, Benvenuto Benvenuti, Renato Natali, Llewelyn Lloyd, Manlio Martinelli e Lando Bartoli (ARGAN, 2003).

Neste mesmo período, seu irmão, Emanuelle Modigliani, foi mandado para a prisão por seis meses, devido as suas atividades políticas. Posteriormente, ele viria a ser um famoso membro do Partido Socialista Italiano como mencionamos anteriormente.

Em 1902, aos 18 anos de idade, a saúde de Modigliani teve uma recaída. Com ameaça de tuberculose, mudou de ares, viajando por Florença, Roma, Nápoles e Capri. No entanto, suas dores fortaleciam sua alma. Assim, com a necessidade de transbordar, aparece mais o artista. Nesse mesmo ano, inscreveu-se na Scuola Libera di Nudo, em Florença, e pôde se aprofundar no estudo sobre o Renascimento (TEIXEIRA, 1985).

Em 19 de março de 1903, Modigliani matriculou-se no Istituto di Belle Arti di Venezia. O estudo "Jovem Sentada" (Figura 5) foi executado em 1905, tendo sido pintado em Veneza, quando Modigliani estava com 21 anos. É possível perceber a expressão interrogativa representada na obra, além da presença do sintetismo, que será uma de suas marcas mais profundas na elaboração pictórica e a luminosidade intensa. $\mathrm{O}$ maior pertencimento encontra-se no olhar, exatamente nos olhos que fitam o observador e que poderá ser observado em grande parte de suas obras, principalmente em sua pintura "O Autorretrato" (Figura 52).

\footnotetext{
${ }^{20}$ Guglielmo Micheli (1866-1926) foi um pintor italiano, discípulo de Giovanni Fattori (1825-1908), e professor de Amedeo Modigliani. Da Influência de Fattori veio o Macchiaioli, técnica de manchas. Micheli viveu em Livorno, onde seu estúdio tornou-se uma escola para muitos pintores do pósmacchiaiolo (LACLOTTE, 1997).
} 
Figura 5: Modigliani - "Jovem sentada", 1905, ost, 88 x 64 cm, coleção particular

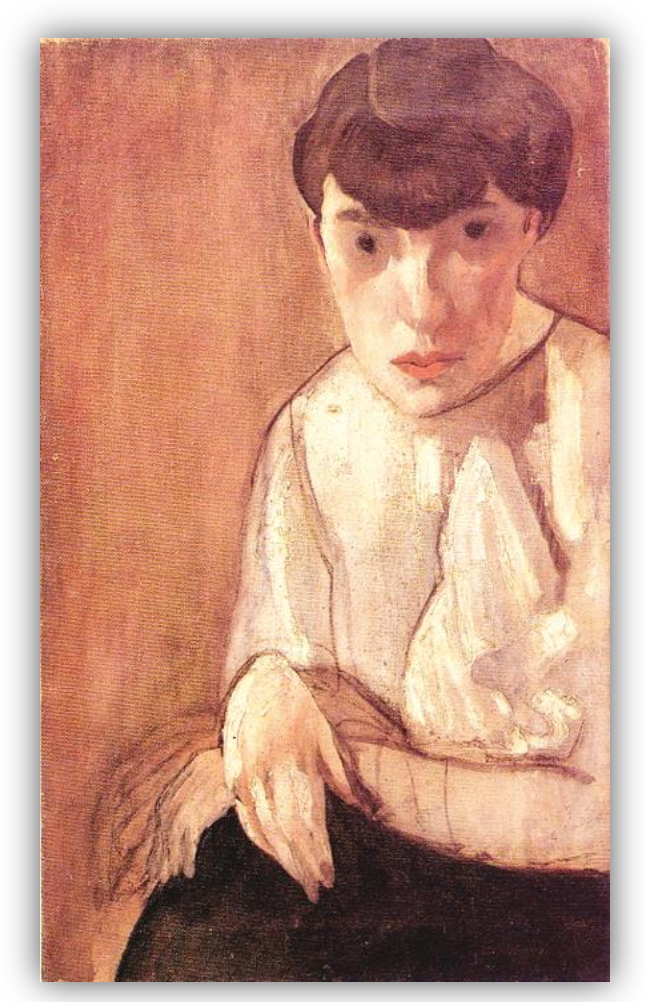

Fonte: GUEDES; PARISOT; STRINAT, 2012, p. 90.

Nesse período, Modigliani dedicou-se aos grandes mestres do passado e se inseriu na corrente do Simbolismo, pois havia visto as obras dos impressionistas franceses e as esculturas de Rodin nas Bienais de 1903 e de 1905. Ele também conheceu, neste período, Ortiz de Zarate $^{21}$ e Ardengo Soffici ${ }^{22}$ com os quais iria se reencontrar futuramente, em Paris (BAYET, 1980).

\footnotetext{
${ }^{21}$ Ortiz de Zárate (1887-1946) foi um pintor chileno. Manuel Ortiz de Zárate Pinto, filho do compositor chileno Eleodoro Ortiz de Zárate. Irmão do pintor Júlio Ortiz de Zárate (1885-1943). Estudou na Escuela de Bellas Artes, em Santiago. Em 1904 partiu para Paris. Em Montparnasse, fez amizade com grandes nomes das artes. Estudou na École des Beaux-Arts, em Paris.

${ }^{22}$ Ardengo Soffici (1879-1964) foi escritor, pintor e fascista. Estudou na Accademia, em 1897, e na Scuola Libera del Nudo. Em 1900, mudou-se Paris, tornou-se familiar com Braque, Derain, Picasso, Gris e Apollinaire.
} 


\subsection{A vida em Paris}

Modigliani havia se tornado um belo rapaz, como podemos constatar na Figura 6. "Em 1906, Modigliani decide continuar sua pesquisa em Paris. Paletó de veludo no estilo da Maremma - famosa área da Toscana à beira-mar, perto de Grosseto -, lenço vermelho...” (PARISOT, 2008, p. 40). Ele passou a morar em Paris, quando estava com 22 anos o que só foi possível pela ajuda financeira de sua família. Seu tio, irmão de sua mãe, Amédée Garsin, enriquecera com transações imobiliárias e comerciais e o auxiliou até seu falecimento, em 1905. A princípio, ele morou em hotéis mas, posteriormente, instalou-se num estúdio em Montmartre ${ }^{23}$, frequentou a Académie Colarossi $^{24}$ e conheceu o pintor Maurice Utrillo ${ }^{25}$, um amigo que manteve por toda a vida.

\footnotetext{
${ }^{23}$ Montmartre é um bairro boêmio da cidade de Paris, na França.

${ }^{24}$ A Académie Colarossi foi uma escola de artes parisiense em atividade entre 1815 e 1930. Fundada em 1815, foi adquirida alguns anos mais tarde pelo escultor italiano Filippo Colarossi (1841-1906). Funcionou no início na Île de la Cité e, posteriormente, na Rue de la Grande-Chaumière, Montparnasse, a pouca distância da Académie de la Grande Chaumière. Simultaneamente, escola privada e ateliê livre, a Academia era uma alternativa à École des Beaux-Arts, que se tornara muito conservadora aos olhos de muitos artistas. Assim como a Académie Julian, a escola de Colarossi também aceitava os estudantes do sexo feminino e lhes permitia pintar modelos masculinos nus (KRYSTOF, 2009).

${ }^{25}$ Maurice Utrillo (1883-1955) foi um pintor francês, filho da pintora Suzanne Valadon (1865-1938), que aprendeu a desenhar e a pintar com sua própria mãe. A partir de 1903, dedicou-se inteiramente à arte.
} 
Figura 6: “Amedeo Modigliani”, 1906, Itália, fotografia

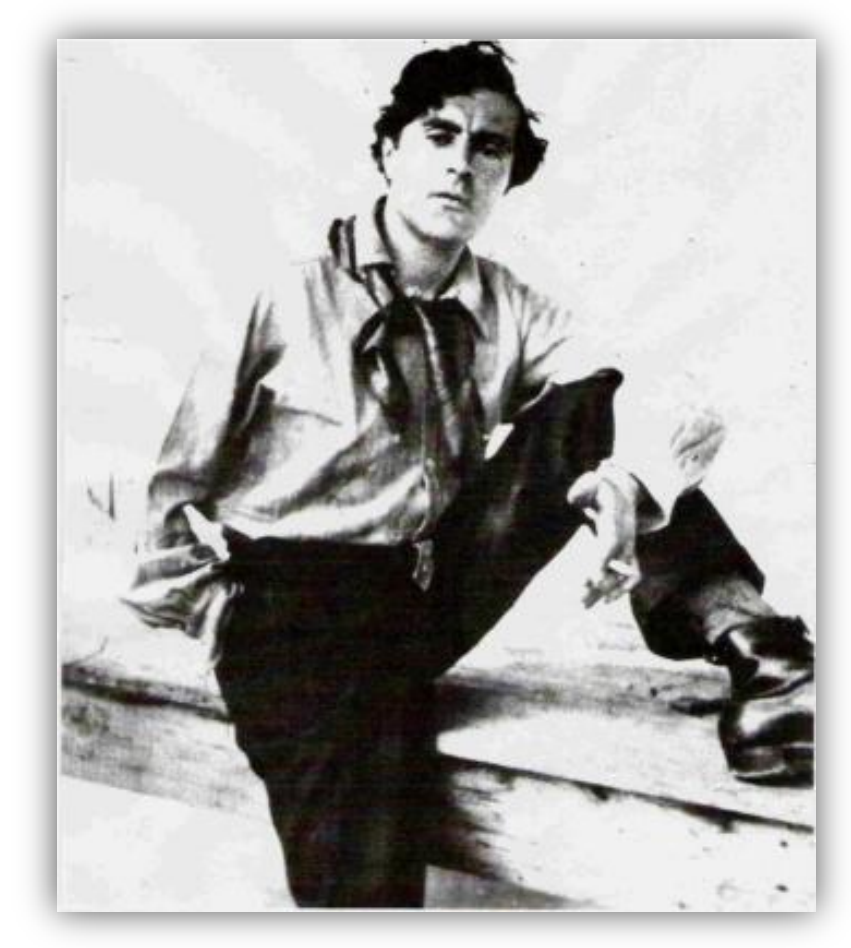

Fonte: PARISOT, 2006, p. 65.

"O último boêmio autêntico", era assim que o pintor alemão Ludwig Meidner $^{26}$, com quem Modigliani trocou conhecimentos no outono, o descrevia. Modigliani chegou no momento da avant-garde ${ }^{27}$, quando se buscava um novo ideal social, político, científico e artístico, que rompesse com o tradicional, em busca do experimentalismo, capaz de subverter o senso comum e de criar inovações, modificando o futuro. Essas novas propostas, claramente incompreendidas, apresentavam novas tendências e modificavam o contexto histórico. Essas novas atitudes apresentaram-se na literatura, na arquitetura, na música e nas artes plásticas e provocaram rupturas por toda Europa, com a liberdade de expressão e bases

\footnotetext{
${ }^{26}$ Ludwig Meidner (1884-1966) foi um pintor expressionista alemão, adscrito à Nova Objetividade.

${ }^{27}$ Avant-garde é um termo francês utilizado inicialmente pelos militares que originalmente significava "o que marcha à frente" e foi incorporado pelas artes plásticas significando propostas artísticas de inovação.
} 
caminhando em torno da subjetividade e do irracionalismo desconhecidos (FRANCK, 2015).

Esse momento político-econômico na França pertenceu à assim chamada Escola do Laissez-faire ${ }^{28}$, expressão-símbolo do liberalismo econômico, na versão mais pura de Capitalismo, mercado-livre dominante nos Estados Unidos e nos países ricos da Europa, durante o final do século XIX até o início do século XX. Passando por diversas mudanças políticas, a França chegou ao século XX com várias transições e diferentes regimes políticos. No final do século XIX e início do XX, a França desenvolveu uma constante em Ciência, Medicina, Arquitetura e, principalmente, nas Artes, sobretudo nas Artes plásticas. Modigliani encontrou o que precisava: o efervescer da cultura artística.

Quando Modigliani chegou à França, em 1906, ainda irradiava o caso Dreyfus ${ }^{29}$, e ele resolveu enfrentar este momento xenófobo. Ao se apresentar ao público, no aperto de mãos dizia: "Sou Modigliani, judeu!" (PARISOT, 2006), o que não fazia em Livorno, pois, estava totalmente seguro quanto ao seu meio, sua tradição judaica/sefardita.

Na história da França, os judeus foram marcados por períodos de perseguição, expulsão e restrição de liberdade, ficando isentos de direitos. Após a Revolução de 1789, ocorreu uma mudança, culminando com a nova Constituição, que emancipou a população judaica, diferentemente do que vigorava no Antigo Regime, no qual os judeus não existiam oficialmente. Em 1791, os judeus passaram a ser considerados “cidadãos franceses israelitas ${ }^{30 "}$.

\footnotetext{
${ }^{28}$ Laissez-faire é parte da expressão idiomática francesa "laissez faire, laissez aller, laissez passer", que significa literalmente "deixai fazer, deixai ir, deixai passar".

${ }^{29}$ O Caso Dreyfus (em francês: Affaire Dreyfus) foi um escândalo político que dividiu a França por muitos anos em função da questão da condenação por alta traição de Alfred Dreyfus (1859-1935) em 1894, um oficial de artilharia do exército francês, de origem judaica. Ele sofreu um processo fraudulento e a farsa foi acobertada por uma onda de nacionalismo e xenofobia que invadiu a Europa no final do século XIX.

${ }^{30}$ Israelita significa advindo do reino hebreu de Israel (1020-922 a. C.), formado da união de tribos.
} 
Napoleão Bonaparte pretendeu impulsionar e emancipar as comunidades judaicas na vida francesa, possibilitando sua integração à nação. Reorganizou a Igreja Católica e a Protestante, mantendo-as sob o controle do Estado e tentou reorganizar os assuntos judaicos de maneira semelhante. Como parte desse processo, convocou uma “Assembleia dos Judeus Notáveis” e, em 1807, um “Grande Sinédrio 31", composto por rabinos e intelectuais leigos.

Em 1808, após o "Grande Sinédrio", um edito estabeleceu um sistema de consistórios: juntas de rabinos e leigos para administrar os assuntos judaicos; manter e gerir as sinagogas e outras instituições religiosas; zelar por sua ordem; fiscalizar a aplicação dos decretos e se encarregar da distribuição de impostos. Em oito de fevereiro de 1831 o culto israelita recebeu um orçamento do Estado, se equiparando às outras religiões.

No fim do século XIX, surgiram as sinagogas criadas por mecenas judeus. Arquitetos judeus, como Aldrophe, Ulmann, Poutremoli, Bechmann e Hess projetaram os templos. Os Rothschild financiaram a construção das sinagogas de Paris e as das províncias de Boulogne, Neuilly e Chasseloup. Famílias abastadas as adornaram com objetos preciosos como candelabros, mantos de Torá e fino mobiliário. A família Heine, responsabilizou-se pela construção da sinagoga de Versalhes. O banqueiro Daniel Iffla, financiou a construção do templo de rito sefardita em Paris, na Rue Buffault (1877), em Arcachon (1879), em Bruyères (1903). Famílias sefarditas como os Allegri, Astruc, Sciama e Paz também contribuíram para a construção de sinagogas.

Modigliani compreendia as tradições que sua mãe e, principalmente, seu avô Isacco lhe ensinaram, porém, nesse período de estadia em Paris, sua busca foi por um conteúdo muito mais ligado às artes do que às tradições. Contudo, por ser judeu e

\footnotetext{
${ }^{31}$ O termo sinédrio significa assembleia ou conselho de anfitriões na Palestina, sob o domínio romano; assembleia judia de anciãos da classe dominante às quais diversas funções políticas, religiosas, legislativas, jurisdicionais e educacionais foram atribuídas.
} 
artista, a apropriação de suas obras teve no suporte anímico um estado de plenitude de religação à sua tradição.

Seus amigos próximos e colegas também eram judeus e sua arte cumpria de certo modo o papel da Sinagoga. Seu templo era formado por suas telas; seu simbolismo religioso habitava no universo contido em suas obras; seus pincéis e suas lapidações transmitiam a fala de $D^{\prime} u s$.

Seu círculo de relacionamentos cresceu. O artista Auguste Henri Doucet ${ }^{32}$ apresentou Modigliani ao jovem médico Dr. Paul Alexandre (1881-1968) que, juntamente com seu irmão Jean, alugou um estúdio para apoiar jovens artistas. Paul Alexandre tornou-se o primeiro patrono de Modigliani e comprador de alguns desenhos. Por intermédio dele, Modigliani conseguiu encomendas de retratos.

Modigliani teve algumas obras expostas no Salon d'Automne ${ }^{33}$, de 1907. Suas obras, nesse período, apresentavam influências Simbolistas. Ele conheceu as obras na retrospectiva de Paul Cézanne e foi profundamente influenciado pelo artista. Também teve contato com as obras de Edvard Munch (1863-1944) e Toulouse-Lautrec (18641901). Modigliani registrou-se na Sociedade dos Artistas Independentes.

Montmartre e Montparnasse, dois bairros próximos e boêmios de Paris, foram fundamentais na vida e na obra de Amedeo Modigliani. Ao transitar pela vida destes bairros, Modigliani passou a conhecer artistas de vanguarda, como: Picasso (18811973), Juan Gris (1887-1927), Van Dongen (1877-1968), Chaim Soutine (1893-1943); e

\footnotetext{
${ }^{32}$ Henri Auguste Doucet (1883-1915) foi um desenhista e pintor francês.

${ }^{33}$ Salon d'automne era o Salão do Outono criado por inciativa do arquiteto belga Frantz Jourdain (18471935), presidente do sindicato dos críticos de arte. A primeira edição foi aberta ao público em 31 de outubro de 1903, no Petit Palais, espaço de divulgação oferecido a jovens artistas. A escolha do Outono era intencional, pois não só permitia aos artistas apresentar os pequenos formatos realizados no exterior durante o verão, como também demarcava os dois outros grandes salões da época - o da Société Nationale des Beaux-Arts e o Salon des artistes françaises - ambos realizados durante a primavera. O salão distinguia-se pela sua multidisciplinaridade (LACLOTTE, 1997).
} 
escritores como: Guillaume Apollinaire (1880-1918), Max Jacob (1876-1944) dentre muitos outros.

Montmartre, como mencionamos, é um bairro boêmio de Paris. O terreno tem forma de colina e no tempo dos gauleses (III a. C.) foi um lugar de culto. Em torno do ano 250 d. C. inúmeros cristãos foram torturados nessa colina consagrada a São Dionísio $^{34}$, tornando-se mais tarde um local de peregrinação. No ano de 1133, o Monte foi organizado por monges beneditinos que ali cultivavam uvas.

Por sua posição estratégica, quando necessário, Montmartre foi centro de comandos militares. No ponto mais alto dessa colina, situa-se a famosa Basilique de Sacre Coeur de Montmartre, monumento edificado no final do século XIX, em estilo romano-bizantino. A partir de 1860, o bairro foi se transformando em um ponto de encontro importante de artistas e intelectuais e foi ligado à cidade de Paris, tornando-se famoso pela sua vida noturna, com seus cabarés transformados em cafés literários. $\mathrm{O}$ clima libertário surgiu com os animados artistas, que não se esqueceram das origens do local, com o cultivo do vinho e a consagração a Dionísio.

Montparnasse segue a mesma linha de empolgada vida noturna. É um bairro localizado à esquerda do rio Sena e seu nome é uma referência à montanha grega considerada, na mitologia clássica, residência do deus Apolo e de suas nove Musas, de onde deriva a palavra museu.

Ambos os bairros, Montmartre e Montparnasse, se converteram em locais apropriados para o desenvolvimento do espírito artístico devido ao seu conteúdo histórico e à associação ao consumo etílico. Como mencionamos anteriormente, foi neste ambiente que Modigliani viveu e produziu boa parte de sua arte, embora tenha mudado de residência com muita frequência.

\footnotetext{
${ }^{34} \mathrm{Na}$ antiga religião grega, Dionísio é o deus dos ciclos vitais, das festas e do vinho.
} 
Em 1908, Modigliani expôs seis telas no Salon des Indépendants ${ }^{35}$, incluindo, dentre elas, “A Judia” (Figura 33) que será analisada no terceiro capítulo.

Sua primeira encomenda importante foi feita pela Baronesa Marguerite de Hasse de Villers e resultou na obra intitulada “A Amazona” (Figura 7), de 1909. Trata-se de um retrato elaborado na primavera, quando Modigliani morava em Montparnasse e tinha um estúdio na Cité Falguière. Ao olhar o quadro, a Baronesa não gostou da representação e recusou sua encomenda. Este fato pode, inclusive, ter influenciado Modigliani a se direcionar para a escultura.

Figura 7: Modigliani - "A Amazona", 1909, ost, 92 x 65 cm, coleção particular

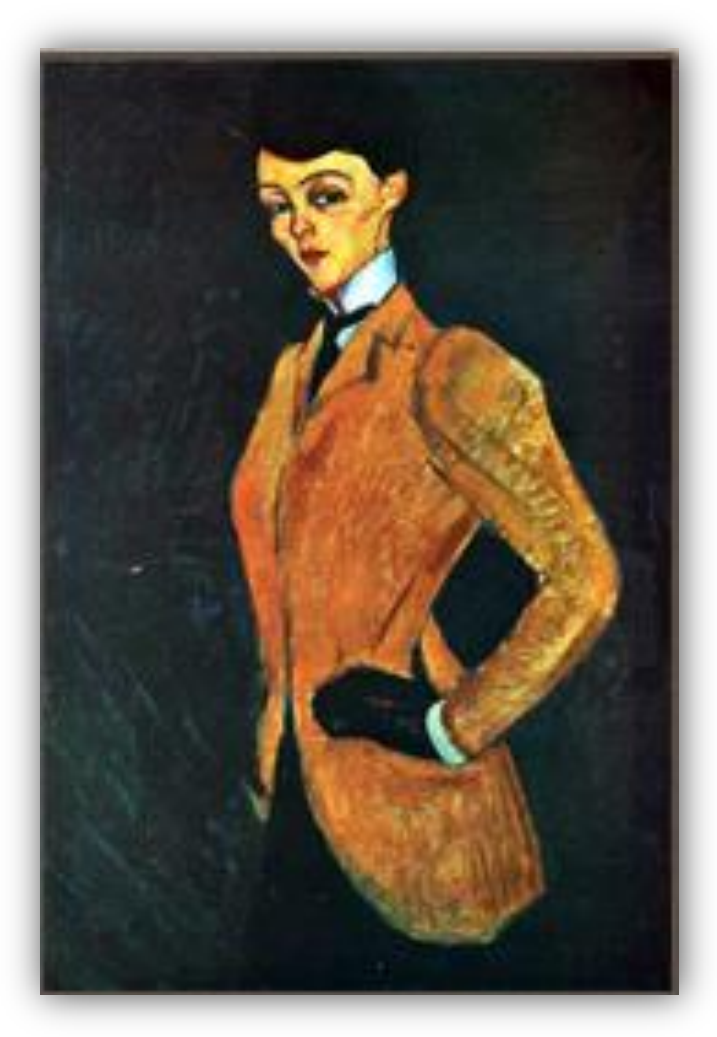

Fonte: GALLAND, 2005, p. 43.

\footnotetext{
35 Salon des Indépendants, Salão dos Independentes, foi criada em 1884 por artistas que desejavam expor o seu trabalho livremente da influência de qualquer júri.
} 


\subsection{O Escultor}

Modigliani conheceu o escultor romeno Constantin Brancusi (1876-1957), por intermédio de Paul Alexandre. Brancusi lhe mostrou o caminho da escultura, o que levou Modigliani a dedicar sua arte a esta técnica, de 1909 a 1914, quase não pintando neste período. Seu suporte era a pedra do meio-fio ${ }^{36}$.

Em 1909, Modigliani passou o verão na Itália com a família, recuperando sua saúde sempre frágil. No ano seguinte, em 1910 se tornou amigo do escritor Max Jacob ${ }^{37}$ e se envolveu amorosamente com Anna Achmatova ${ }^{38}$, poetisa russa.

Em 1911, Modigliani expôs as pedras $\operatorname{arcaizantes}^{39}$ no estúdio do artista português Amadeu de Sousa Cardoso ${ }^{40}$. Era um trabalho de escultura sobre as cariátides, chamado de "colunas de ternura", como podemos observar no desenho (Figura 8) e na pedra calcária (Figura 9) a seguir expostos.

\footnotetext{
${ }^{36}$ Meio-fio é a borda ao longo da rua; é a beira da calçada, também conhecida em São Paulo como sarjeta (Figura 35).

${ }^{37}$ Max Jacob (1876-1944) foi um poeta, pintor, escritor e crítico judeu-francês, influente no período surrealista. Ao presenciar uma aparição do Cristo em seu quarto, converteu-se ao catolicismo. Seu padrinho de batismo foi Pablo Picasso.

${ }^{38}$ Anna Akhmatova (1889-1966) é o pseudônimo de Anna Andreevna Gorenko, poeta acmeístas que começou a escrever poesias aos onze anos de idade. Estudou no liceu feminino de Tsarskoe Selo, no célebre Instituto Smolnyi de São Petersburgo, e no Liceu Fundukleevskaia de Kiev.

${ }^{39}$ Arcaizantes é o que ou aquele que, na linguagem escrita ou falada, emprega ou tende a empregar arcaísmos, arcaísta, escritas em segredo.

${ }^{40}$ Amadeo de Souza-Cardoso (1887-1918) foi um pintor português, precursor da arte moderna, da vanguarda. Frequentou o curso de Arquitetura na Academia de Belas Artes de Lisboa, em 1905, interrompendo-o para partir para Montparnasse, em 1906, para se dedicar exclusivamente à pintura.
} 
Figura 8: Modigliani - "Cariátide", 1913, tsc, 34 x $23 \mathrm{~cm}$, coleção particular

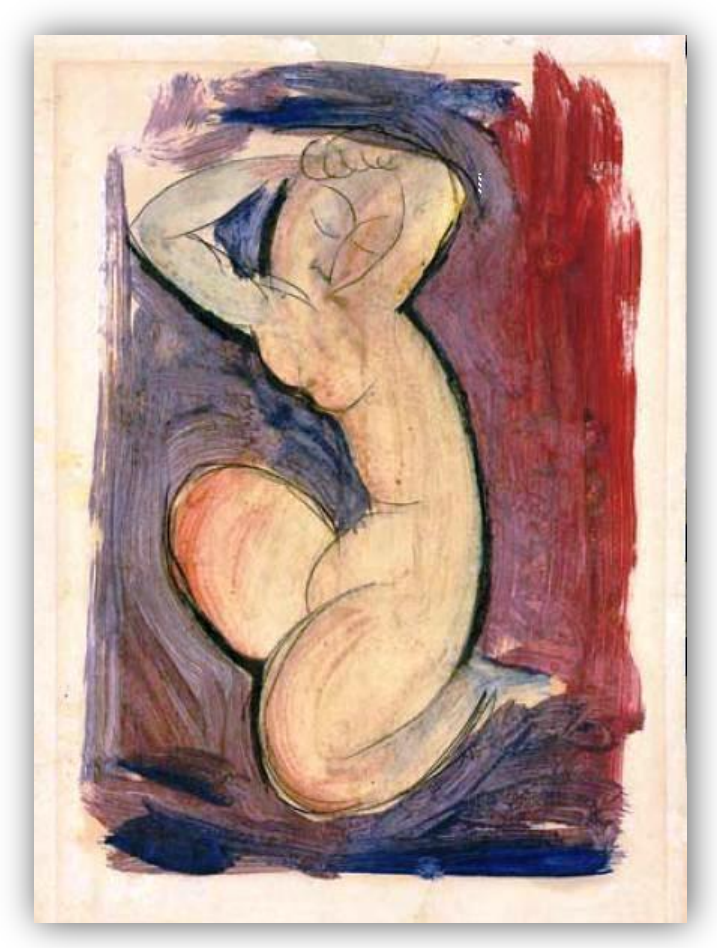

Fonte: PARISOT, 2010, p. 156.

Figura 9: Modigliani - "Cariátide", 1914, pedra calcária, 92 x 41 x 42,9 cm, MOMA

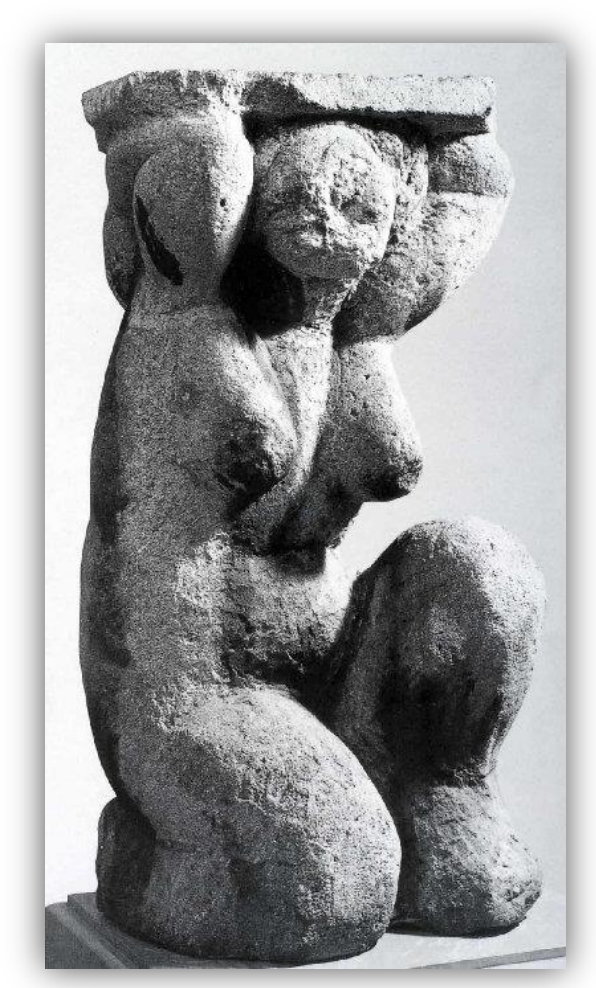

Fonte: GALLAND, 2005, p. 68. 
Em 1912, Modigliani conviveu os escultures judeus Jacques Lipchitz ${ }^{41}$ e Jacob Epstein $^{42}$ e expôs oito esculturas no Salon d'Automne. Augustus John ${ }^{43}$, pintor inglês, adquiriu uma delas. Modigliani voltou a viver em Montmartre, na Passage de l'Elysée des Beaux-Arts. Logo a seguir, por intermédio de Max Jacob, conheceu seu novo caso amoroso que Beatrice Hastings (1879-1943), que retratou em 1916 (Figura 10).

Figura 10: Modigliani - "Beatrice Hastings", 1916, ost, 55 x 38 cm, Barnes Fundation EUA

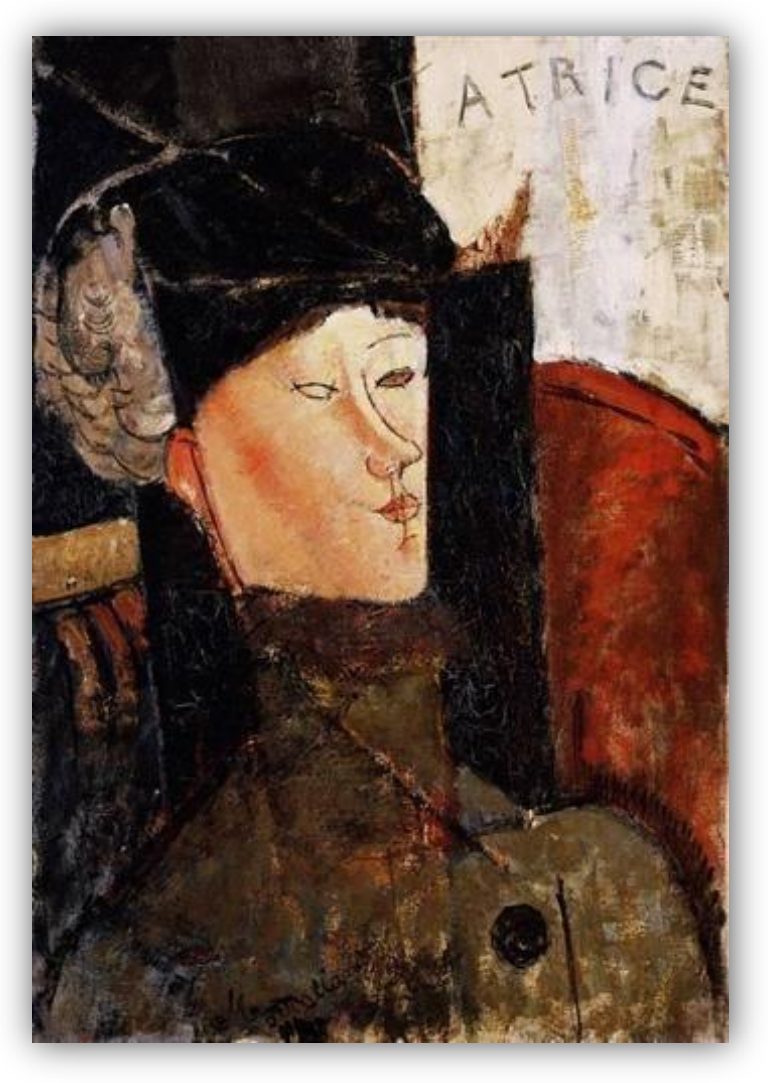

Fonte: NICOSIA, 2011, p. 80.

\footnotetext{
41 Jacques Lipchitz (1891-1973) foi um escultor cubista Lituano. Lipchitz nasceu em Chaim Lipchitz Jacob, filho de um empreiteiro em Druskininkai, Lituânia, Império Russo. Sob influência de seu pai, ele estudou Engenharia, mas logo a seguir, apoiado por sua mãe, mudou-se para Paris (1909), para estudar na École des Beaux-Arts e na Académie Julian.

${ }^{42}$ Jacob Epstein (1880-1959) foi um escultor de origem judeu-russo, que foi para Paris em 1902 e em 1905 acabou fixando residência em Londres. Durante sua estada em Paris estudou a obra de Picasso, de Brancusi, de Rodin e de Modigliani.

43 Augustus Edwin John (1878-1961) foi um pintor e gravurista gaulês. Estudou na Academia de Liverpool e na Escola de Arte de Londres com Ford Madox Brown (1821-1893). O primeiro trabalho de sua carreira como artista foi inspirado em Rembrandt. A maioria de suas obras foram retratos, caracterizados por uma grande vitalidade e uma profunda análise psicológica (LACLOTTE, 1997).
} 
Beatrice Hastings era o pseudônimo de Emily Alice Haigh. Ela foi uma personagem interessante, excêntrica escritora inglesa, poeta e crítica literária, com quem Modigliani teve um relacionamento que durou dois anos, numa tempestuosa ligação. Ela foi a modelo preferida nos retratos de Modigliani, que a pintou oito vezes. Hastings era bissexual, amante da contista Katherine Mansfield (1888-1923). Hastings foi também amante do pintor inglês Wyndham Lewis (1882-1957). Modigliani passou a morar no apartamento dela, na Rue Norvain, na Butte Montmartre. Hastings terminou pondo fim em sua vida, com o gás de um fogão doméstico, por se sentir excluída do mundo literário, em 1943 na Grã-Bretanha.

Em 1913, Modigliani foi para Livorno e, nesta sua estada na cidade, vivenciou momentos desagradáveis, pois seus amigos estavam vivendo um momento já ultrapassado na cultura artística (GOMBRICH, 1978). Em seu retorno a Paris aproximou-se mais de um conteúdo artístico, baseado em pesquisa mais elaborada, pois sentiu a diferença ou a indiferença dos patrícios em sua cidade natal. Em carta direcionada a Paul Alexandre ele relata que estava esculpindo em mármore (PARISOT, 2006, p. 45).

\subsection{O Pintor}

De 1914 a 1918 ocorreu a Primeira Guerra Mundial. Modigliani tentou se alistar mas, devido à fragilidade de sua saúde, foi considerado inapto. Passou, então, por um período bastante difícil mas, durante este tempo, forjou sua técnica, abandonou a escultura e reconheceu sua essência sintética na pintura. Paul Alexandre foi para as armas, e a partir de então, cada qual passou a seguir sua própria vida. 
Em 1914, Modigliani conheceu o galerista Paul Guillaume ${ }^{44}$, graças a Max Jacob e, em 1915, o retratou (Figura 11). Guillaume incluiu Modigliani em várias exposições coletivas ocorridas em seu estabelecimento. Em Londres, Guillaume incluiu suas obras na Whitechapel Gallery ${ }^{45}$.

Figura 11: Modigliani - "Paul Guillaume", 1915, ost, 105 x $75 \mathrm{~cm}$, Museu de L’Orangerie

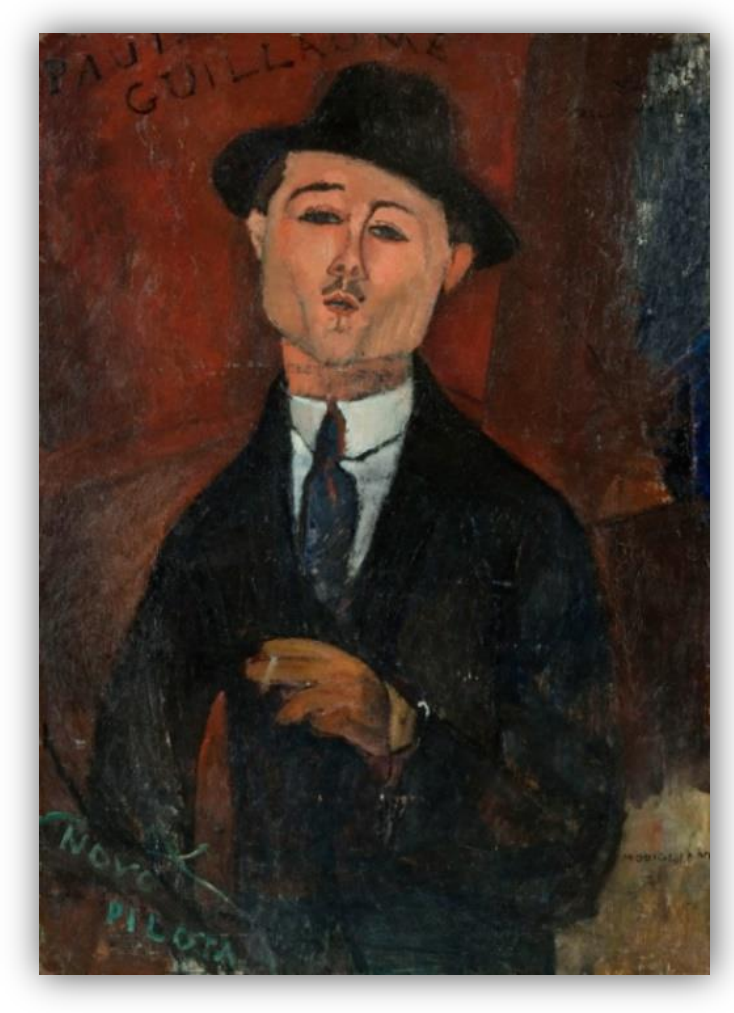

Fonte: GALLAND, 2005, p. 101.

Modigliani viveu no período conhecido como Moderna Escola de Paris, grupo de artistas reconhecidos por uma vida excêntrica, desregrada, marginal nas artes plásticas. Seu ápice foi entre 1905 e 1913, quando artistas estrangeiros frequentavam e

${ }^{44}$ Paul Guillaume (1891-1934) foi um negociante de arte francês. Comerciante de Modigliani e de Chaim Soutine, foi um dos primeiros a organizar exposições de arte africana. Também negociava obras de artistas já reconhecidos, tais como: Henri Matisse, Constantin Brancusi, Pablo Picasso e Giorgio de Chirico.

${ }^{45}$ A Galeria Whitechapel foi uma galeria de arte pública no lado norte de Whitechapel High Street, no bairro londrino de Tower Hamlets. Desenhada pelo arquiteto Charles Harrison Townsend (1851-1928), foi inaugurada em 1901 como uma das primeiras galerias de financiamento público para exposições temporárias. 
moravam em Montmartre e em Montparnasse. A Figura 12 retrata Modigliani em 1915, em seu estúdio.

Figura 12: "Modigliani em seu estúdio", 1915, França, fotografia de Paul Guillaume

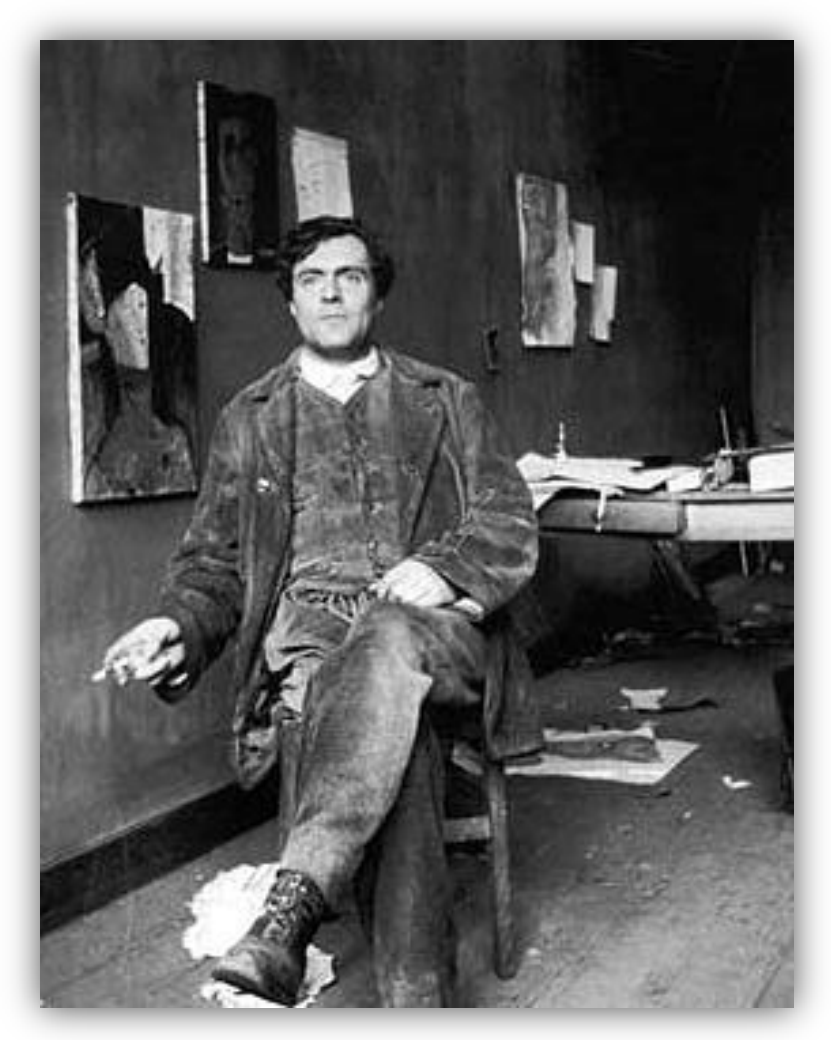

Fonte: GALLAND, 2005, p. 12

A deflagração da Primeira Grande Guerra trouxe dor, miséria e morte; gerou perdas e uma nova hegemonia. O conflito empreendeu uma quebra de paradigmas que modificou valores. O mundo foi modificado, o processo hierárquico civilizatório atuou com nova tomada de compreensões. A ruptura com o Velho Mundo deu lugar ao início de um progresso, carregado da nova ciência, da modernidade, do racionalismo e de uma Nova Ordem (LEITE, 2011).

Surgiram novas discussões da imagem e da questão da reprodução. Surgiram debates sobre o significado de uma obra a partir da instalação da "Roda de bicicleta" do 
artista plástico Marcel Duchamp (1887-1968), que trouxe, sem dúvida, a oportunidade para a incorporação dessas novas impressões.

A harmonia e a beleza deram lugar à complexidade e à estranheza, à absorção da obra de arte num mundo marcado pelo trauma da guerra e da morte. Isso destaca e coloca diante dos olhos da humanidade o provocar da nova arte, na qual os padrões cedem e é atribuído um sentido crítico ao presente, sugerindo a procura de novas formas (MAILLARD, 1981).

Em 12 de agosto de 1916 Jean Cocteau $^{46}$ tirou uma série de fotografias, com Picasso, Max Jacob, André Salmon ${ }^{47}$, Ortiz de Zarate e Moïse Kisling ${ }^{48}$ (Figura 13).

Figura 13: "Modigliani, Max Jacob, André Salmon e Zarate", 1916, fotografia

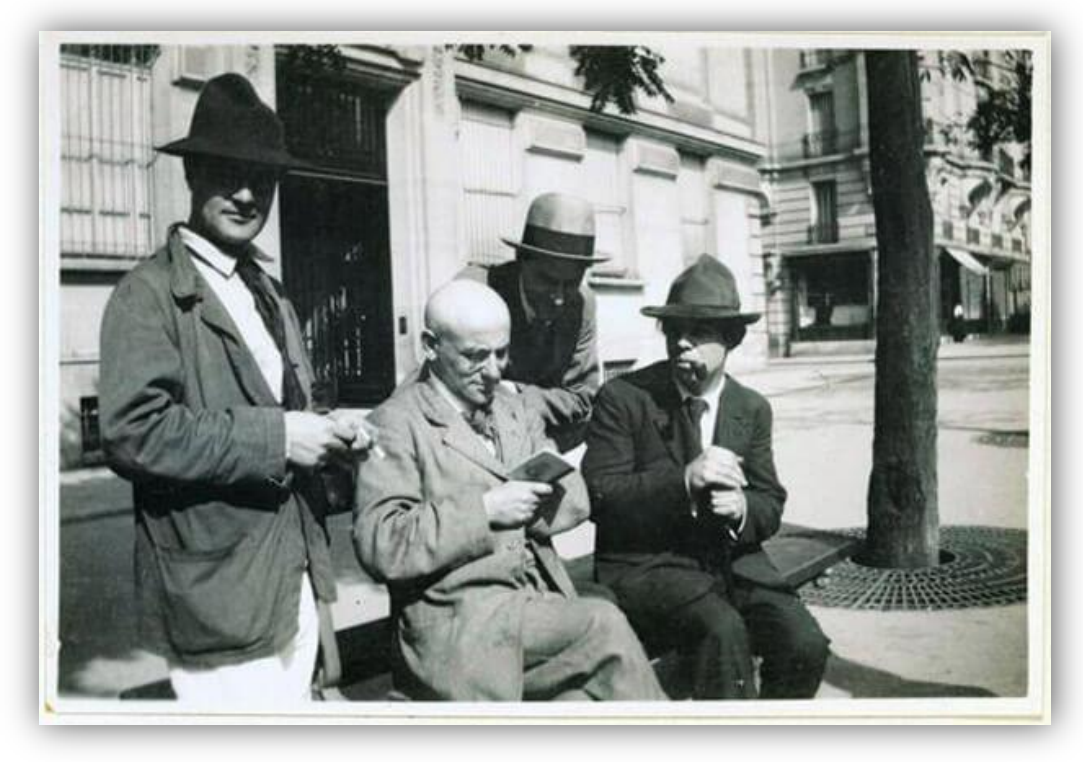

Fonte: PARISOT, 2010, p. 207.

\footnotetext{
${ }^{46}$ Jean Cocteau (1889-1963) foi um poeta, romancista, cineasta, ator, designer e escultor.

47 André Salmon (1881-1969) foi um poeta, escritor e crítico de arte francês, defensor do cubismo. Era amigo íntimo de Guillaume Apollinaire (1880-1918), importante escritor e crítico de arte.

${ }^{48}$ Moïse Kisling (1891-1953) foi um pintor francês de origem polonesa e ascendência judaica, de estilo expressionista. Pertenceu à chamada Moderna Escola de Paris, nas primeiras décadas do século XX.
} 
O conteúdo artístico das obras de Modigliani é figurativo, com influências do fauvismo e do expressionismo, com extrema valorização das cores. Seus elementos plásticos trazem a inovação com lucidez, um desencantamento pelo mundo, pelo drama e pela tragédia. Artistas da Moderna Escola de Paris foram: Marc Chagall (1887-1985), Chaim Soutine (1894-1943), Moïse Kisling (1891-1920), Jules Pascin (1885-1930), Tsuguharu Toujita (1886-1968) entre outros. Nas obras de Soutine, encontramos configurações delirantes e expressivas, tintas violentamente projetadas, formando saturações contrastantes. Nas obras de Chagall, que se desenvolvia no universo onírico, encontramos símbolos enigmáticos e místicos, nos quais a metáfora relata sua vida.

As características da obra de Modigliani estão ligadas e relacionadas com a figuração humana, com nus sensuais e elegantes, sendo sua estilização de extrema liberdade, embora tenha sido considerado obsceno para o período. Alguns críticos o classificam como pintor expressionista, o que será discutido mais a diante neste trabalho.

O período de Boemia $^{49}$ vivido por Modigliani teve este epíteto, porque ele resistia contra o estabelecido e contra a conservadora burguesia, buscando uma atmosfera de liberalidade religiosa, sexual e, principalmente, pessoal. A Paris boêmia, efervescente, é a dos anos 1900-1930 e apresentou a vida de personagens, mostrando relacionamentos puramente livres, nos quais o individual soma-se ao outro em uma revolução estética. Foi esta a vivência artística de Montmartre e Montparnasse, jamais vista noutros lugares do mundo. Nestes bairros, pessoas de nacionalidades diversas, artistas e marginais, ofícios, gêneros, estilos e personalidades encontravam abrigo para trabalhar e viver. Pintores, escultores, escritores e poetas, figuras inclassificáveis, todos

\footnotetext{
49 Boemia é uma palavra de origem francesa, que designa o habitante da Boêmia e do topônimo latino medieval Bohemus (povo celta da Europa central). No século XV, bohème era um termo comum, utilizado para os ciganos na França, que vieram da Boêmia. No século XVII, com Gédéon Tallemant des Réaux, a expressão bohème passou a designar também o indivíduo "que leva uma vida desregrada".
} 
imbuídos de uma paixão inovadora e renovada, com sede de uma nova estética, mas com pouco ou nenhum dinheiro.

Modigliani também foi envolvido pela Belle Époque ${ }^{50}$ com suas novas invenções que modificavam a vida em todos os níveis sociais e traziam efervescência à cena cultural, aos cabarés, ao cancã ${ }^{51}$. O cinema surgiu e a arte tomou as novas formas do Art Nouveau ${ }^{52}$. A vida na alta burguesia e na aristocracia era despreocupada, cheia de luxos e prazeres sofisticados.

Em 1916, Modigliani conheceu Leopold Zborowski ${ }^{53}$, polonês, poeta, escritor, negociante de arte que se tornou seu marchand, organizador de suas exposições, amigo e protetor até a morte. Modigliani pintou três retratos deste amigo, um deles será comentado no terceiro capítulo deste trabalho.

Ainda em 1916, Modigliani conheceu Simone Thiroux (1892-1921) (Figura 14), uma estudante canadense com problemas nos pulmões que foi a Paris para esquecer sua doença e tentar viver intensamente. Ela se apaixonou por Modigliani e este amor gerou uma criança, Géral Thiroux (1917-2004), filho nunca reconhecido por Modigliani.

\footnotetext{
${ }^{50}$ Belle Époque foi a fase de euforia e despreocupação vivida na Europa, entre 1871, com o final da guerra franco-prussiana, e 1914, com o início da Primeira Guerra Mundial. Caracteriza-se, basicamente, por grande produção artística, literária e bom desenvolvimento tecnológico.

${ }^{51}$ Cancã é uma palavra de origem francesa - cancan - criada em 1829. É a reduplicação da primeira sílaba de "canard" (que significa 'pato'), utilizada para caracterizar um estilo de dança que se parece com $o$ andar desse animal.

${ }^{52}$ Art nouveau ou Arte Nova é, basicamente, um estilo internacional de arquitetura e de artes decorativas - início da arte aplicada à indústria - que foi muito apreciado de 1890 até os anos 1920. Modigliani também conviveu com o movimento artístico Art Déco (Arte Decorativa) (1910-1939).

${ }^{53}$ Léopold Zborowski (1889-1932) foi o primeiro comerciante de arte de René Iché, Chaim Soutine, Maurice Utrillo, Émile Savitry, Marc Chagall e André Derain. Dos três retratos dele feitos por Modigliani, um foi vendido por US\$ 1.464 .000 na Sotheby's, em 2003.
} 
Figura 14: Modigliani - "Simone Thiroux", 1916/18, ost, 73 x 50 cm, coleção Olga Sidamon-Eristavi

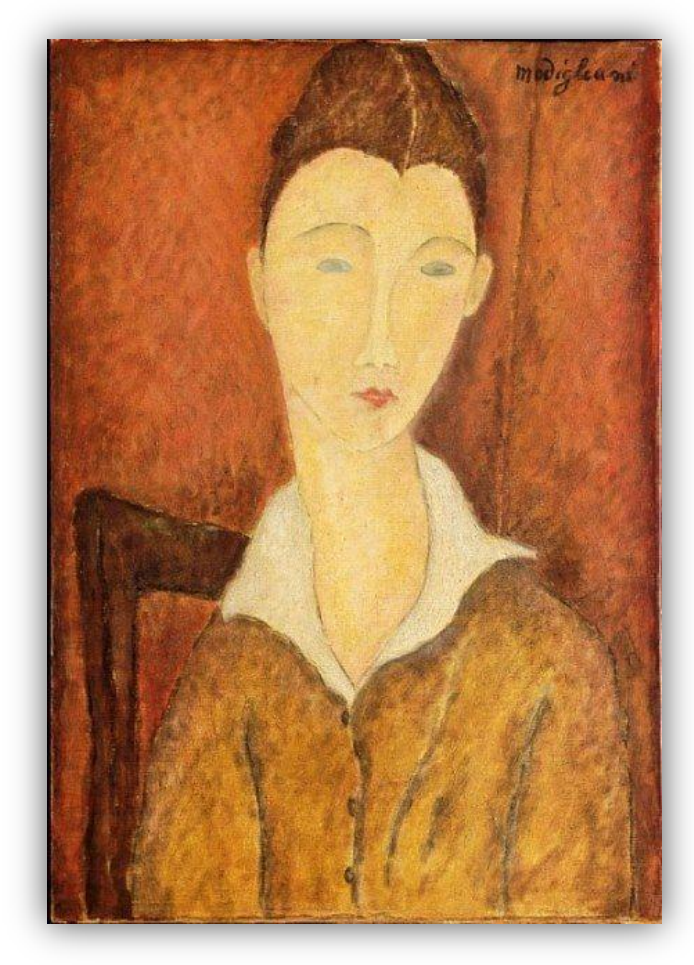

Fonte: RIPOSATI, 2009, p. 23.

Modigliani foi um homem fascinante, que não buscava uma vida de conduta, mas uma vida de sedutor e sedução pela arte de viver. Seu mundo, a França pós-virada do século, centro da arte no mundo, foi onde procurou a liberdade para pensar e realizar. Mais do que tudo, Modigliani foi um dos "malditos"! Peintre maudit (pintor maldito) era o apelido de Modigliani entre seus amigos. Ele era diferente, pois era um pensador, refletia sobre sua existência e tinha necessidades diferentes das dos seres humanos considerados "comuns". Para ele, os artistas detinham buscas diferenciadas, o que o levou à leitura de autores também malditos, como Friedrich Nietsche (18441900), Charles Baudelaire (1821-1867) e Henri Bergson (1859-1941). Construiu e se destruiu, sua criação foi a devoção implacável ao consumo da vida.

Suas inúmeras ligações amorosas, a bebida, as drogas e a leitura destes pensadores completavam sua busca. Mas, qual busca? A busca pela criação plena. A 
arte como um mundo de representação, realizada em seus símbolos, o mundo sutil, o mundo do não palpável. Para Modigliani, o mundo místico.

A vida de Modigliani foi dramática e assombrosa. Suas obras transmitem o portento do milagre de existir. O artista é o que o desejo pede; é a potência criadora na qual suas experiências de vida são realizadas e, assim, suas obras tornam-se o prodígio do extraordinário.

Modigliani desenhava, esculpia e pintava sua vida. Suas representações plásticas eram suas libertinagens, embasadas por um conteúdo de sabedorias milenares. Ele compunha com seus pares o trago da noite e cada amigo era uma experiência de prazer dos sentidos.

Em dezembro de 1916, então com 32 anos, Modigliani, conheceu Jeanne Hébuterne, então com 18 anos, tendo sido apresentada a ele pelo irmão, André Hébuterne $^{54}$, artista de Montparnasse, pequeno sócio de Modigliani. Jeanne nasceu em seis de abril de 1898, filha de Achille Casimir Hébuterne, contabilista, e Eudoxie Anaïs Tellier, do lar, vindo de uma família católica conservadora. Ela foi a grande paixão de Modigliani. A diferença religiosa e etária, de 14 anos, bem como a oposição da família não comprometeram a paixão. O apelido de Jeanne Hébuterne era Coco, por ser muito branca. Ela foi representada por Modigliani em 1918, na singela tela reproduzida na Figura 15.

\footnotetext{
${ }^{54}$ André Hébuterne (1894-1992) foi um pintor francês que trabalhou durante muito tempo como retratista, tendo como seus modelos familiares e amigos. Teve limitado sucesso como artista, mas suas gravuras à água-forte, feitas para a impressão de 1948 do livro Gargantua foram baseadas na criação de François Rabelais. Foram elas que lhe deram mais fama.
} 
Figura 15: Modigliani - "Jeanne Hébuterne", 1918, ost, 46 x 29 cm, coleção particular

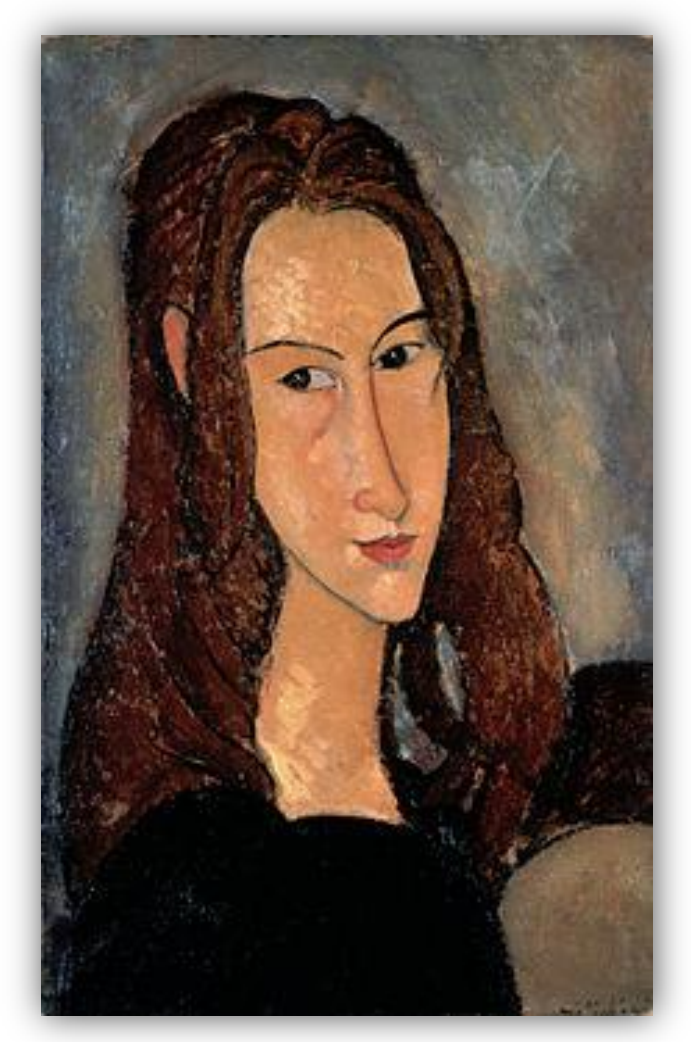

Fonte: GALLAND, 2005, p. 141

Por influência de seu irmão André, Jeanne se voltou para as artes, se relacionando com a comunidade artística de Montparnasse e estudando na Academia Colarossi. Ela compôs obras como "A suicida" e "A morte”, ambas trabalhos simples. Jeanne foi retratada diversas vezes pelo pintor janonês Tsuguharu Foujita ${ }^{55}$.

Em suas relações amorosas, Modigliani bebeu da expressividade carnal da alma, transmitindo a irradiação em seus nus, nos quais as formas eram o próprio corpo e as cores o sentir sensual do rubor quente da pele.

\footnotetext{
${ }^{55}$ Tsuguharu Foujita (1886-1968) foi um pintor modernista japonês que se naturalizou francês e se converteu ao catolicismo. Viveu no Rio de Janeiro de 1931 a 1932.
} 
Em 1917, Modigliani expôs na Galeria Berthe Weill ${ }^{56}$. Foi sua primeira exposição individual (Figura 16), que deveria ter ocorrido de 03 a 30 de dezembro, mas durou apenas duas horas. Sua mostra foi fechada pela polícia porque apresentava uma excessiva quantidade de nus femininos.

Figura 16: "Convite da primeira exposição individual de Modigliani”, 1917, França, fotografia

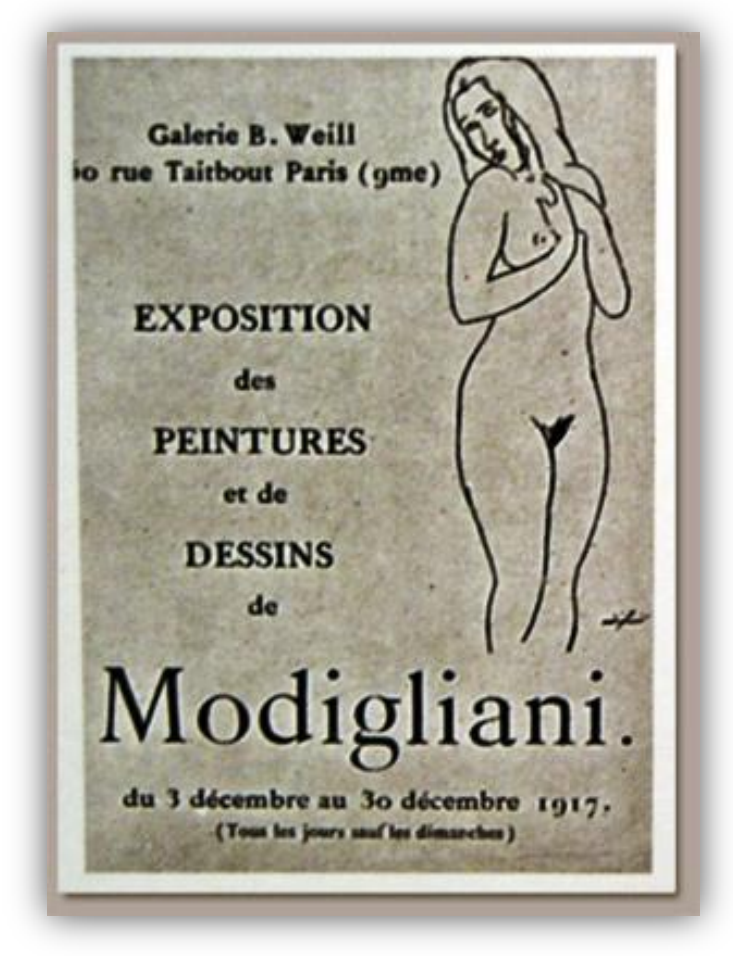

Fonte: PARISOT, 2006, p. 193

Este período de produção de Modigliani constituiu-se num marco da representação do nu feminino. Ele executou uma série deles. Mesmo com o estado de saúde fragilizado, foi inspirado pelo local, onde a luz fez surgir obras maiores e com tons vivos, e pelo reencontro com Soutine e Foujita. Suas trinta e duas obras formavam um grande fenômeno em sua pequena produção. Seu nu era referência ao estado de

\footnotetext{
${ }^{56}$ Ether Berthe Weill (1865-1951) foi uma notável negociante de arte francesa que contribuiu para a criação do mercado de arte no início do século XX e do avant-garde parisiense.
} 
alma, ou seja: não uma mulher sem roupa mas, uma mulher sem 'véus' (GALLAND, 2005).

Em seus nus deste período, Modigliani representou a pura sensualidade feminina característica da vida boemia parisiense. Podemos notar os pelos pubianos aparados em algumas das modelos, algo pouco comum para as mulheres nesta época. Modigliani retratou a plena sensualidade e a excitação devocional à volúpia e emoção corpórea, que vão contra o tradicional recato, em especial das judias sefarditas. O artista nestas obras parece abrir mão de suas origens judaicas em função da luxúria e da boemia que o impregnavam, bem como à maioria dos modernistas franceses. Já nos retratos, Modigliani foi bastante fiel ao simbolismo da tradição judaica, como veremos a partir do terceiro capítulo.

Com a ameaça de invasão pelos alemães, em 1918, Modigliani e Jeanne abandonam Paris na primavera. Em Nice, na costa mediterrânea, Modigliani produziu várias obras, retratos, vendidos por Zborowski em Paris. Em 29 de novembro de 1918, nasceu Jeanne Modigliani, a menina que no futuro, cuidaria das obras e do legado artístico do pai. Ainda neste ano, Paul Guillaume organizou uma exposição coletiva, na Galerie Faubourg Saint-Honnoré, em Paris, reunindo obras de Modigliani, Picasso e Matisse.

Em 1919, residindo na casa do pintor Andes Osterlind ${ }^{57}$, em Cagnes, Modigliani pintou a esposa de Andes, Rachele Osterlin (Figura 17) e pediu dinheiro emprestado para Zborowski para enviar suas telas concluídas a Paris.

\footnotetext{
${ }^{57}$ Anders Osterlind (1887-1960) foi um pintor francês, filho do pintor sueco Allan Osterlind (1855-1938).
} 
Figura 17: Modigliani - "Rachele Osterlin", 1919, osl, 46 x 33 cm, coleção particular

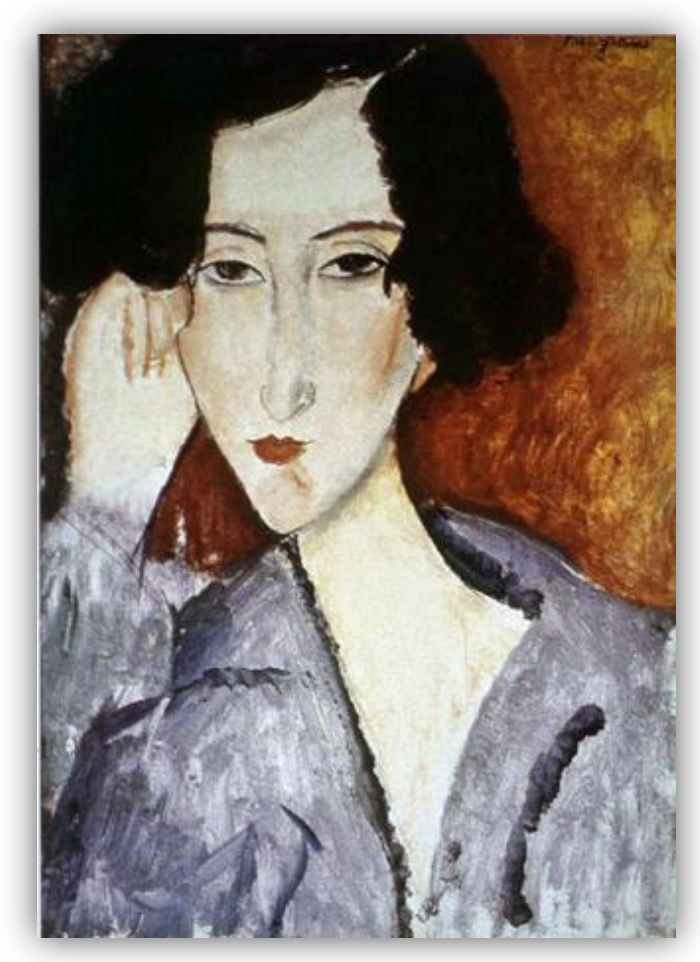

Fonte: PARISOT, 2010, p. 267

Zborowski colocou obras de Modigliani em várias exposições. Em 1919, por exemplo, Modigliani expôs na Galeria Mansard, em Heale, na Inglaterra (Figura 18); na exposição Modern French Art (Pintura Moderna Francesa), e também na Hill Gallery. Colecionistas ingleses adquiriram suas obras. Como negociante de arte de Modigliani, Zborowski acumulou uma pequena fortuna, mas a perdeu durante a crise econômica de 1929. Zborowski morreu em Paris, em 1932. 
Figura 18: "Convite da exposição coletiva de Modigliani", 1919, Inglaterra, fotografia

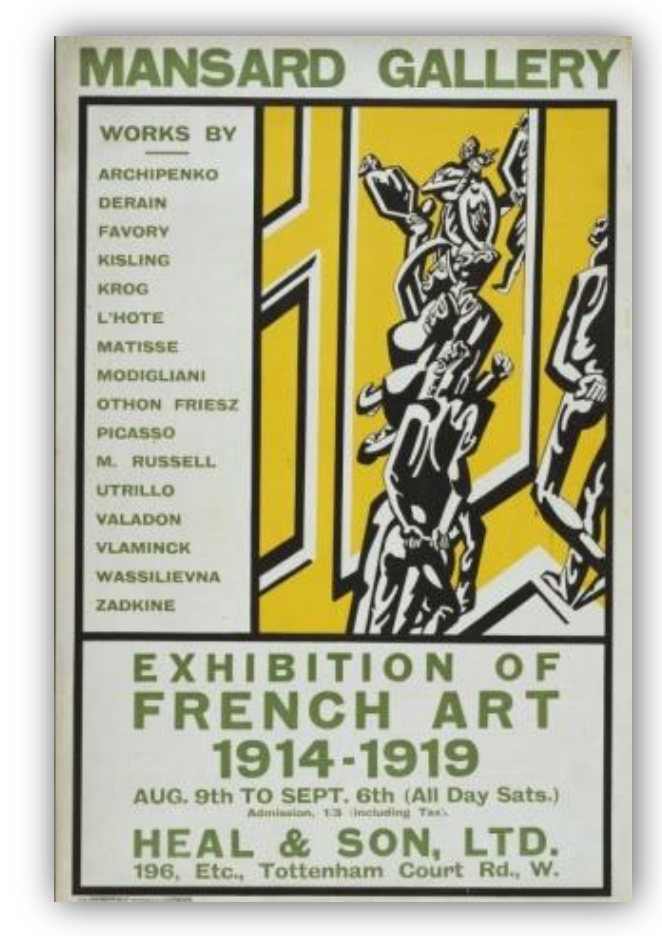

Fonte: PARISOT, 2006, p. 218.

Em maio, Modigliani retornou a Paris e assinou um documento se comprometendo a casar com Jeanne. Em julho, Jeanne descobriu que estava grávida novamente e continuou a ser expurgada por sua família, por viver com Modigliani.

\subsection{O Expirar}

No dia 22 de janeiro, o pintor Ortiz de Zarate foi visitar Modigliani em seu apartamento e o encontrou no colo de Jeanne, cuspindo sangue e saudando a Itália. Um médico foi chamado e decidiu transferi-lo para o hospital. A meningite tuberculosa havia vencido a guerra. Modigliani faleceu aos trinta e seis anos incompletos, no Hospital Charité de Paris, na Rue Jacob, no dia 24 de janeiro de 1920, às 20h45. No necrotério, Jeanne, companheira apaixonada, permaneceu um longo tempo só, próxima 
ao corpo de Modigliani. Cortou uma mecha de seu cabelo e a colocou sobre o corpo de Modigliani. Grávida de oito meses do segundo filho, 'sobreviveu' apenas uma noite. Às três da manhã do dia 25 de janeiro, transtornada se atirou do quinto andar da casa de seus pais. Ela tinha apenas 21 anos de idade.

Uma multidão silenciosa assistiu ao funeral de Modigliani no Cemitério PèreLachaise, onde se encontra sua lápide (Figura 19), perto do jazigo do grande escritor Apollinaire. Soutine chorava nos braços de $\mathrm{Kiki}^{58}$. Os amigos levaram flores. O féretro foi organizado pelos amigos e pago por Kisling, seu amigo e companheiro de ofício de Modigliani (NICOSIA, 2011).

Figura 19: "Pedra Mortuária", 1930, Cemitério Père-Lachaise, Paris, fotografia

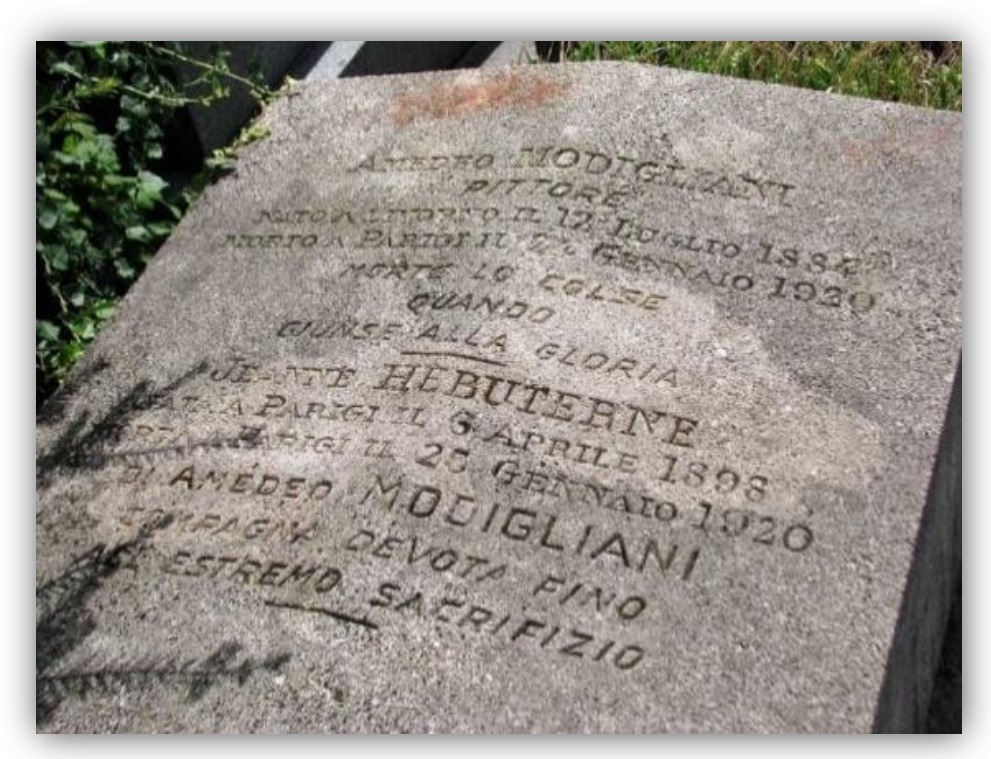

Fonte: GALLAND, 2005, p. 156.

O corpo de Jeanne foi velado e sepultado às escondidas pelos seus pais, no Cemitério de Bagneux. Apenas dez anos depois, Jeanne e seu filho, que não chegou a

\footnotetext{
58 Kiki de Montparnasse (1901-1953) foi uma modelo, musa e amante de artistas famosos. Ela foi também cantora e dançarina.
} 
nascer, foram transferidos para o Cemitério Père-Lachaise para descansarem ao lado de Modigliani.

Após o falecimento de Amedeo Modigliani, Emanuelle Modigliani, seu irmão político, buscou sua sobrinha Jeanne, em Paris, levando-a para o seio da família em Livorno, para ficar sob os cuidados de Margherita, sua tia, irmã de Modigliani sendo, então, adotada por ela e passando a residir em Florença. Posteriormente, em 1904, Jeanne escreveu uma importante biografia sobre seu pai intitulada: "Jeanne Modigliani Racconta Modigliani” (1984).

Dada a sua importância e à valorização de suas obras, Modigliani foi tema de dois filmes importantes. O primeiro intitulado "Os amantes de Montparnasse”, de 1958, biografia dirigida por Jacques Brunius e Max Ophüls que retratou os últimos anos de vida do artista (1919 e 1920). Modigliani é representado como um artista amargurado, que se embriaga por hábito, por vício, apaixonado por Jeanne, que apesar da incompatibilidade com sua família, compartilha a vida com o artista, enfrentando dificuldades diárias, pois Modigliani não se firmava e mergulhava na devassidão. É um filme que relata a visão do modo de vida dos artistas no principio do século $\mathrm{XX}$. $\mathrm{O}$ segundo filme é "Modigliani, a paixão pela vida", de 2004, dirigido por Mick Davis. Andy Garcia atua no papel de Modigliani, personificando o boêmio pintor, retratado com muita poesia em uma Paris de artistas. O filme mostra seus casos, suas obras e suas brigas com Picasso, de uma maneira bem "hollywoodiana", ou seja: uma vida de artista. Neste filme, Modigliani sobe nas mesas para declamar poemas com eloquência e, no momento em que pinta o retrato de Jeanne Hébuterne, Modigliani lhe diz: "Chame-me de Modi. Agora vou pintar você, e se eu tiver sorte, um dia pintarei seus olhos...”. 


\section{CAPÍTULO 2}

A TRADIÇÃO JUDAICO-CABALISTA 


\section{CAPÍTULO 2 - A TRADIÇÃO JUDAICO-CABALISTA}

\subsection{A Cabala: Conceito}

A palavra "Cabala", de origem hebraica ${ }^{59}$ (Figura 20), literalmente significa receber, mas pode também ser interpretada como Tradição ${ }^{60}$ ou método esotérico ${ }^{61}$ (UNTERMAN, 1992). A Cabala surgiu e se desenvolveu originalmente dentro do pensamento judaico. Os conceitos da Cabala formaram um ensinamento esotérico para explicar o mundo invisível, interpretando questões espirituais, aprofundando-se na ontologia (GUINSBURG, 1967). Segundo Scholem:

Cabala (hebr.: Kabalah) é o termo tradicional e mais comumente usado para designar os ensinamentos esotéricos do judaísmo e do misticismo judaico, especialmente nas formas adquiridas na Idade média, do século XII em diante. No sentido mais amplo, significa todos os sucessivos movimentos esotéricos do judaísmo que envolveu desde o período do Segundo Templo e se tornaram fatores ativos na história judaica (SCHOLEM, 1989, p. 03).

\footnotetext{
${ }^{59}$ Hebraico é o idioma relativo ao povo hebreu. É o idioma da família semítica falado pelos hebreus, no qual foi escrito quase todo o Velho Testamento (a Bíblia dos hebreus), e que, no século XIX, após transformações históricas, ressurgiu com o movimento sionista, tornando-se o idioma oficial do Estado de Israel.

${ }^{60}$ Tradição é o ato ou efeito de transmitir ou entregar, a transferência de comunicação oral de fatos, lendas, ritos, usos e costumes etc. de geração para geração, é uma herança cultural, legado de crenças, técnicas. Um conjunto dos valores morais, espirituais transmitidos de geração em geração (CHEV ALIER, GHEERBRANT, 1986).

61 Esotérico é um termo de atitude doutrinária, pedagógica ou sectária segundo a qual certos conhecimentos relacionados com a ciência, com a filosofia e com a religião não podem ou não devem ser vulgarizados, mas comunicados a um pequeno número de iniciados. Esta ciência, doutrina ou prática também é baseada em fenômenos sobrenaturais de derivação de sentido figurado com caráter de uma obra hermética e enigmática (PIKE, 1986).
} 
Figura 20: "Cabala no idioma hebraico", fotografia

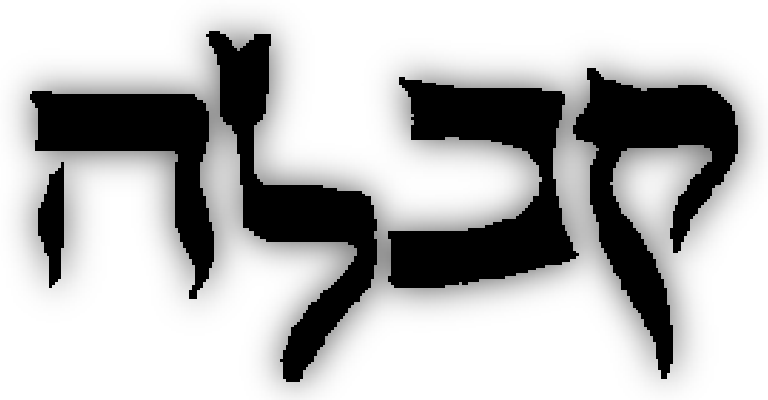

Fonte: DICIONÁRIO HEBRAICO-PORTUGUÊS, 1988, p. 210.

As definições de Cabala foram formuladas por membros da comunidade judaica, tanto religiosos como pensadores/filósofos. Para Leone:

A religião é a resposta humana daquele que se percebe na situação de estar diante do divino. Essa é, em síntese, a posição defendida por Abraham Joshua Heschel (1907-1972) sobre o significado do conceito religião. O corolário dessa afirmação é que a religião nasce a partir de uma experiência e é a resposta humana a essa experiência. Como resposta humana, ela está condicionada às situações histórico-culturais e ao contexto daquele que vivencia o encontro com Deus e, ao mesmo tempo, essa mesma experiência é produzida pelo divino que veio à procura humana (LEONE, 2011, p. 1).

\subsection{Tradição e História}

A Cabala é comumente usada para apresentar ensinamentos religiosos e esotéricos no judaísmo ${ }^{62}$. O judaísmo, por sua vez, é originado dos ensinamentos da Torá $^{63}$ que, para o povo judeu ${ }^{64}$, é uma composição constituída pelos cinco primeiros

\footnotetext{
${ }^{62}$ Judaísmo é o termo relativo ou pertencente aos judeus.

${ }^{63}$ Torá é a Lei Mosaica. É o livro que contém essa lei, isto é, as escrituras religiosas judaicas conhecidas como Pentateuco.

${ }^{64} \mathrm{O}$ termo Judeu refere-se ao povo da antiga tribo de Judá ou indivíduo dessa tribo. Relativo ao antigo reino hebreu de Judá (930-586 a. C.) (UNTERMAN, 1992).
} 
livros do Tanakh $^{65}$, chamados de Pentateuco ${ }^{66}$, para os cristãos ${ }^{67}$, e que também é apoiada pelo Talmud $^{68}$. Estes livros são a base para o judaísmo e é por este motivo que o povo judeu é conhecido como "O povo do Livro", que poderia ser 'dos livros' (GUINSBURG, 1967). Esses livros, como o da Figura 21, criaram a aliança desenvolvida entre o povo judeu e a divindade $D^{\prime} u s^{69}$ (BIALE, 2004).

Figura 21: "Torá", livro de rolo, fotografia

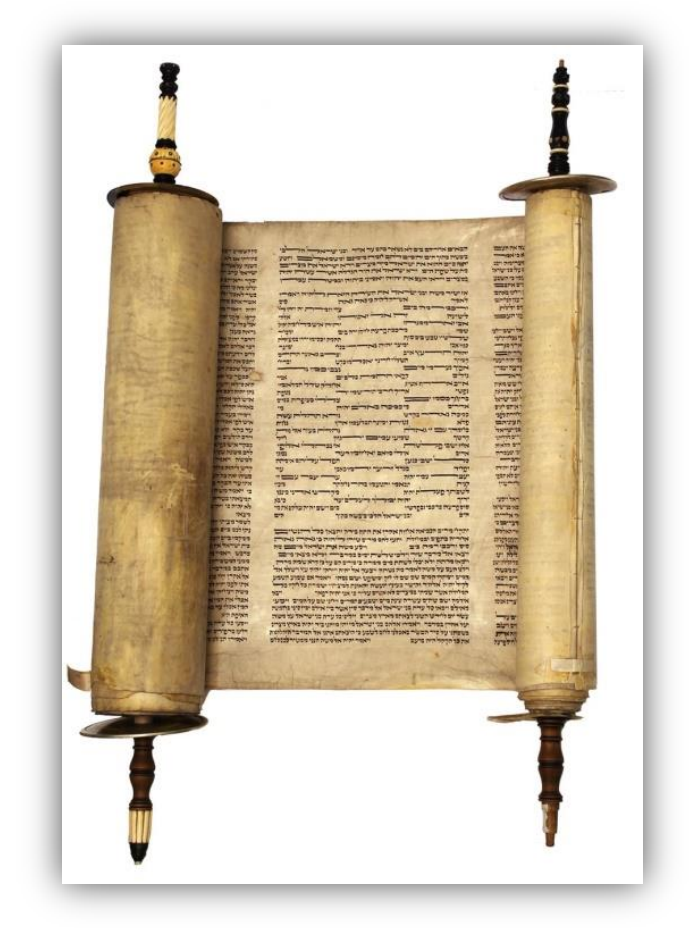

Fonte: UNTERMAN, 1992, p. 235.

\footnotetext{
${ }^{65}$ Tanakh ou Tanach (em hebraico ר"נת) é um acrônimo utilizado dentro do judaísmo para denominar seu conjunto principal de livros sagrados, sendo o mais próximo do que se pode chamar de uma Bíblia judaica (UNTERMAN, 1992).

${ }^{66}$ Pentateuco é a coleção dos cinco primeiros livros do Velho Testamento: Gênesis, Êxodo, Levítico, Números e Deuteronômio.

${ }^{67}$ Cristão diz-se de ou daquele que professa ou frequenta igreja de uma das modalidades do cristianismo. Cristianismo é a religião da fé em Jesus Cristo, judeu redentor.

${ }^{68} \mathrm{O}$ Talmud é uma série de livros da religião judaica que contém a lei oral escrita. Traz a doutrina, a moral e as tradições dos judeus. Surgiu da necessidade de complementar a Torá. Foi editado originalmente em aramaico, reunindo textos do século III até o século V (UNTERMAN, 1992).

${ }^{69} D^{\prime} u s$ (Deus) ente infinito, eterno, sobrenatural e existente por si só; causa necessária e fim último de tudo que existe.
} 
A Cabala surgiu e se desenvolveu dentro destes registros. Para compreender estes ensinamentos esotéricos criou-se toda uma metodologia mística ${ }^{70}$, a partir de um estado de contemplação dos pensadores da Idade Média, que por volta do século XII em diante, tornaram-se representativos. A Cabala não é um sistema único, linear; sua compreensão existe em várias abordagens. Sua linha simbólica tem como forma histórica os livros: Sefer ${ }^{71}$ ha-Bahir (Livro da Iluminação), Sefer Ietsirah (Livro da Criação) e Sefer Zohar (Livro do Esplendor), (BENSION, 2006).

O Sefer ha-Bahir (Livro da Iluminação) surgiu na passagem do século XII para o XIII, no sul da França; são desconhecidas as circunstâncias de seu surgimento (KAPLAN, 1989). Ele adota uma estrutura simbólica e é atribuído ao Rabi Nechunia ben Hakanah, tanaíta $^{72}$ do século I, segundo a tradição. Contém uma ordem aleatória, podendo ser uma coletânea de várias fontes. Este livro foi também atribuído a Isaac, o Cego (1160-1235), segundo indicação de Gershom Scholem (1897-1982), maior historiador sobre a Cabala no século XX. Sua maior importância habita no emprego da linguagem simbólica comum e nas implicações filosóficas aceitas pela tradição mística (HAKANÁ, 2013).

O Sefer Ietsirah (Livro da Criação) tem estilo obscuro. É o texto hebraico mais antigo que contém uma forma sistemática. Seu conteúdo é também o mais antigo do pensamento místico. São duas versões, uma mais curta e uma outra com apêndice. Ambas já existiam antes do século X, quando foram traduzidas para o árabe por Saadia Gaon (892-943). A tradição atribuiu a Abraão (1600 a. C.) e ao Rabi Akiva (50-135) a sua escrita. Sua linguística remete aos escritos do Merkaba ${ }^{73}$, o que leva a crer que esse

\footnotetext{
${ }^{70}$ Mística é a inclinação para acreditar em forças e entes sobrenaturais. Crença de que o ser humano pode comunicar-se com a divindade ou receber dela sinais ou mensagens, tendência para a vida contemplativa.

${ }^{71}$ Sefer significa livro em hebraico.

${ }^{72}$ Tanaíta, do hebraico נאים, é termo usado para designar os sábios rabínicos entre os anos de 30-200.

${ }^{73}$ Merkaba é uma tradição mística da cabala que retrata o Merkaba ou Trono ou Carro de D’us, que podia subir ou descer através de diferentes câmaras ou palácios celestiais.
} 
texto situa-se entre os séculos III e IV, na Palestina. Seu tema principal é a $\operatorname{cosmogonia}^{74}$, mas também aborda as 22 letras do alfabeto hebraico e as 10 Sefirot, somando ( soma teosófica $^{75}$ ), os 32 caminhos secretos da sabedoria mística. Trata-se do processo linguístico e gramatical do misticismo tradicional judaico.

Sefirot (sefira é unidade, sefitot é o plural) é uma palavra feminina do hebraico que significa vasos esféricos ou círculos compostos de 10, que formam a Árvore Cabalista. Eles representam 10 nomenclaturas dos princípios da criação. Estão dispostas em três triângulos estando a décima esfera isolada na parte inferior, criando, assim, a Árvore Sefirótica ou a Árvore Cabalista. As esferas, ou sefirot, estão ligadas entre si por linhas, canais, onde estão as 22 letras do alfabeto hebraico que indicam o caminho, tendo o somatório de 32 marcos de meditação, pontos de estudo, pontos de conhecimento, cheios de simbolismo arquétipo que nos é revelado com o estudo das mesmas, a grafia para $D^{\prime} u s(\mathrm{ROOB}, 2001)$.

O Sefer Zohar (Livro do Esplendor) é uma coletânea de várias seções, com pronunciamentos midráshicos ${ }^{76}$, dialéticas de vários tópicos e homilias. Supostamente escrito por Simeon bar Yochai, tanaíta do século II, mas também existem seções anônimas. É composto por cinco volumes, cada qual composto basicamente por 22 seções. A maior parte está escrita em aramaico $^{77}$ e uma pequena parte em hebraico. Porém, a escrita não detém o formato da linguagem do Talmud, pois o sistema da literatura não é deste período. Assim, eruditos a partir do século XIV, apontam como

\footnotetext{
${ }^{74}$ Cosmogonia é o corpo de doutrinas, princípios (religiosos, míticos ou científicos) que se ocupa em explicar a origem, o princípio do universo: cosmogênese.

${ }^{75}$ Teosófica ou teosofismo é conjunto de doutrinas religiosas de caráter sincrético e místico, acrescidas eventualmente de reflexões filosóficas, que buscam o conhecimento da divindade para alcançar a elevação espiritual (PIKE, 1986).

${ }^{76}$ Midráshicos é o termo hebraico Midrash (em hebraico: שרדמ; investigar ou estudo) é um método homilético (pregação ou formação textual) da exegese (interpretação crítica) bíblica. O termo também se refere à compilação integral dos ensinamentos homiléticos sobre a Bíblia (UNTERMAN, 1992).

${ }^{77}$ Aramaico é o idioma relativo ou pertencente aos arameus. Diz-se de ou língua semítica falada pelos arameus da antiga Síria e da Mesopotâmia, ainda hoje falada em alguns pontos dessas regiões, o neosiríaco.
} 
autor, Moisés de Leon (1250-1305), cabalista $^{78}$ espanhol. Seu período de execução gira em torno de 1280/90, entre a Espanha e a França (YEHUDA, 2013).

A união destes livros com a filosofia neoplatônica ${ }^{79}$ e a aristotélica $^{80}$, redescobertas neste período, levou à criação de um pensamento cabalístico que tem fundamental relação com o problema existencial do divino (HAUSER, 1995).

Do século XV em diante, cristãos místicos e teólogos ligaram a doutrina cabalista com o cristianismo. Suas duas fontes procedem de judeus convertidos e da Academia Platônica, subvencionada pela família Medici ${ }^{81}$ de Florença. Idel ressalta que “o interesse pela Cabala durante o período da Renascença foi compartilhado por judeus e cristãos italianos; ainda que servissem de ponte entre as duas religiões, ela era explorada para atividades missionárias cristãs" (IDEL, 2000, p. 372).

A Cabala, como sistema filosófico-religioso judaico medieval, integra elementos que compreendem preceitos práticos, especulações de natureza mística e afirma que o universo é uma emanação ${ }^{82}$ divina. Esta interpretação e o decifrar ocorrem de forma supostamente metodológica, apoiada e embasada no desenvolvimento do judaísmo; sua contribuição fortaleceu a comunidade judaica. Aproximadamente do século XVI ao XIX, foi considerada a verdadeira teologia judaica (IDEL, 2000).

\footnotetext{
${ }^{78}$ Cabalista é o termo relativo à cabala, sistema filosófico, exegese, ou o que é versado nela, que ou o que pratica ou conhece alguma ciência oculta, doutrina esotérica ou técnica mágica ou adivinhatória (UNTERMAN, 1992).

${ }^{79}$ Neoplatônica foi uma escola filosófica alexandrina surgida no século II e em expansão até o século V, que interpreta o platonismo de forma mística e espiritualista, supondo a transcendência de um deus que, por emanação, cria a realidade profana, e a possibilidade de que o ser humano, em um movimento de interiorização contemplativa e retorno às suas origens, restabeleça a união com a divindade. Seu principal representante é o filósofo egípcio Plotino (205-270).

${ }^{80}$ Aristotélica é a doutrina de Aristóteles (384-322 a. C.), filósofo grego de origem macedônica. É caracterizada pela diversidade e complexidade temática - sistematização e aperfeiçoamento de todos os saberes de seu tempo - com profunda influência sobre o desenvolvimento posterior da cultura ocidental (NICOLA, 1982).

${ }^{81}$ A família Medici foi uma família rica e poderosa de banqueiros e comerciantes. Tiveram seu apogeu nos séculos XV e XVI, quando dominaram Florença, na Itália, e acabaram por estender seu poder por toda a Toscana (NICOLA, 1982).

${ }^{82}$ Emanação, segundo o pensamento de Plotino (205-270) ou Schelling (1775-1854), é o processo no qual a divindade suprema irradia, emite ou propaga sua própria substância, criando o universo, uma extensão de sua natureza divina, de maneira processual, contínua e permanente (NICOLA, 1982).
} 


\subsection{A Mística Judaica}

Como hermenêutica ${ }^{83}$, a Cabala desenvolveu a Gematria ${ }^{84}$, como podemos observar na Figura 22, conhecida como "numerologia judaica". Trata-se de um método de análise das palavras bíblicas que atribui um valor numérico definido a cada letra da Torá.

Figura 22: "Tábua do alfabeto judaico", fotografia

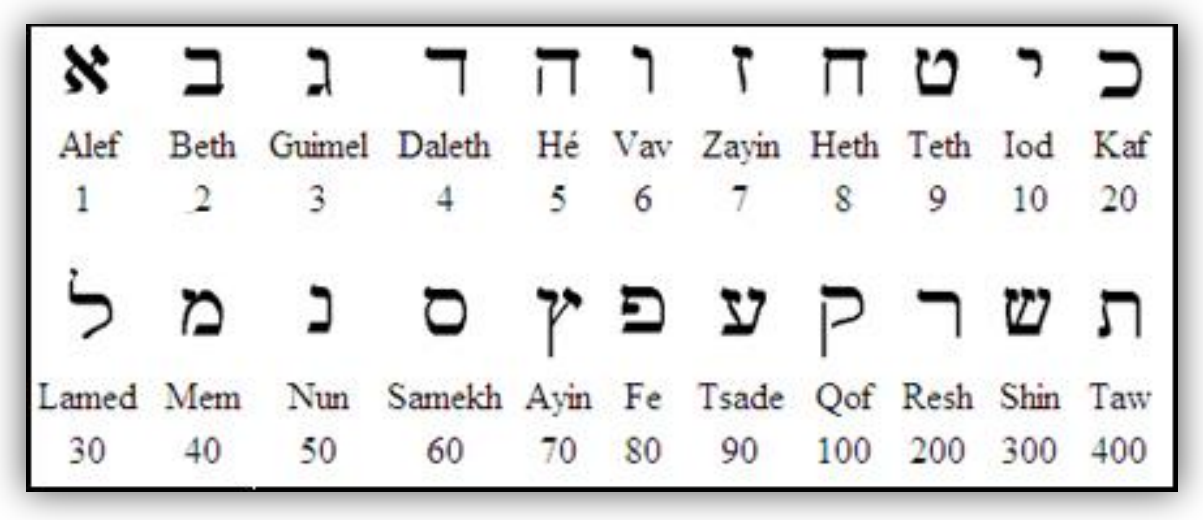

Fonte: KAPLAN. 2002, p. 50.

Esta hermenêutica também é utiliza da chamada Árvore Cabalista, uma estrutura organizacional, um organograma de sistema hierárquico com a forma de árvore, que é dividida em dez partes conhecidas por sefirot, que recebem também o nome de Árvore Sefirótica, pois a árvore representa o mundo superior e o mundo inferior na mística religiosa. Esse método trata da emanação da criação do Universo, da criação do Mundo, e da hierarquia do processo evolutivo do homem (estados de consciência).

\footnotetext{
${ }^{83}$ Hermenêutica é a ciência que tem por objeto a interpretação de textos religiosos ou filosóficos, especialmente das Sagradas Escrituras. Nas interpretações dos textos e no sentido das palavras utiliza-se a base semiótica, teoria esta da ciência voltada à interpretação dos signos e de seus valores simbólicos (ZANIAH, 1982).

${ }^{84}$ Gematria é a regra hermenêutica que consiste em explicar uma palavra ou um conjunto de palavras, conferindo um valor numérico convencionado a cada letra. São criptogramas sob a forma de uma palavra cujas letras têm valores numéricos, tomada com sua significação oculta (ZANIAH, 1982).
} 
A Árvore Cabalista ou Sefirótica tem início no mundo superior na sefira número um. Seus números e nomes em hebraico e a tradução de cada sefira são: 1 Kether, Coroa; passando por 2 Chochmah, Sabedoria; 3 Binah, Compreensão; 4 Chesed, Graça; 5 Guewuráh, Força; 6 Tiphereth, Beleza; 7 Netzah, Vitória; 8 Hod, Honra; 9 Jesod, Fundação; chegando ao mundo inferior 10 Malchuth, Mundo (Figura 23) (SCHOLEM, 1989).

Figura 23: "Árvore Cabalista”, 1516, gravura

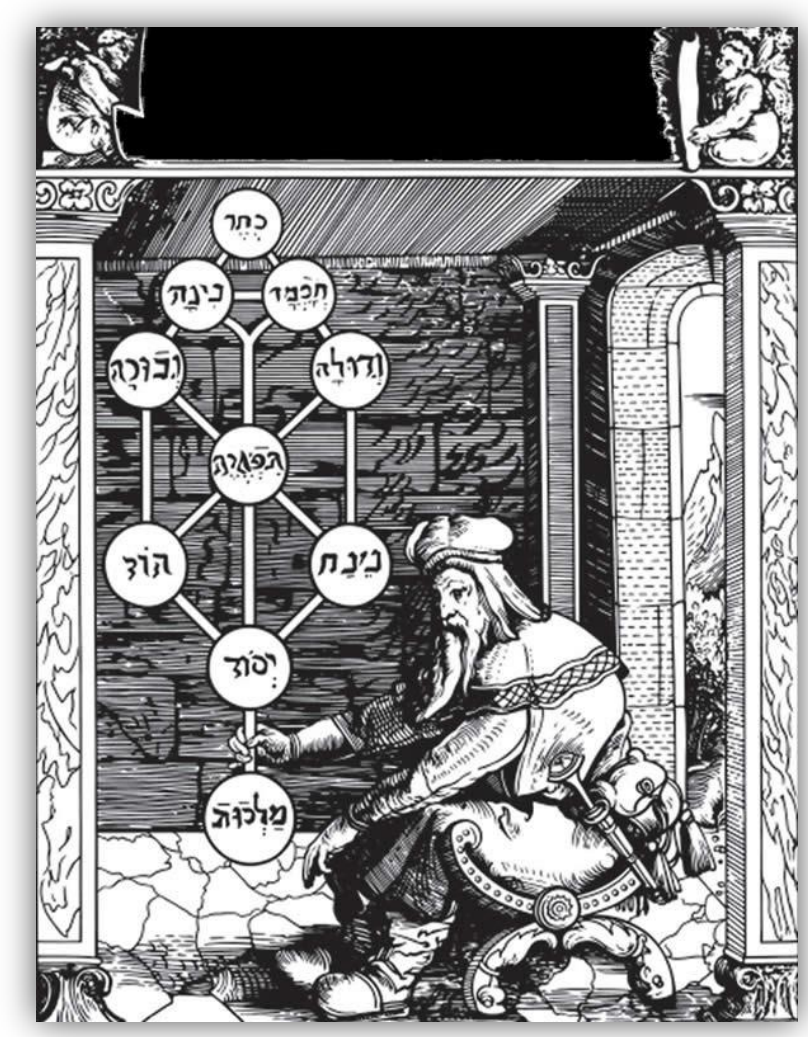

Fonte: SCHOLEM, 1989, p. 02.

As sefirot podem ser vistas como frutos, ligações, canais ou linhas que fazem a comunicação. São os galhos que contêm as 22 letras do alfabeto hebraico que indicam o caminho. Estas 10 sefirot, contendo as dez palavras, mais as 22 letras do alfabeto 
hebraico totalizam os 32 marcos de meditação. São letras-palavras símbolos, que criam as canalizadoras potências ${ }^{85}$, letras e palavras que desenvolvem as orações, estados de conhecimento cheios de simbolismo arquétipo que nos revelam o mapa para $D^{\prime} u s$ (ROOB, 2001).

O desenho da árvore com linhas ramificantes já existe desde as culturas da préescrita. Na Idade Média (476-1453), a Catedral de Chartres, construída entre 11931220, na França, já apresentava um vitral com estas ligações, uniões que representam a Árvore de Jessé $e^{86}$ (Figura 24).

Figura 24: “A Árvore de Jessé”, 1145, vitral, Catedral de Chartres

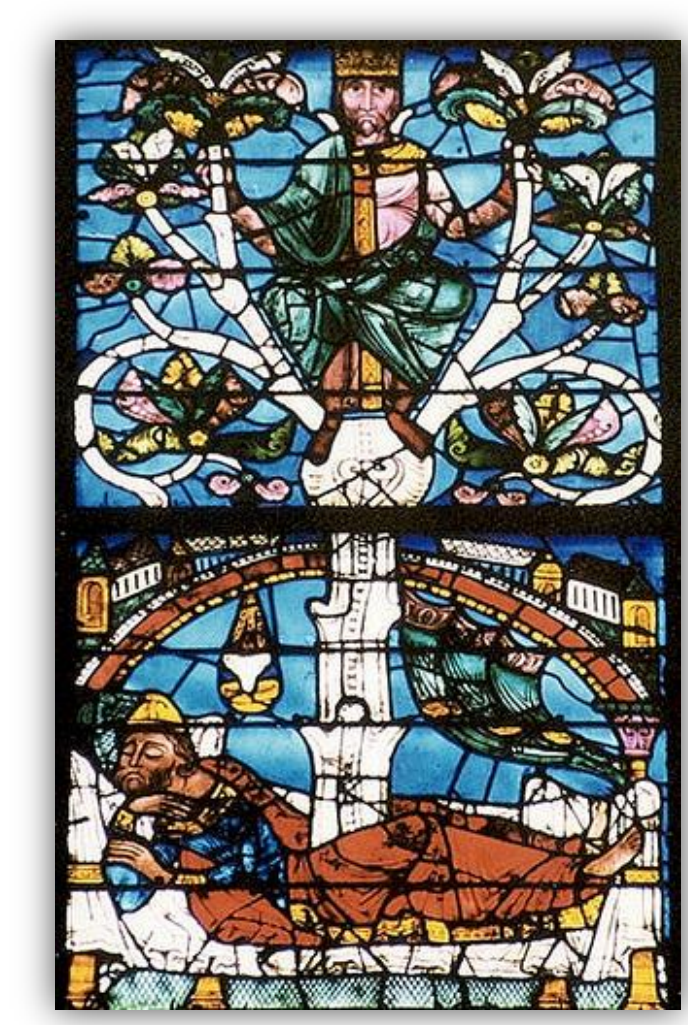

Fonte: OLDENBOURG, 1972, p. 206.

\footnotetext{
${ }^{85}$ Potências é um termo cabalístico de capacidade para criar, produzir, agir através da faculdade e possibilidade ou tendência de qualquer realidade material no sentido de se modificar ou de ser modificada, de tal forma que possa perfazer todas as determinações que ainda se mantêm apenas virtuais. ${ }^{86}$ Jessé (X a. C.) em hebraico Yíšay, quer dizer 'presente de $D^{\prime}$ 'us'. No Antigo Testamento da Bíblia e nos Livros de Samuel, é o pai do rei David de Israel, seu sétimo filho.
} 
A Árvore Cabalista, com círculos sefiróticos, pode ter surgido com a criação do telescópio, utilizado para observar o céu noturno, e apresenta a constância do círculo: as estrelas, os planetas e as rotas. No Renascimento (XIV-XVII), os cientistas, os filósofos, os médicos, os religiosos e os artistas eram entusiastas de todos os conhecimentos, de todas as disciplinas, buscando a unificação destes saberes: o homem renascentista.

As ramificações, ou seja, as canalizações utilizadas na Árvore Cabalista, que ligam os círculos, têm este formato. O círculo já era utilizado desde a Antiguidade como símbolo $^{87}$ místico e matemático, pois seu desenho não tem começo e nem fim; os filósofos $^{88}$ (termo utilizado no Renascimento para os que buscam a sabedoria), o qualificaram com um signo ${ }^{89}$, símbolo da divindade, pois, no céu existem as estrelas e os planetas que são circulares, assim com suas trajetórias que também são circulares.

Criando círculos na tridimensionalidade, estes se tornam vasos, que se tornam receptáculos de líquidos, assim como a luz que é descida, derramada sobre a Terra pelos raios do Sol (estrela), adquirindo um aspecto místico de divindade.

A Cabala, ao unir este aspecto com a classificação numeral, com a nominal e com questões religiosas, equiparou todas estas disciplinas chegando a uma explicação da divindade, criando um método, um mapa, para o autoconhecimento e para chegar a D’us. O Sol é o símbolo máximo da existência. Ele nos fornece a vida e a luz. Sua ligação simbólica com o ouro ${ }^{90}$ é óbvia: a cor; desencadeando-se na simbologia da

\footnotetext{
${ }^{87}$ Símbolo é aquilo que, por convenção ou por princípio de analogia formal ou de outra natureza, substitui ou sugere algo: Ex.: o caduceu é o símbolo da medicina; emblema, insígnia; pessoa ou personagem que se torna representativa de determinado comportamento ou atividade. É uma palavra ou imagem que designa outro objeto ou qualidade por ter com estes uma relação de semelhança (HOUAISS, 2009).

${ }^{88}$ Filósofo é uma palavra do grego que significa 'quem ama a sabedoria'. É um ser movido pela consciência lúcida da ignorância inerente à condição humana, criada por Pitágoras (século VI a.C.).

${ }^{89}$ Signo é um sinal indicativo em semiologia de qualquer objeto, forma ou fenômeno que representa algo diferente de si mesmo e que é usado no lugar deste numa série de situações.

${ }^{90}$ Ouro do latim aurum = aura. Símbolo Au. Metal utilizado como lastro do papel-moeda. Dourado, cor do sol.
} 
aura $^{91}$, como símbolo de luz derramado metaforicamente como líquido sobre nosso planeta, através dos raios solares, lavando o planeta com sua luz, como podemos observar na Figura 25. Nessa imagem, uma família egípcia, criadora do monoteísmo, está simbolicamente sendo banhada pelos raios solares, como o signo falo ${ }^{92}$ e a Terra, Gaia $^{93}$, signos da grande mãe, fecundada pelos poderes da luz divina que está no espaço, no céu, nas alturas, no altar na religião cristã, onde se localiza o filho de Deus.

Figura 25: "Oferenda ao Sol, Akenáton e Nefertiti", 1336 a. C. XVIII dinastia, argila

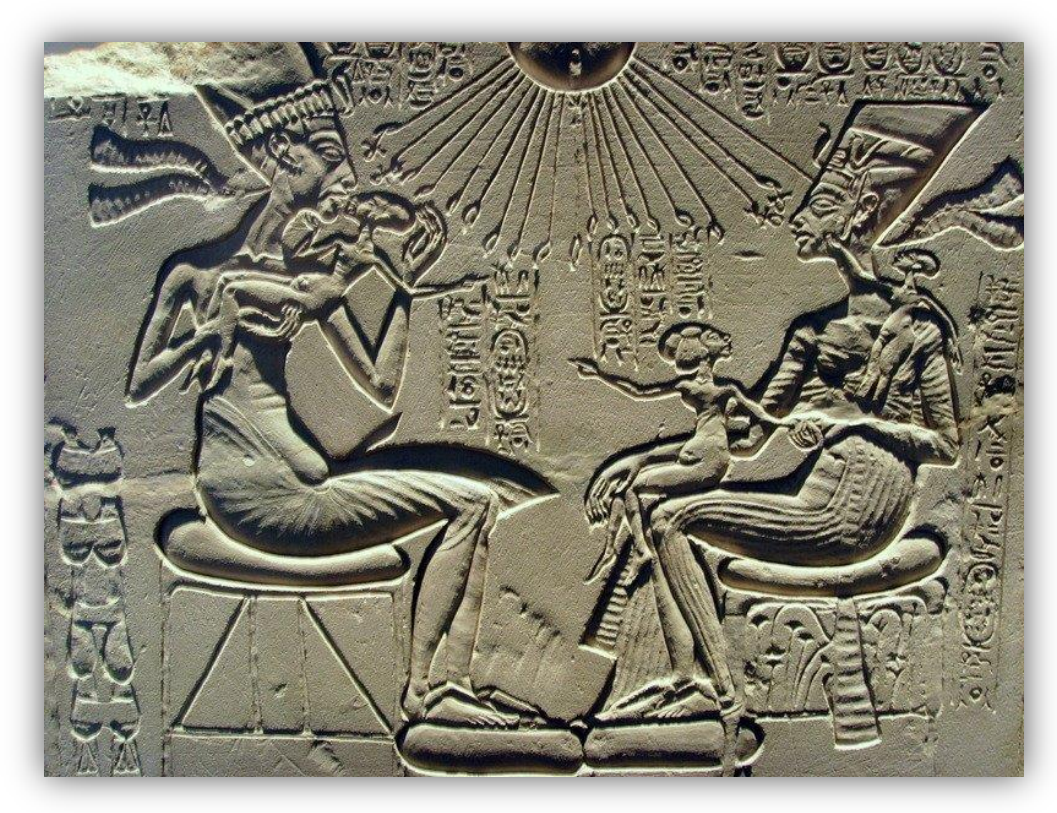

Fonte: MICHALOWSKI, 1986, p. 397.

\footnotetext{
${ }^{91}$ Auras são irradiações entorno do Sol; também um suposto campo de energia que irradia dos seres vivos.

${ }^{92}$ Falo é a imagética do órgão reprodutor masculino, carregada nos antigos festivais em honra a Dioniso e Baco, para simbolizar o poder gerador da natureza.

${ }^{93}$ Gaia na mitologia grega é a Mãe-Terra, como elemento primordial e latente de uma potencialidade geradora.
} 
Uma das disciplinas mais valorizadas na Renascença era a Alquimia ${ }^{94}$, que deu origem à várias outras disciplinas como a Química, a Farmácia, a Homeopatia, a Psicologia entre outras. Os laboratórios utilizados por estas especialidades incluíam a destilação, como observamos na Figura 26, com vasos para decantar e separar líquidos. Decantar é um verbete também utilizado como vatinação (adivinhar, do latim), ou seja, decantar era cantar a oração do ato de profetizar, pois, no próprio ambiente de trabalho, o alquimista divinizava a deus. O laboratório era também um local de oração, ambiente de referência a Deus: o Vaticano (ELIADE, 1992).

Figura 26: "Desenho de Tribikos" 95,

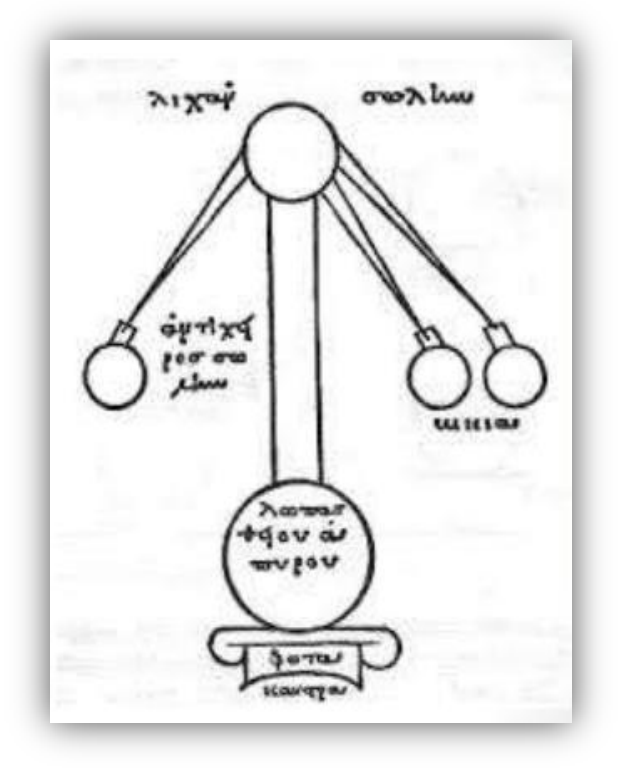

Fonte: PATAI, 2009, p. 121.

\footnotetext{
${ }^{94}$ Alquimia é uma palavra árabe que dá origem à palavra química. Porém, a química na Idade Média, procurava descobrir a panaceia universal, o remédio contra todos os males físicos e morais conhecido como a pedra filosofal e que deveria transformar os metais não nobres em ouro.

${ }^{95}$ Tribikos é uma espécie de alambique com três braços utilizado para obter as substâncias purificadas por destilação e sublimação. Maria, a Judia (273 a. C., Egito), foi sua inventora, e também do banho-Maria, credita Zósimo (300 a. D. Grécia) alquimista e gnóstico.
} 
A Cabala é o somatório da combinação dos pensamentos: a meditação contemplativa e o pensamento racional. Suas grandes heranças tradicionais, como mencionamos anteriormente, foram a Bíblia/Torá e o judaísmo talmúdico e, paralelamente, também a filosofia grega, que abarcava o neoplatonismo e o aristotelismo existentes na Idade Média. A integração destes textos com os livros Sefer Bahir, Sefer Ietizira e o Sefer Zohar desenvolveram um conteúdo sistemático para o conhecimento do misterioso mundo teológico com várias formas de interpretação do chamando mundo divino, relativo à proveniência de $D^{\prime} u s$, considerando-se a existência de um mundo sobrenatural, sublime, o mundo sagrado.

(...) Era o nome Hachamim entre os Hebreos o próprio, que Sophi entre os Gregos, \& com ele denotava todo o fogeyro fapiente. Mas depois, que tanto começáraô a florecer entre eles, aquelles verdadeyros Sabios, $\mathrm{q}^{\prime}$ da boca do Senhor ouviraô a certíssima doutrina, deraõ a estes taes os nomes de Profetas, que isso quer dizer Nabi, do verbo Naba, idea, certa prediçaõ do futuro; porque o nome Profeta, de voz Grega, he quase vaticinante... ${ }^{96}$ (MELLO, 1724, p. 15).

O envolvimento da Cabala com as vanguardas da arte fica evidente no grupo de artistas chamados Les Nabis, ou Nabis, palavra hebraica que significa profetas. O título foi criado pelo médico francês e também poeta simbolista Henri Cazalis (1840-1909), indicando que os novos artistas seriam os profetas da arte. Este grupo de jovens artistas pós-impressionistas foi impulsionado por Paul Sérusier (1864-1927) e liderado por Paul Gauguin (1848-1903), antecedendo aos fauvistas. Suas influências pertencem aos simbolistas. Os mais conhecidos do grupo foram Pierre Bonnard (1867-1947) e Edouard Vuillard (1868-1940). O produto da expressão destes artistas habitou na realização de

\footnotetext{
${ }^{96}$ Transcrição em língua portuguesa atual: Era o nome Hachamim entre os Hebreus o próprio, que Sophi entre os Gregos, e com ele denotava todo o fogeyro fapiente. Mas, depois que tanto começarão a florescer entre eles, aqueles verdadeiros Sábios, que da boca do Senhor ouvirão a certíssima doutrina, dirão a estes tais os nomes de Profetas, que isso quer dizer Nabi, do verbo Naba, ideia, certa predição do futuro; porque o nome Profeta, de voz Grega, é quase vaticinante...
} 
suas obras em puro sentimento visual; abriram o caminho para obras abstratas, que culminariam no centro de criação de artistas judeus; provavelmente pela não utilização de imagens nas sinagogas. Estes artistas e este movimento antecederam à ida de Modigliani a França mas, até mesmo pelo título do grupo, fica evidente que influências judaicas eram fortes neste período, principalmente em Paris, uma vez que o estudo sobre magia, ocultismo, esoterismo e a Cabala estavam em evidência.

Paris vivia um momento de explosão de conhecimento, encantamento com as novas tecnologias. Em sua vida noturna destacavam-se os cabarés, a moda, a música e, é claro, as artes plásticas. A cidade teve o epiteto de "Cidade Luz", originado por ter sido a primeira cidade iluminada por luz elétrica. Mas, este título abrangia a tudo, incluindo seu conhecimento "iluminante". Cabe lembrar, inclusive, que na França, no século XVIII, surgiu o Iluminismo ${ }^{97}$.

As ligações da Cabala com as Ciências e com as Artes ficam mais evidentes quando recordamos a atuação de Papus - apelido de Gérard Encausse (1865-1916), médico, escritor, ocultista ${ }^{98}$, rosacrucianista ${ }^{99}$, maçom $^{100}$, cabalista e um dos criadores da L'Ordre Kabbalistique de la Rose-Croix (Ordem Cabalista da Rosa+Cruz), como também de outro médico, Henri Cazalis, criador do termo Nabis.

A maioria dos verbetes utilizados nas artes plásticas é de origem alquímica: magnum opus, grande obra; matéria prima, criação original; artista, o artesão no laboratório; tintura, pintar etc.

\footnotetext{
${ }^{97}$ O Iluminismo foi um movimento intelectual do século XVIII, caracterizado pela centralidade da ciência e da racionalidade crítica no questionamento filosófico, Filosofia das Luzes.

${ }^{98}$ Ocultista é o crente na ação ou influência dos poderes sobrenaturais ou supranormais. O estudo desses fenômenos dá-se no conjunto das artes ou ciências ocultas, como a magia, o espiritismo, a astrologia etc.

${ }_{99}$ Rosacrucianista membro da Rosa+Cruz é uma confraria de iluminados existente na Alemanha desde o século XVI e difundida pelos países vizinhos no século XVII. Usa o emblema da rosa sobreposta à cruz e segue certas doutrinas espirituais e esotéricas.

${ }^{100}$ Maçom é o membro da maçonaria, uma confraria hermética, legalmente surgida em 1717 que tem como finalidade a prática da fraternidade e da filantropia. Usa emblemas, distintivos e um código de sinais secretos para se reconhecerem. Seus símbolos são o esquadro e o compasso.
} 
Modigliani nunca foi um simples artista, principalmente pela sua ancestralidade filosófica. Seu tradição remontou a Baruch Spinoza e atingiu seu pensamento e seu modo de ver o mundo. Recordamos que, no ano de 1656, a sinagoga portuguesa de Amsterdam puniu Spinoza com o chérem $^{101}$, ou seja, ele foi excomungado por seus postulados a respeito de $D^{\prime} u s$ em sua obra, na qual defendia que $D^{\prime} u s$ é o mecanismo imanente da natureza.

É tradição na cultura sefardita passar os conhecimentos de uma geração à outra, e o avô de Modigliani realmente o fez, ainda mais, ligando a cultura religiosa mística sefardita com o conhecimento da língua francesa, da italiana, da arte europeia e da filosofia mística de Spinoza.

Com esta experiência, Modigliani teve seu judaísmo enraizado, mesmo sendo um homem cosmopolita, um buscador da plenitude da vida que não via necessidade de frequentar a sinagoga, como seu antecedente que sofrera o chérem.

O debruçar de Modigliani sobre o filósofo Nietzsche fez com que ele pensasse na dicotomia apolíneo-dionisíaca sobre o übermensch (além-homem, ou super-homem); suas afirmações da vida, seus questionamentos sobre valores e objetividade da verdade se encontram no existencialismo ${ }^{102}$, como superação individual e transcendência do além da estrutura do contexto. Assim, ir além do humanismo.

O entorpecimento era desprezado na reprodução do mundo, com ojeriza pela subjetividade exagerada. Modigliani absorveu isso de Baudelaire, que queria realizar uma criação mágica sugestiva, que contivesse a um só tempo o objeto do sujeito, no qual o mundo exterior do artista é o próprio artista, ou profeta que, com os sentidos,

\footnotetext{
${ }^{101}$ Chérem é o mais alto grau de punição dentro do judaísmo, quando a pessoa é totalmente excluída da comunidade judaica.

${ }^{102} \mathrm{O}$ Existencialismo é o conjunto de teorias formuladas no século XX, com forte influência do pensamento de Kierkegaard (1813-1855), que se caracteriza pela inclusão da realidade concreta do indivíduo (sua mundanidade, angústia, morte etc.) no centro da especulação filosófica, em polêmica com doutrinas racionalistas que dissolvem a subjetividade individual em sistemas conceituais abstratos e universalistas.
} 
apreende a realidade concreta. Faz da arte poesia; a poesia que é arte; a arte que é mundo.

Modigliani assimilou vários conhecimentos durante sua vida, mas a escolha de ser artista deu-lhe a liberdade de viver. Ele recebeu os ensinamentos, por tradição, e a Cabala, também por escolha. Este conhecimento/instrumento permitiu que sua profissão de artista pudesse perceber e receber a qualidade mística em suas formas, de claro conteúdo sensível a sua jornada.

Suas transmissões irradiam um conjunto de saberes, coletado da tradição secular da análise de vida de um povo. Nas obras de Modigliani, vingam em suas formas, cores e perspectivas, o ato de se aperceber evidente, especialmente, em seus três autorretratos, como observaremos a seguir. Neles, é nítida a expressiva liberdade de um judeu capaz de expressar em seus estados alterados a emoção da complexa existência humana, que só poderiam ser representadas, por um artista de sensibilidade imbuída na tradição mística judaica, na Cabala.

Próximo capítulo, apresentaremos a obra de Modigliani a partir de um olhar atento à presença desses elementos da tradição judaica e de suas ligações com o mundo contemporâneo, buscando demonstrar como suas criações constituíram uma obra original, mas vinculada ao pensamento tradicional judaico-cabalista, comprovando então nossa tese. 


\section{CAPÍTULO 3}

A MÍSTICA JUDAICA NA OBRA DE MODIGLIANI 


\title{
CAPÍTULO 3 - A MÍSTICA JUDAICA NA OBRA DE MODIGLIANI
}

\begin{abstract}
Os caracteres hebraicos aparecem, como é sabido, com frequência na obra de Chagall, mas também comparecem na obra de Modigliani um pintor judeu que não explorou temática explicitamente judaica, embora seja interessante lembrar que o primeiro quadro que ele expôs em Paris, no Salon des Indépendents, em 1908, tivesse sido um portais intitulado A Judia. No retrato de 1916 da escultora Chana Orloff nascida na Ucrânia em 1888 e que, como Modigliani, participava do Círculo de Montparnasse, integrado por muitos artistas plásticos judeus que se estabeleceram em Paris vindos da Europa Oriental está escrito, em hebraico: "Chana, filha de Rafael" (CARNEIRO; LAFER, 2004, p. 18).
\end{abstract}

\subsection{Ligações para além da Arte}

Modigliani foi um artista. Sua capacidade de gestação do objeto habitava na elaboração, portanto, na construção, de forma ${ }^{103}$ e pensamentos ${ }^{104}$ que lhe preparavam para a realização. Esta feitura pede conhecimentos ${ }^{105}$ de seu próprio ser, de seu conteúdo genético $^{106}$, hereditário. Essa estrutura na obra de arte existe em conceitos que o sistema social delimita, ou seja, existem códigos, como os que Modigliani apresentava, que podem ser observados, por exemplo, na Figura 27, onde faz referência, em francês, entre outros assuntos à Tábua de Esmeralda (“La Table d'Emeraude"), um

\footnotetext{
${ }^{103}$ Forma é a configuração física característica dos seres e das coisas, como decorrência da estruturação das suas partes. Feitio, no aristotelismo, é o princípio que determina, modela ou delineia a matéria bruta, fazendo com que cada ser adquira uma identidade imagética, um traçado definido, uma configuração característica. No kantismo, cada uma das leis e estruturas inerentes ao espírito humano que possibilitam o ordenamento apriorístico do material múltiplo e caótico oferecido pelas sensações, viabilizando dessa maneira a compreensão da realidade (PIPER, 1984).

${ }^{104}$ Pensamentos são os estados do processo de raciocínio lógico, que exercem a capacidade de julgamento, dedução ou concepção (DORIN, 1978).

${ }_{105}$ Conhecimentos são atos do pensamento que permitem a apreensão de um objeto, por meio de mecanismos cognitivos diversos e combináveis, como a intuição, a contemplação, a classificação, a analogia e a experimentação.

${ }^{106}$ Genética é a ciência voltada para o estudo da hereditariedade, bem como da estrutura e das funções dos genes. É a teoria segundo a qual a percepção do espaço, do mundo exterior, através dos sentidos, não é natural, e sim adquirida pela experiência.
} 
texto ocultista escrito pelo lendário Hermes Trismegisto ${ }^{107}$, que trata de segredos hermenêuticos, que buscam alquimia na vida interior e na vida em sociedade; Modigliani também, no lado esquerdo do observador desenvolveu um poema tratando do copo (taça) como receptáculo da paixão e, ainda, diz que a virtude não está na vida extravagante ("la vertue c'est pas la le style flamboyant"). Desenhou, também, duas estrelas judaicas: um triângulo apontando para baixo e outro apontando para cima indicando a busca do equilíbrio. A recepção da estética habita na relação artista-obraobservador, através do confronto intelectual/anímico. O artista é seu corpo e seu meio. Sua sociedade, seus sócios, são seus espectadores e essa recepção cria a problematização do reconhecer.

Figura 27: Modigliani - Esboço "Símbolos Judaicos", 1915, 1sp, 54,5 x 43 cm, coleção particular

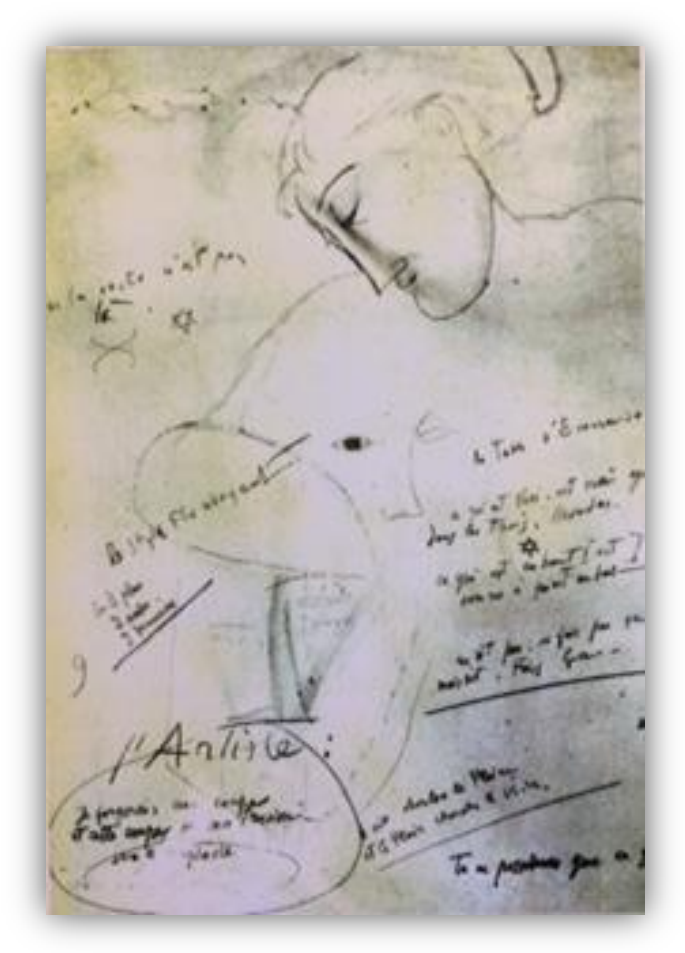

Fonte: GALLAND, 2005, p. 21.

\footnotetext{
${ }^{107}$ Hermes Trismegisto era um pensador egípcio, que viveu na região de Ninus por volta de 1.330 a.C., se deteve sobre filosofia, medicina e etc. $\mathrm{O}$ estudo sobre sua filosofia é denominado hermetismo que deu base para a Alquimia.
} 
Modigliani foi um filósofo, no conteúdo; um poeta, na forma; um desenhista, um escultor e um pintor com estilo próprio. Foi um apaixonado pelo fazer na arte. Sua base tradicional judaica sefardita, seu conhecimento de história da arte adquirido na Itália, sua técnica aprimorada na França, fizeram dele um grande artista. A boêmia de sua época foi totalmente vivenciada por ele, a ponto de suas façanhas se tornarem lendas; estórias sobre estórias que viraram história. Modigliani foi um homem bonito, sua finesse não o deixava arrogante. Dependendo de quem o observasse talvez o considerasse um conquistador e pedante. Chamavam-no de "príncipe" e, ao mesmo tempo, de "maudit" (maldito).

Realizador de sonhos, Amedeo foi um aventureiro da criação; um artista em sua mais profunda realidade. Buscou e encontrou no seu caminho a realização artística. Absorveu as proporções do belo, posteriormente criando seu próprio conceito de beleza, pois, em meio ao álcool, drogas e mulheres, ingeria Dante, Ducasse, Mallarmé, Nietzsche, Bergson, Spinoza e flutuava nas Artes plásticas.

Seu carisma advinha de seus filtros, filtros que alinhavam seus pensamentos com sua alma. As formas alongadas, em suas obras tinham conteúdo de ligação com outros mundos. Mesmo vivendo em um estado cosmopolita, típico de um homem de seu tempo, ainda assim vivia em mundos distantes e em seu próprio tempo. No Café Rosalie ou no La Rotonde era um ser próprio. Seu estado perdido não o deixava sem criação. Sua obscenidade era pura; seus nus eram mulheres desveladas, iniciadas. Seus retratos eram evidências de uma vida e continham significados judaicos velados; as formas eram condutoras; as cores eram seus conteúdos; os olhos eram reveladores. A transcendência mística era evidente, mesmo para o observador leigo.

Seu estilizar compunha com dor, experiências e vivências humanas. A distorção era sua forma de apresentação da realidade; sua assimetria mostrava a composição do 
vivido; seu desfocar, o contraste da vida, o aprisionamento da alma; a luz buscava equilíbrio, o estado assimilado de dor. Sua arte revela, desde as cariátides - com mulheres sofredoras - até seus nus - com mulheres esplendorosas na plenitude do viver suas noivas, suas esposas, suas companheiras, fossem mulheres de vida fácil ou nem tanto..

Os amigos de Modigliani eram marchands como Dr. Paul Alexandre, que o adotou; Zborovsky, que sempre lhe deu de tudo; Zarate, pintor chileno; Lipchitz, escultor que realizou sua máscara mortuária; Soutine, amigo da noite e do dia; Max Jacob, renegado judeu, seu querido; Jean Cocteau, poeta; Anna Akhmatova, Beatrice Hastings, Simone Thiroux, Elvira e outras, poetas, escritoras, suas amantes; chegando a Jeanne Hébuterne, seu grande amor e mãe de sua filha.

Modigliani, na busca pela compreensão da existência, buscou no filósofo e diplomata de origem judaica Henri Bergson (1859-1941) o apoio para seu entendimento sobre o mundo. Bergson utilizou em sua investigação filosófica o termo elã vital para designar um impulso original de criação do qual provém a existência. Modigliani identificava-se com este filósofo contemporâneo, especialmente no quesito oriundo da descoberta da alma, no estado de consciência tão evidenciado pelos meios da crítica da arte em relação à pintura dos olhos das pessoas retratadas, pois “os olhos, são as janelas da alma", como já havia afirmado Leonardo da Vinci (apud SUH, 2014), e abarcam um estado de luz enquanto conhecimento de um estado de consciência de plenitude perante o ser vivente.

Modigliani não só se identificou, mas dialogou com o bergsonismo, que se equaliza com os conhecimentos da Cabala na inteligência restrita à compreensão 
estática e mecanicista; a intuição ${ }^{108}$, incessante e levando a uma mobilidade criativa. Assim, Modigliani, em sua tradição cabalista, ligou-se a Bergson.

Modigliani é um ser humano que carregou consigo o Mundo. Suas obras expuseram os ideais da escola expressionista; sua manifestação artística trouxe sentimentos e emoções que podem ser somadas ao expressionismo. A realidade de suas obras não foi mundana; suas mulheres apresentam solidão simplesmente por estarem a sós na obra, mas suas características físicas são diversas; seus corpos estão nus, porém cobertos com cores quentes que transmitem o calor da sensualidade. Inúmeros estudiosos da arte, contudo, não o enquadram neste movimento artístico.

O estilo expressionista compreende a deformação do olhar. A realidade no expressionismo foi expressa na chamada forma subjetiva, pois se demonstram sentimentos simples na apresentação da realidade. Esta forma pode ser encontrada em vários momentos da História da Arte, como ocorre nas obras dos artistas Matthias Grünewald (1470-1528), Pieter Brueghel, o Velho (1525-1569), El Greco (1541-1614), Francisco de Goya (1746-1828) e até mesmo em Jackson Pollock (1912-1956) que trabalhava com o Expressionismo abstrato, com uma paleta cromática vincada e agressiva e recursos temáticos de solidão, que refletem a profundidade artística e demandam por intelectualidade. Modigliani também utilizou recursos expressionistas, mas foi muito além, pois foi também testemunha de seu tempo.

A Primeira Guerra Mundial (1914-1918) suscitou um desejo de transformação, alargando a imaginação e renovando a linguagem artística. A irracionalidade da guerra excitou os artistas e o mesmo ocorreu com Modigliani.

\footnotetext{
108 Intuição é a faculdade ou ato de perceber, discernir ou pressentir coisas, independentemente de raciocínio ou de análise. Forma de conhecimento direta, clara e imediata, capaz de investigar objetos pertencentes ao âmbito intelectual, a uma dimensão metafísica ou à realidade concreta. Na teologia visão clara e direta de D’us.
} 
Modigliani buscou através da expressividade seus meios plásticos. Sua dimensão metafísica proveio do existencialismo e seu anseio metafísico pôde ser encontrado na mística judaica. Seu estilo foi único, autônomo, lúcido, performático e objetivo. Seu conteúdo e forma surgiram como a reação da procura no espaço da tela para transmitir a representação da impressão a sua volta, porém representando o seu próprio mundo interior, seus próprios sentimentos. Sua linha carregou um movimento de preenchimento do vazio. Sua cor usou da motivação carregada de calor, criando as rupturas da arte moderna com uma nova forma de captar a existência, apresentando imagens além da realidade aparente, que refletiram o imutável, o eterno, o sensível humano e a natureza. Assim, Modigliani expressou em sua obra um processo de transmutação que retirou a cristalização do formalismo.

Ao conhecer a arte africana com alguns de seus colegas artistas, no início do século XX, Modigliani apercebeu-se dela de forma diferenciada, pois sua base era a da arte italiana, o que o fez ver um conteúdo além do tribal de forma e conteúdo ancestrais.

Modigliani buscou um método de investigação para a compreensão de informações artísticas/psicológicas obtidas gradualmente numa disciplina científica, elaborada ao se acrescentar o desenvolvimento de técnicas e estilos. Sua obra tem um único objetivo: compreender a natureza dos conhecimentos funcionais, com vistas a superar a impotência que caracteriza a instrução a respeito de fatores desconhecidos, fora do entendimento humano (BORDIEU, 1989).

Ao analisar a obra de Modigliani vem à mente associações com suas aspirações, angústias, sonhos e fantasias, com especial interesse nas experiências vividas em análise. $\mathrm{O}$ artista tentou manter uma atitude empática de não julgamento, visando a criar 
um ambiente seguro, de originalidade de conceito, introduzido pela proposição de uma realidade psíquica, característica do processo inconsciente ${ }^{109}$.

Ao analisar o contexto, observa-se que sua proposição estabeleceu um diálogo crítico às proposições da psicologia da arte tendo como objeto a consciência entendida na perspectiva da época. Observar a obra de arte que habita no consciente e no inconsciente, não é possível abordar diretamente o que conhecemos, mas somente informações e sintomas diversos expressos na sociedade, nas referências interpretativas, como meio mais simples e base mais sólida da vida.

A dimensão da consciência indicou um modelo que aparece instituidora, de significado, como receptor de toda significação. A grande ideia de conjuntura de liberdade de associação e ação criou um modelo na mente de Modigliani baseado no papel central e dinâmico do momento da criação. O contato com a realidade colocou em evidência uma interdisciplinaridade de abordagens, com diferentes planos de abstração, conceituações conflitantes e distintas linguagens. Este entendimento abarcou um contexto histórico e cultural na relação das próprias características do sistema e do modelo.

A lógica do sistema artístico europeu baseado na imitação das aparências - sistema que começara a ganhar corpo já no século XIII fora levado aos limites pela recente aceleração das transformações culturais. Num certo sentido, ela havia desmoronado. As grandes inovações que levaram aos vários novos sistemas que acabamos de notar - a matriz de contradições a que hoje chamamos "modernismo" - foram caracterizadas neste ínterim e passaram de capital a capital, fazendo uma entrada notável do outro lado do atlântico... (BELL, 2008, p. 383).

Os artistas na Paris efervescente no inicio do século XX tomavam conhecimento de uma fonte acadêmica, figurativa, e do não acadêmico estilo abstrato. Viam e

\footnotetext{
${ }^{109}$ Inconsciente é o momento que não pertence aos fenômenos vividos ou o processo ou conjunto de processos de vivência interior que influência o comportamento, chamado também de processo psíquico.
} 
produziam obras, indo de uma galeria à outra, frequentando ruas cheias de lojas com o verdadeiro glamour parisiense da época.

Na obra de Modigliani há uma clara expressão da vanguarda; sua técnica acompanha a avant-garde. Seus motivos, retratos e nus sublinham com força o caminho do contorno, das linhas fluidas. Seus espaços se formavam com conteúdos de justaposição, com planos de cor. Os retratos, de grande introspecção psicológica, apresentam características que poderiam ser compreendidas como deformação, mas sua transmissão é nítida: ele parece buscar os mistérios do retratado. Da mesma maneira, suas esculturas simétricas, alongadas e frontais, buscavam aproximar o observador de algo enigmático.

Modigliani realizou sua produção em estúdios/ateliers. Sentia-se em um templo, pois seu trabalho era sacerdotal; sua criação era divina; sua obra era ritualística. Ele viveu o momento do cavalete: seu atelier foi um templo e seu cavalete foi seu altar! Suas pinceladas sobre o suporte foram assinaturas; sua observação foi ontológica; seus saberes se constituíam no momento mágico da criação.

$\mathrm{Na}$ pintura, sua técnica foi historicamente tradicional, consistia em aplicar pigmentos em forma pastosa, líquida, sobre uma superfície, geralmente tela (óleo sobre tela). Ao produzir sua própria tinta realizava certa alquimia, utilizando a pedra/pó e seu aglutinante a fim de colorir, criando matizes. A substância aglutinante sobre um suporte, característica da obra de Modigliani, envolvem sua preferência pessoal, que não disponibiliza todo o conhecimento ao observador.

Suas representações definiram elementos fundamentais na questão da cor, pois a relação das massas coloridas presentes nas obras constituem o guia do olhar; sua explicitação figurativa foi a base da imagem. 
Modigliani foi fiel à pintura e não aderiu à gravura, à fotografia ou à colagem. Sua expressão visual era anímica. Sua realidade foi natural e sensível, porém interna. Sua obra foi essencialmente a representação pictórica de um tema.

O desenho, em Modigliani, existe antes da pintura e foi um suporte ligado à produção que envolveu uma atitude em relação à realidade sensível, transformadora, para criar uma nova realidade com as características expressivas que incluíram aspectos que podem ser pensados como religiosos, que possuem uma alma. Seu desenho pode ser pensado como um ritual místico, como um elemento fundamental da criação artística/espiritual, um instrumento para se chegar à obra final e em sua sistematização. Nos desenhos ele aplicou palavras escritas em hebraico, a escrita sagrada dos judeus.

Em suas obras estão em evidência a reflexão intensa e ternura pelos menos favorecidos. A escolha de temas e modelos demonstra essas preocupações. Desse modo, surgem em suas obras: a filha da encarregada do prédio, crianças fracas, belas moças do povo. Acompanha essas obras o poder do traço primitivo, especialmente a Arte Africana, presente também em vários momentos das vanguardas do início do século passado. Tampouco escapam as suas procuras, os ganhos e a expressividades dos traços orientais, como são exemplificados no retrato de Diogo Rivera, do MASP, presente na mostra do Museu Luxemburgo ${ }^{110}$ (AJZENBERG, 2011, p. 113).

O desenho de Modigliani era automático, como podemos perceber pela Figura 28, como num processo de grafomania entóptica ${ }^{111}$, em que o tema do desenho é o próprio papel como um todo. A relação com o resultado está na manifestação evidenciada pelo seu gesto e pelos movimentos do raciocínio visual. Suas linhas delimitam os objetos. Sua intenção era explicitar o contato na complexidade da etapa do

\footnotetext{
${ }^{110}$ O Musée du Luxembourg (Museu do Luxemburgo) foi o primeiro museu francês aberto ao público, em 1750. Em 1818, tornou-se o primeiro museu de arte contemporânea. A Exposição "Modigliani, l'ange au visage grave", ocorreu neste museu de 25 outubro de 2002 a 02 março de 2003. Catálogo realizado por Marc Restelli.

${ }^{111}$ Entóptica é o fenômeno visual que se observa no interior do olho, provocado por estímulos que não a luz.
} 
que pretendia sua representação com suas texturas que não incorporavam o matizado, que não possuíam gradação de tons, que detinham valores organizados a partir de uma fonte de luz e sombra que não acentuava a percepção de volume e tridimensionalidade, caracterizando formas, figuras e espaços de relações compostas para evidenciar apropriada e exclusivamente o refinado a ser designado.

Figura 28: Modigliani - "Diego Rivera", 1916, ospp, $100 \times 79 \mathrm{~cm}$, MASP

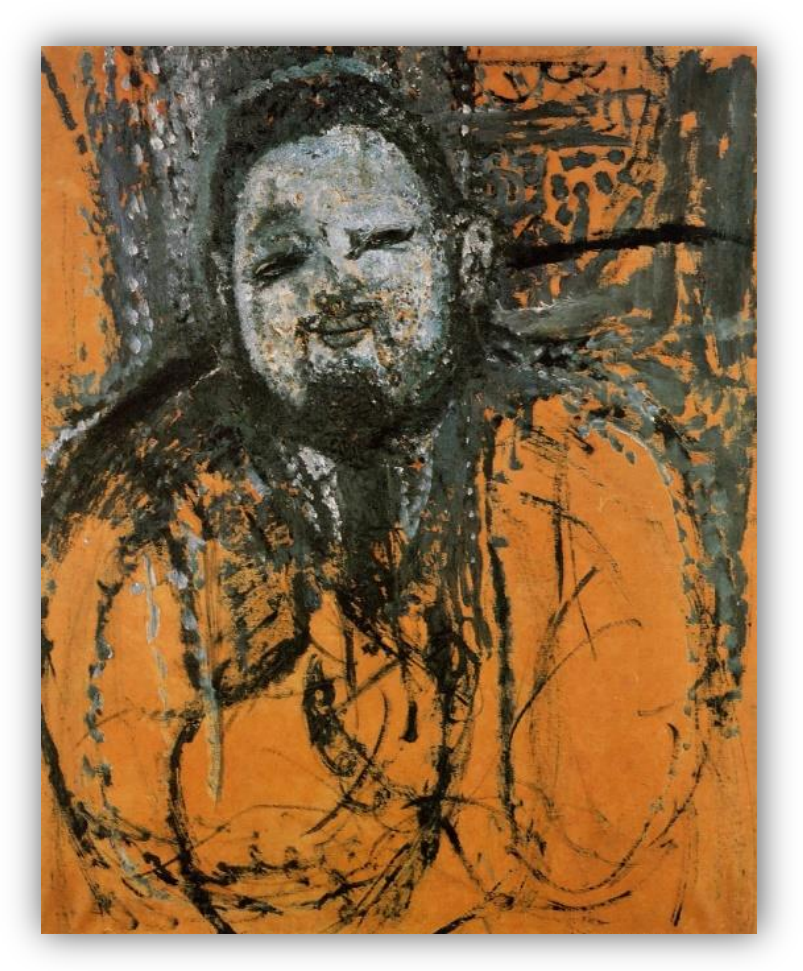

Fonte: CHATEAUBRIAND, 2008, p. 124.

Quanto às esculturas, Modigliani trabalhava a cinzelação para a criação de um não objeto. Criações perenes que representam a divindade numa forma antropomórfica através de materiais duráveis, porém acessíveis, tais como pedra calcária e granito. A forma idealizada não era efêmera e a escolha do cinzelamento tinha por objetivo atingir o efeito da sensação, do tempo perene, do poderoso representar do desgaste humano. As 
esculturas e pinturas de Modigliani representam a tal ponto a sentimentalização da existência humana que atingiram cifras nunca antes imaginadas na História da Arte.

A conscientização ${ }^{112}$ do objeto, em sua mente ${ }^{113}$, que a posteriori foi transportada para fora na manipulação da matéria, existe no mundo imaterial, no pensar do artista, habitando em diferentes níveis de consciência:

As imagens podem ser conscientes ou inconscientes. Cabe notar, porém, que nem todas as imagens que o cérebro constrói se tornam conscientes. Há imagens demais sendo geradas e competição demais para a janela da mente, relativamente pequena, na qual as imagens podem se tornar conscientes - ou seja, a janela na qual as imagens são acompanhadas da percepção de que as estamos apreendendo, em consequência, de que estamos atentando devidamente para elas. Em outras palavras, metaforicamente, existe de fato um subterrâneo sob a mente consciente, e esse subterrâneo possui muitos níveis (DAMÁSIO, 2015, p. 256-257).

O mundo imagético e as representações são expressões particulares ou sociais que apresentam evocações: resgate voluntário da memória, recordação. Com isto, causando uma transferência de reprodução mental ${ }^{114}$, percepção $^{115}$ ou sensação ${ }^{116}$ anteriormente experimentada. Neste momento da criação, surge a conscientização de suas visões:

\footnotetext{
${ }^{112}$ Conscientização é a tomada de consciência da natureza das relações humanas dentro do sistema e da sociedade em que se vive a experiência da relação explorado/explorador.

${ }^{113}$ Mente é a parte incorpórea, inteligente ou sensível do ser humano (DORIN, 1978).

${ }^{114}$ Mental é um conjunto de manifestações como crenças, maneira de pensar, disposições psíquicas, morais e etc., que caracteriza uma coletividade, uma classe de pessoas ou um indivíduo, chamado também de personalidade.

${ }^{115}$ Percepção é a consciência de alguma coisa ou pessoa, impressão ou intuição, experiência. Faculdade de apreender por meio dos sentidos ou da mente.

${ }^{116}$ Sensação é o processo pelo qual um estímulo externo ou interno provoca uma reação específica, produzindo uma percepção.
} 
Uma das pretensões da arte moderna, sobretudo da poesia moderna, é apresentar-se como um conhecimento de realidades ocultas, não imediatamente acessíveis. Contudo, se os poetas antigos consideravam-se veículos de um poder sobrenatural, pois um deus ou um demônio é quem se punha a falar com a voz do poeta, os poetas modernos admitem extrair visões do invisível de dentro de si mesmos. Elas são suas visões (FRAYSE-PEREIRA, 2006, p. 205).

A vida de Modigliani e sua relação direta com a tradição judaica e principalmente com sua mística, a Cabala, municiaram-lhe para representar esse seu mundo de signos e símbolos em suas realizações artísticas.

Entre os pertences de Modigliani, encontramos cadernos com desenhos de estudos cabalísticos, como o da Figura 29, que elucida sua compreensão sobre os ensinamentos de seu avô materno, Isacco.

Figura 29: Modigliani - "Estudo da Cabala Astrológica", 1909, 1sp, 30 x $17 \mathrm{~cm}$, caderno de desenho

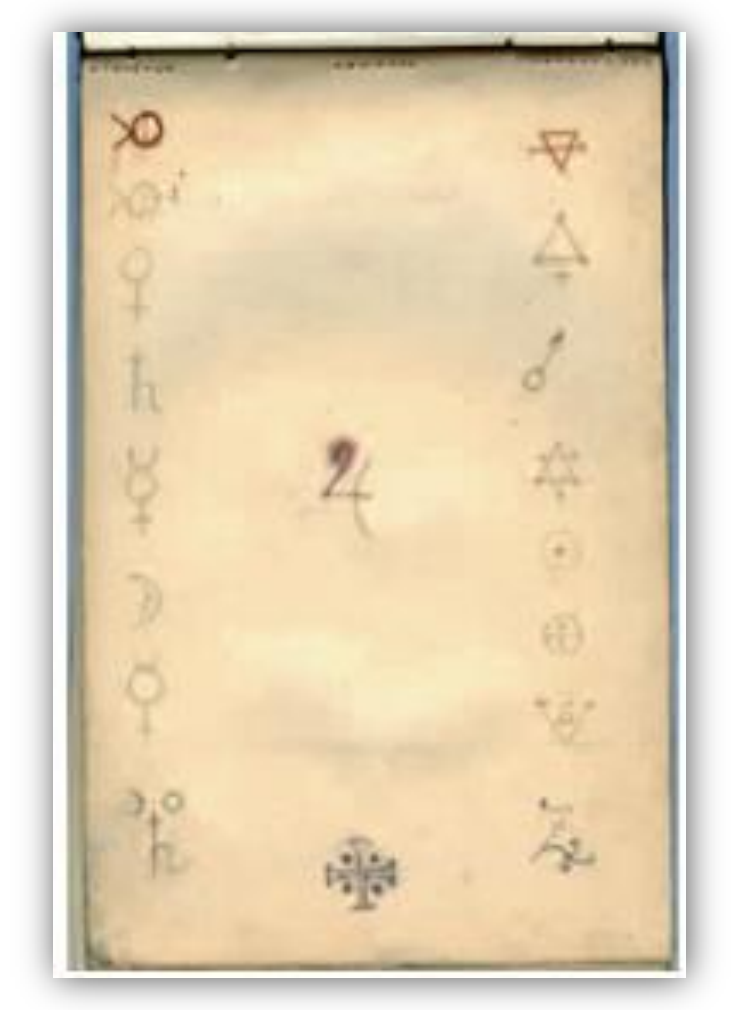

Fonte: Modigliani Institut, Roma. Foto do autor, 2011. 
Modigliani reconhecia-se plenamente como judeu. E, na tradição, um judeu não deixa de sê-lo simplesmente por não rezar (não frequentar a sinagoga ${ }^{117}$ ), ou não cumprir o Shabat ${ }^{118}$. Portanto, ser um artista em seu tempo, ou seja, vivenciar o mundo dos bares e afins, consumir bebidas e circular pelo universo das mulheres, na época chamadas de "mulheres da vida", não afetaria, de forma alguma, suas profundas tradições (SCHOLEM, 1989). Elas acrescentariam outros conteúdos que dariam forma à grande parte de sua arte.

Com o nascimento de sua filha, Jeanne, em 1918, Amedeo pediu ao seu amigo, astrólogo ocultista suíço, Conrad Moricand (1887-1954), conhecido também pelo nome Téricand, para fazer o mapa astrológico cabalístico da recém-nascida (Figura 30). Tal fato apresenta sua natureza mística; pois se acredita que o mazal (astro) exerce influência sobre as pessoas, haja vista que a forma de desejar boa sorte é: Mazal Tov ${ }^{119}$.

\footnotetext{
${ }^{117}$ Sinagoga é o lugar onde se reúnem os judeus para o exercício do seu culto religioso.

118 Shabat é o período religioso utilizado para a reza do judeu. Inicia-se no ocaso da sexta-feira e termina no ocaso do sábado.

${ }^{119}$ Mazal Tov significa "boa sorte", porém, a palavra mazal significa "gota do alto". Deste modo, pode-se ter diferentes conotações, em diferentes contextos, mas, de uma forma geral, significa "algo caindo de cima".
} 
Figura 30: Moricand - "Mapa astrológico de Jeanne Modigliani", 1918 , 1sp, 30 x $22 \mathrm{~cm}$

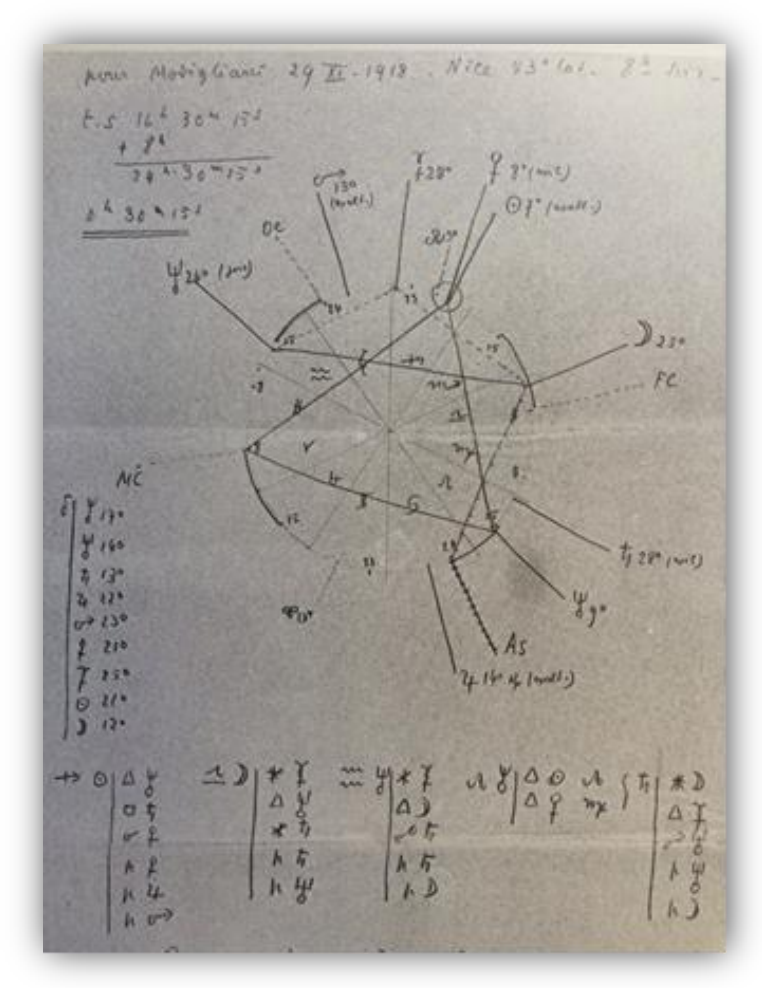

Fonte: MODIGLIANI, 1984, p. 134.

Moricand desenvolveu, junto com Modigliani, vários estudos cabalísticos, com aprofundamento na escrita hebraica. Ele foi retratado algumas vezes por Modigliani (Figura 31). A amizade profunda dos dois acabou se consolidando com a morte de Modigliani, pois foi ele quem ajudou a realizar sua máscara mortuária. 
Figura 31: Modigliani - "Conrad Moricand", 1916, ost, 22 x 17 cm, coleção particular

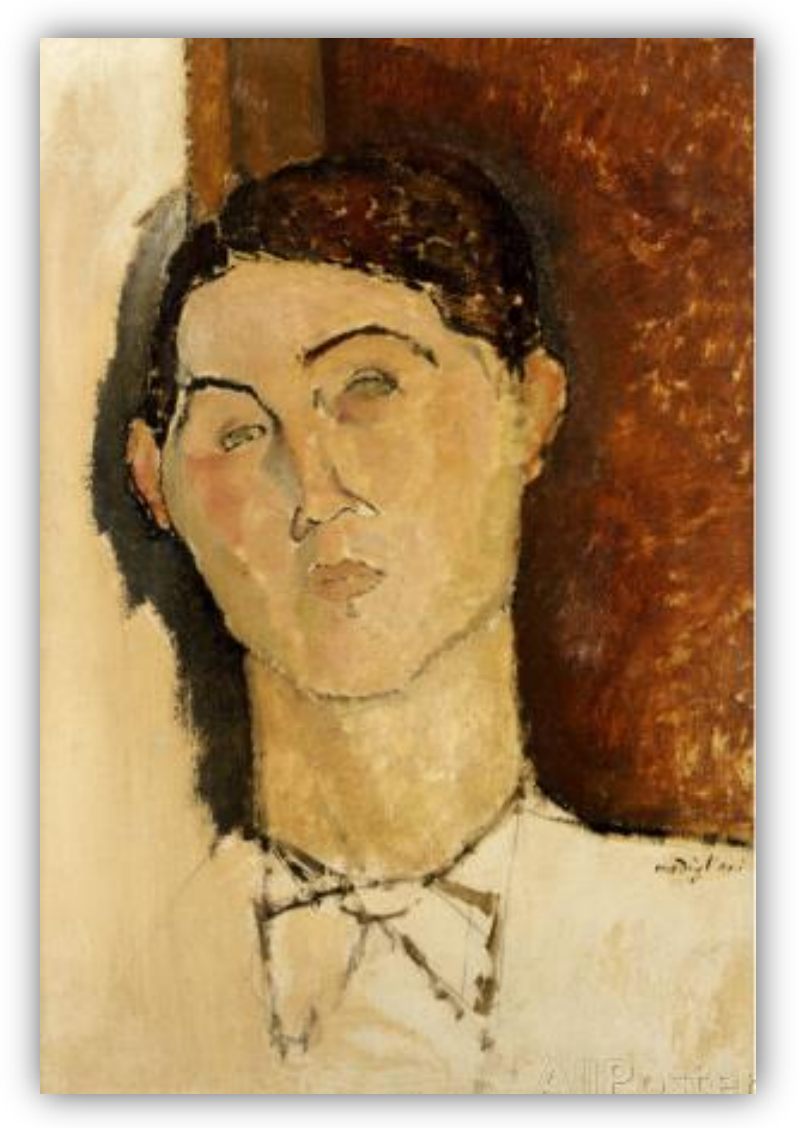

Fonte: TSANEVA, 2014, p. 23

O mais profundo ocultismo, a base da religião, das sociedades secretas e da filosofia, existe no ato de receber o contato com o divino, a ligação com $D^{\prime} u s$. O substantivo Cabala traduz-se por "receber": receber a luz divina!

\subsection{Da Cabala à Arte}

A interpretação da obra é feita a partir da intuição e existe na ignorância sábia. As interrogações e as pendências são constituídas de dentro para fora, de fora para dentro, do interior para exterior e do exterior para interior e, assim, o artista é criador, é 
inspirado quando executa; e é criatura, quando observa a criação, momento em que a obra adquire a presença implicada.

O mundo não é um objeto do qual possuo comigo a lei de constituição; ele é o meio natural e o campo de todos os meus pensamentos e de todas as minhas percepções explícitas. A verdade não "habita" apenas o "homem interior", ou, antes, não existe homem interior, o homem está no mundo, é no mundo que ele se conhece. Quando volto a mim a partir do dogmatismo do senso comum ou do dogmatismo da ciência, encontro não um foco de verdade intrínseca, mas um sujeito consagrado ao mundo (MERLEAU-PONTY, 1999, p. $6)$.

Da unificação destes conteúdos perceberemos que nas obras de Modigliani deitam toda a história de um conhecimento consciente e inconsciente no qual a inspiração ${ }^{120}$ faz criar algo que representa seu mundo simbólico e todo o conteúdo de uma vida vivida e de tradições (DORIN, 1978). Os primeiros trabalhos de Modigliani, que unificam estes conteúdos, são os desenhos realizados quando morava em Paris. Fica evidente que Modigliani era um judeu convicto. Além de ter cadernos apropriados para seus desenhos ${ }^{121}$, ele demonstrava sua obsessão pelo desenho utilizando livros antigos (em alemão, francês ou italiano) como suporte para seus estudos de conhecimentos cabalísticos e de tradição sefardita. Estes livros, com seus comentários manuscritos, podem explicar o uso da geometria no rosto, nos olhos, na boca e no pescoço baseados na Árvore Sefirótica, que representa as sefirot do lado direito de quem observa a Figura 32, e do lado esquerdo as palavras: em cima Sefirot (ספירות), e em baixo Cabala (קבאל).

\footnotetext{
${ }^{120}$ Inspiração é o estado que a pessoa é estimulada pela capacidade criativa. Ideia súbita e espontânea, geralmente brilhante e/ou oportuna; iluminação, lampejo. Para os judeus, sopro divino que teria guiado os autores das Sagradas Escrituras (MARÍN, 1984).

${ }^{121}$ Os desenhos aqui apresentados fizeram parte da exposição intitulada: "Modigliani: Segno e Tradizione", realizada no Palazzo della Cancelleria, em Roma, de 26 março a 11 de abril de 2012.
} 
Figura 32: Modigliani - "Geometria e Cabala", 1908/?, tsp, 21 x $13 \mathrm{~cm}$, caderno de desenho

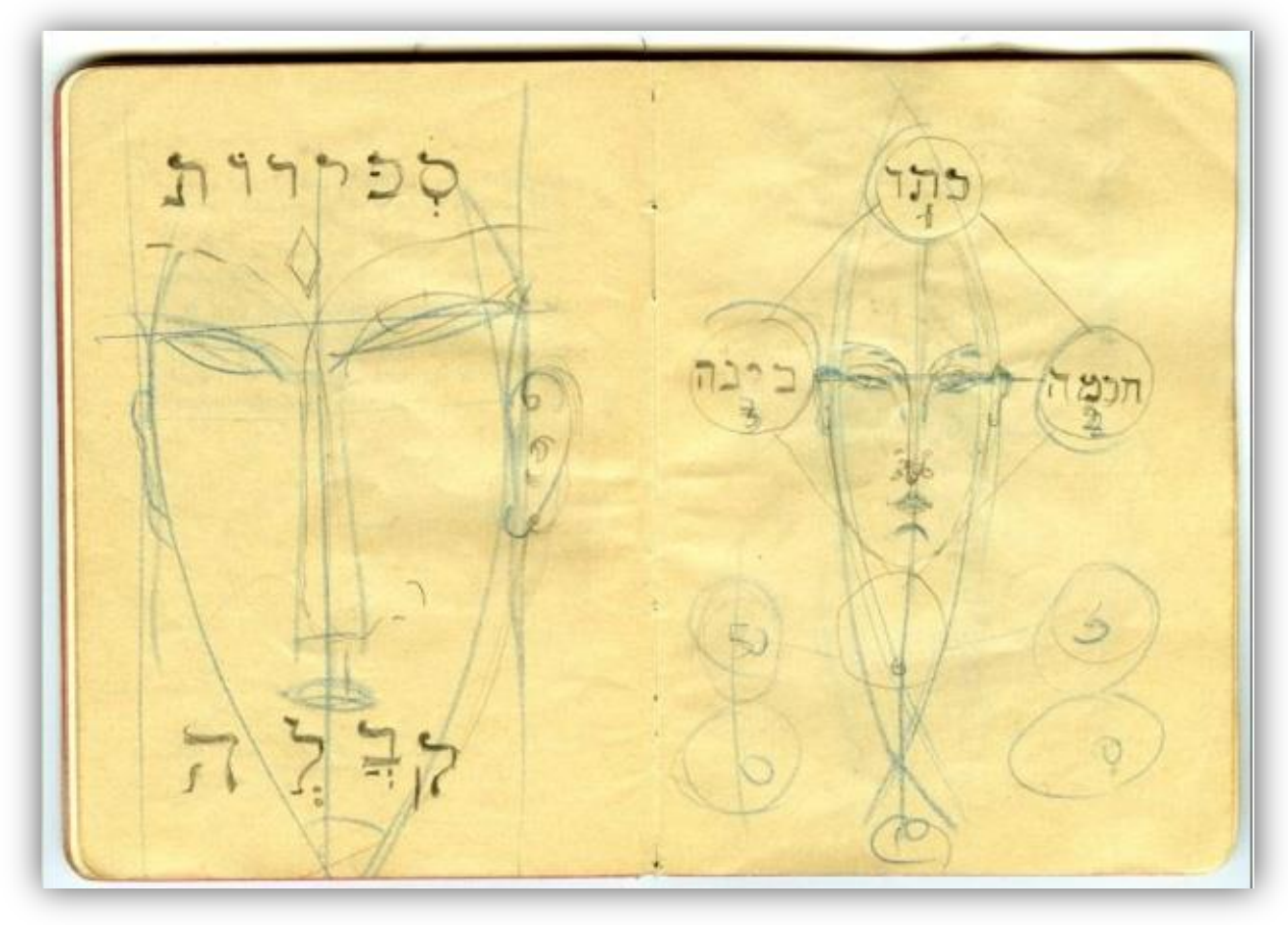

Fonte: Modigliani Institut, Roma. Foto do autor, 2017.

Talvez a solidão de Modigliani tenha lhe dado o desconforto necessário para que experimentasse seus estados interiores e, com isto, seu emocional ${ }^{122}$ acabou vivendo em plenitude, podendo realizar seu conteúdo interior (FRAYZE-PEREIRA, 2006).

Sua obra "A Judia" (Figura 33), de 1908, é a primeira na qual Modigliani introduz na pintura a forma longilínea. Esta obra expõe um ambiente escuro, um semblante solene, um olhar de expressão penetrante; o rosto contrasta fortemente com o fundo; uma luz derrama um estado de veracidade. Esta obra fez parte da exposição do Salon des Indépendants, em 1908, dada à importância que ele lhe atribuía.

\footnotetext{
${ }^{122}$ Emocional é a reação orgânica de intensidade e duração variáveis, geralmente acompanhada de alterações respiratórias e de grande excitação mental que provoca comoção, despertando sentimentos intensos.
} 
Figura 33: Modigliani - "A Judia", 1908, ost, 55 x 46 cm, Museum Kamagawa

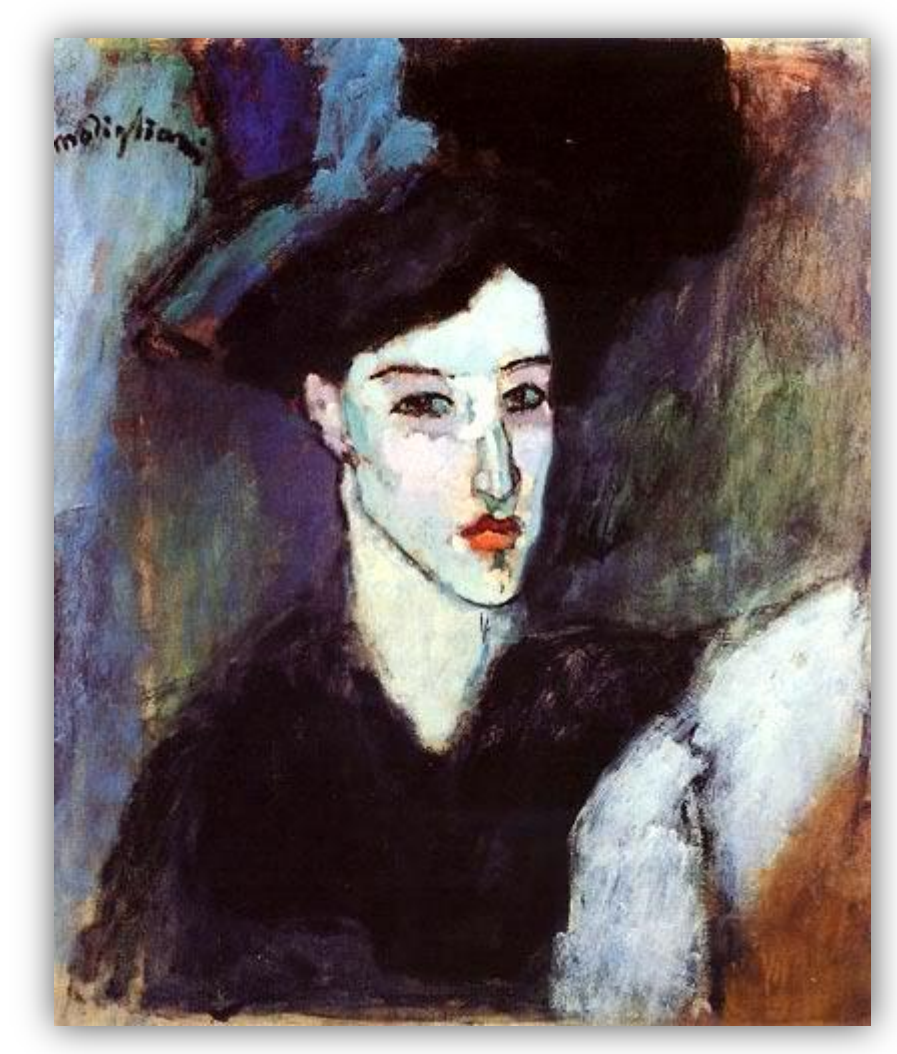

Fonte: GALLAND, 2005, p. 37

Até os 22 anos de idade, Modigliani morou com uma família sefardita, de modo que todos os anos eram realizadas festas judaicas, sem deixar passar o $\operatorname{Seder}^{123}$ de Pessach $^{124}$, que se refere ao jantar cerimonial judaico, à Páscoa judaica ou à Festa da Libertação, quando se revive a história do Êxodo, a partida do momento em que o povo hebreu deixou para traz a escravidão no Egito, ligado a sua fé em seu $D^{\prime} u s$.

\footnotetext{
${ }^{123}$ O Seder é o serviço ritual e jantar cerimonial da primeira noite ou das duas primeiras noites do Pessach.

${ }^{124}$ Pessach, do hebraico como Festa da Libertação, que celebra a libertação dos hebreus da escravidão no Egito, aproximado de 1440 a.C.
} 
O jantar é revivido de forma totalmente cerimonialista, segundo a Hagadá ${ }^{125}$, principalmente na keará, que é o prato utilizado para apoiar os sete símbolos ${ }^{126}$ de rememoração, todos de profunda representação religiosa. No nosso objeto de estudo, o zeroá é especialmente significativo. Trata-se de um pescoço de frango, que representa o sacrifício da passagem, o Pessach. Ele não é comido, pois seu simbolismo indica a passagem do cérebro para o coração e do coração para o cérebro, ou seja, do sentimento para a consciência. Esta tradição milenar, revivida por Modigliani desde seu nascimento, foi inserida de maneira sutil em suas obras. Este ritual poderia ser simplesmente um relembrar, porém, em se tratando de uma família sefardita, com um avô como Isacco Garsin, religioso e profundo conhecedor da Cabala, este conhecimento tornou-se sabedoria, ou seja, viveu e reviveu em seu interior no caminho para $D^{\prime} u s$.

Este simbolismo da passagem nos é apresentado na obra de Modigliani como representação de um estado inferior para um superior, onde os pescoços longilíneos, tanto nos desenhos, como nas esculturas ou nas pinturas é iniciático ${ }^{127}$, pois é através da fala que oramos e que nos ligamos ou religamos (religião) ao mundo superior.

No capítulo anterior, quando analisamos a questão da gematria, mostramos como o alfabeto judaico é também enumerado, dando peso às letras. Assim, palavras não devem ser proferidas à toa. Toda a ressonância do som é realizada no pescoço, pois ele é o tubo da passagem do ar que tocará nossas cordas vocais possibilitando a emissão do som. Lembremos do shofar, instrumento de sopro feito do chifre de um animal

\footnotetext{
${ }^{125}$ A transliteração de Hagadá, do hebraico הדגה, significa narração. É o texto utilizado para os serviços da noite do Pessach, contendo a história da libertação do povo de Israel do Egito, descrito no Livro do Êxodo.

${ }^{126}$ Os sete símbolos que se apoiam na keará (prato) são o betsá: ovo cozido; zeroá: osso; maror: ervas amargas; karpás: cebola; charósset: amêndoas, tâmaras, canela e vinho; chazeret: ervas amargas e matzá: pão ázimo.

${ }^{127}$ Iniciático é aquele foi introduzido na prática ou no conhecimento, nas revelações, nos mistérios e nas práticas de um culto, de uma seita ou de uma ordem secreta.
} 
kasher $^{128}$, usado em ocasiões solenes. A palavra shofar é mencionada pela primeira vez na Revelação Divina no Monte Sinai, no recebimento dos Dez Mandamentos ${ }^{129}$. No Rosh Hashanah (ano novo judaico), o shofar é tocado para lembrar os judeus de suas obrigações religiosas. Estes envolvimentos com a respiração e com o sopro nos reportam à doença de Modigliani que o deixou recluso na infância e que foi também causador de sua morte.

Modigliani nasceu com problemas respiratórios e essa debilidade respiratória não era apropriada ao ato escultórico, mas nem por isso o impediu de se dedicar a escultura no período de 1909 a 1914, sobretudo em função de, em 1909, ter conhecido o escultor romeno Brancusi, que o fez reviver não apenas seu desejo de esculpir, mas sua vontade de se dedicar ao tridimensional. Neste período, ele produziu poucas pinturas. No entanto, teve que parar de esculpir devido a problemas de saúde, à pleurisia especificamente. Apesar de seu problema, nesses quatro anos de dedicação à criação do tridimensional, acabou deixando 27 esculturas. Neste período, ele também desenhou muito, criando uma manufatura potente que deu nova visão e realização a seu pintar, levando-o a criar seu próprio estilo.

A pintura de 1911, "Busto de uma jovem mulher" (Figura 34), é uma de suas raras pinturas deste período em que se dedicara à escultura. Percebemos a extrema ligação desta pintura com seus desenhos e esculturas. A posição da cabeça em relação ao pescoço, diafanamente, transparece-nos as sefirot e a canalização das emanações, o nome divino dentro da sefira com suas letras canalizadas emanando o conhecimento. $\mathrm{O}$ pescoço longilíneo deixa clara a influência cabalista das emanações canalizadas. Até então, nenhum outro artista havia desenvolvido esta forma/perspectiva.

\footnotetext{
${ }^{128}$ Kasher, kosher ou casher significa puro, apropriado. São as regras originárias da Torá e do Talmude sobre o comportamento social e alimentar do judeu religioso.

${ }^{129}$ Os Dez Mandamentos ou o Decálogo é o nome dado às leis bíblicas escritas por D'us em pedra, dadas ao profeta Moisés, conhecidas também como as Tábuas da Lei.
} 
Figura 34: Modigliani - "Busto de uma jovem mulher", 1911, ost, 55 x 38 cm, coleção Latterman

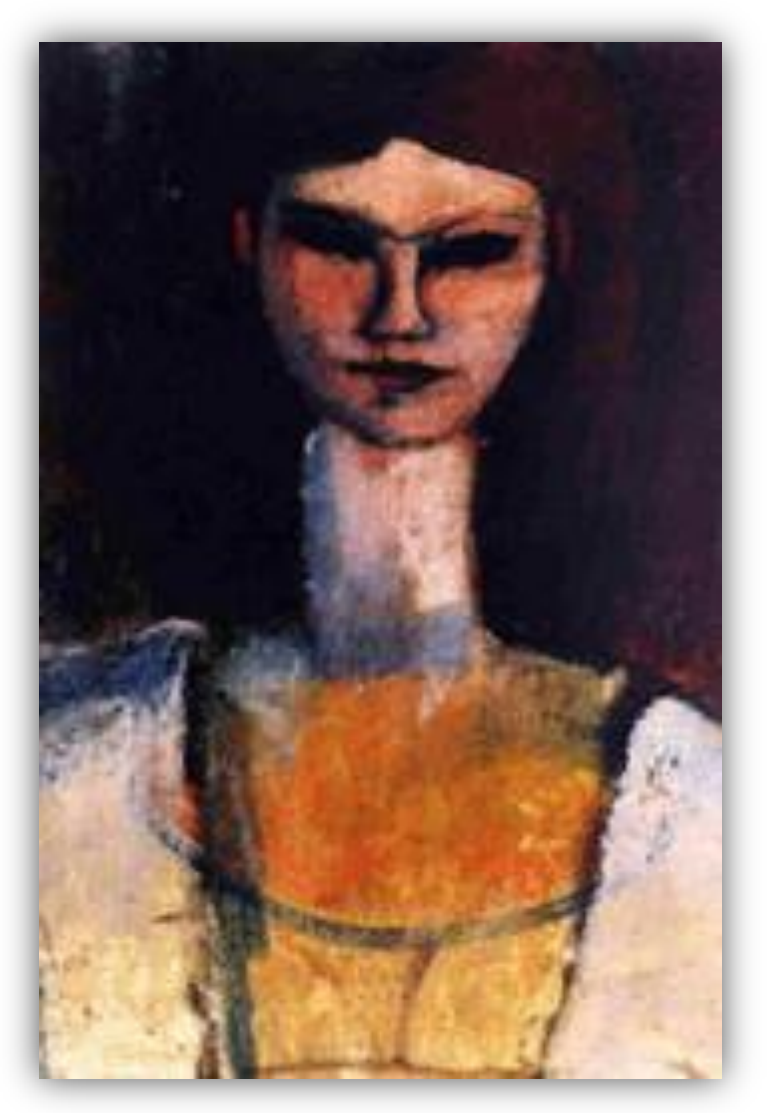

Fonte: GALLAND, 2005, p. 54.

Seu traço torna-se efetivo, forte, rápido. O escultor, em geral, detém conhecimentos mais profundos sobre o biótipo muscular, superior ao do pintor, pelo óbvio motivo de carregar o peso de seus objetos, no caso de Modigliani, a pedra. Assim, sua necessidade de teorizar para errar menos, o levou a desenhar muito. $\mathrm{O}$ ato de desenhar criou no artista uma realização impulsiva, pois se tornou manifesto, pleno; um ato com designação, portanto: representação, significação, classificação e qualificação. Não deve ser uma mera coincidência que o verbete designar detém em si à palavra 
‘signo', adentrando, assim, no mundo semiótico ${ }^{130}$, no qual reside o mundo cabalístico (IDEL, 2000).

Modigliani utilizou pedras calcárias ${ }^{131}$ (de calçada calcária) para suas esculturas, pedras-do-meio-fio (Figura 35), que detêm um formato de um longo paralelepípedo. Seu ato é de desbaste.

Figura 35: "Pedra do meio-fio", pedra calcária, fotografia

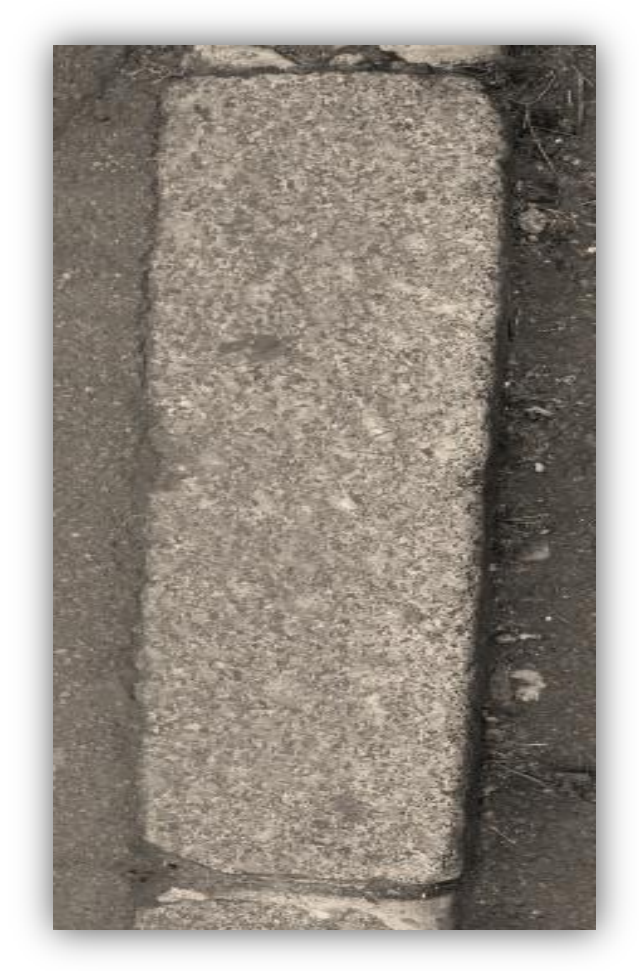

Fonte: Foto do autor, 2017.

O movimento no trabalho tridimensional de Modigliani (Figura 36) transmite instantaneamente um estado simbólico de criação, vindo de seu inconsciente e que utiliza este formato correspondente à "Árvore Cabalista", como pode ser observado nas

\footnotetext{
${ }^{130}$ Semiótica, segundo Charles S. Peirce (1839-1914) é a teoria geral das representações, que leva em conta os signos sob todas as formas e manifestações recíprocas entre os sistemas significantes que integram (NICOLA, 1982).

${ }^{131}$ Calcária é um tipo de rocha comum sedimentar constituída basicamente por carbonato de cálcio e de magnésio.
} 
Figuras 37, 38 e 39, simbolizando a descida da luz, ou seja, a iluminação do conhecimento de $D^{\prime} u s$, tal como está presente em seus desenhos nos cadernos e livros de estudos.

Figura 36: Modigliani - "Cabeza ${ }^{132, "}$ 1911/13, pedra calcária, 71,8 × 18,4 x 30,6 cm, coleção particular

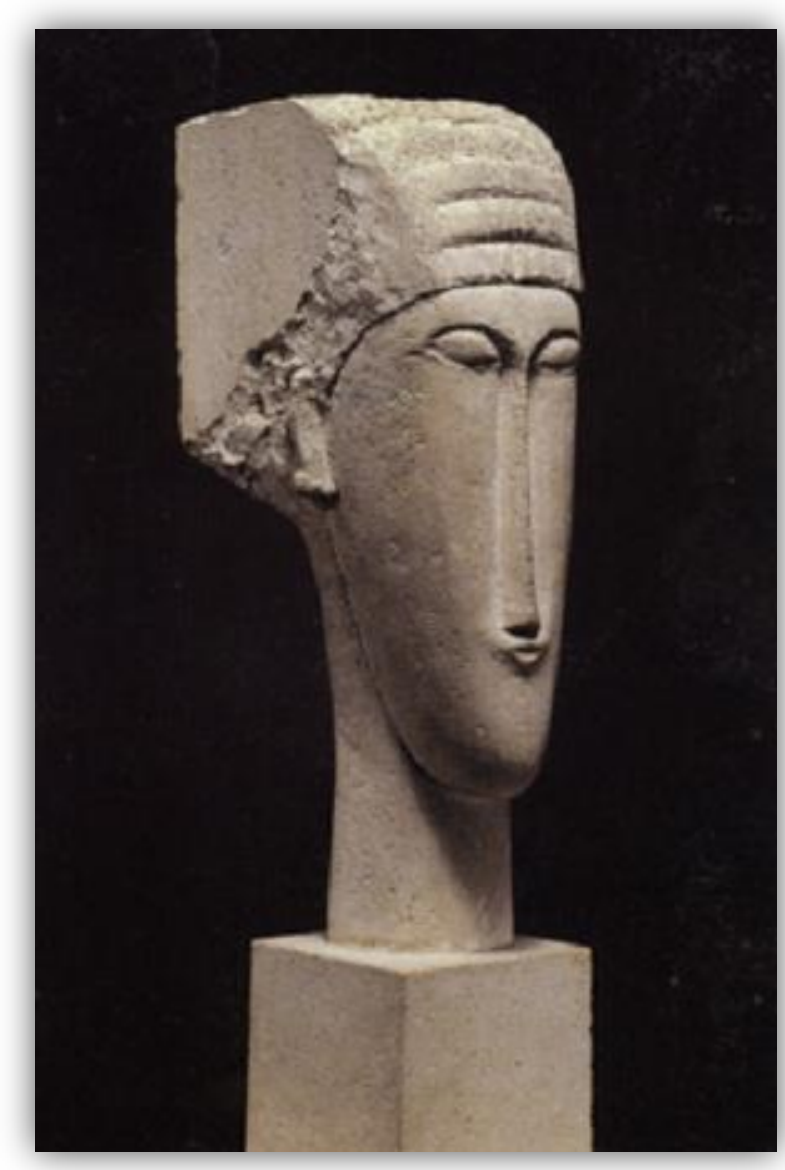

Fonte: GALLAND, 2005, p. 56.

132 Cabeça Tête foi a escultura de Modigliani que alcançou US\$ 52,6 milhões de dólares, em leilão realizado em Paris, em 2010. Foi um recorde para uma obra de arte comercializada na França. A obra foi realizada entre 1910 e 1912 em pedra calcária, medindo 65 centímetros de altura. É uma das dez únicas esculturas de Modigliani nas mãos de particulares. Pertencia à coleção de Gaston Levy, que a adquiriu em 1927. 
Figura 37: "As Sefirot", desenho

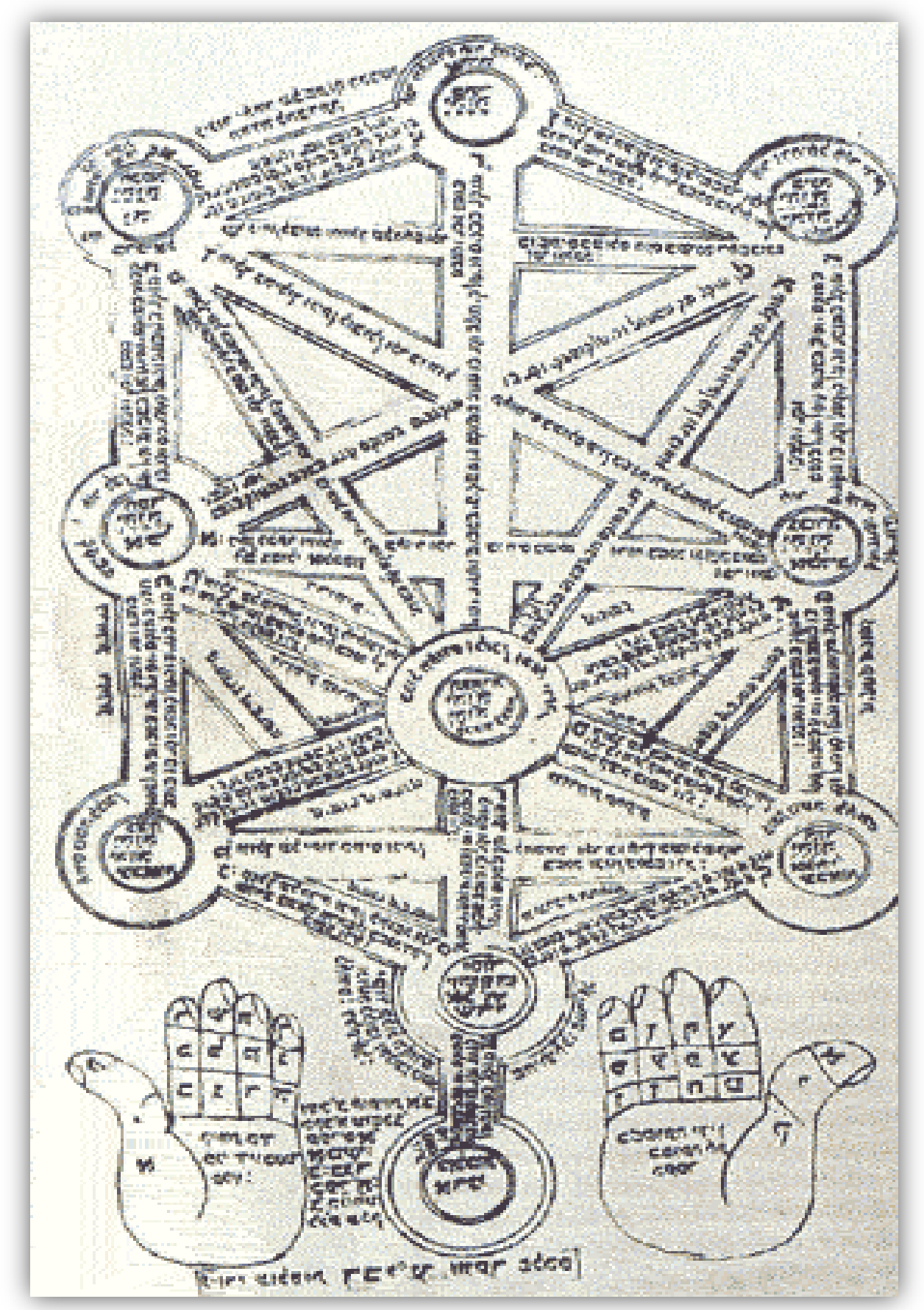

Fonte: ROOB, 2001, p. 316. 
Figura 38: “Árvore Cabalista”, desenho

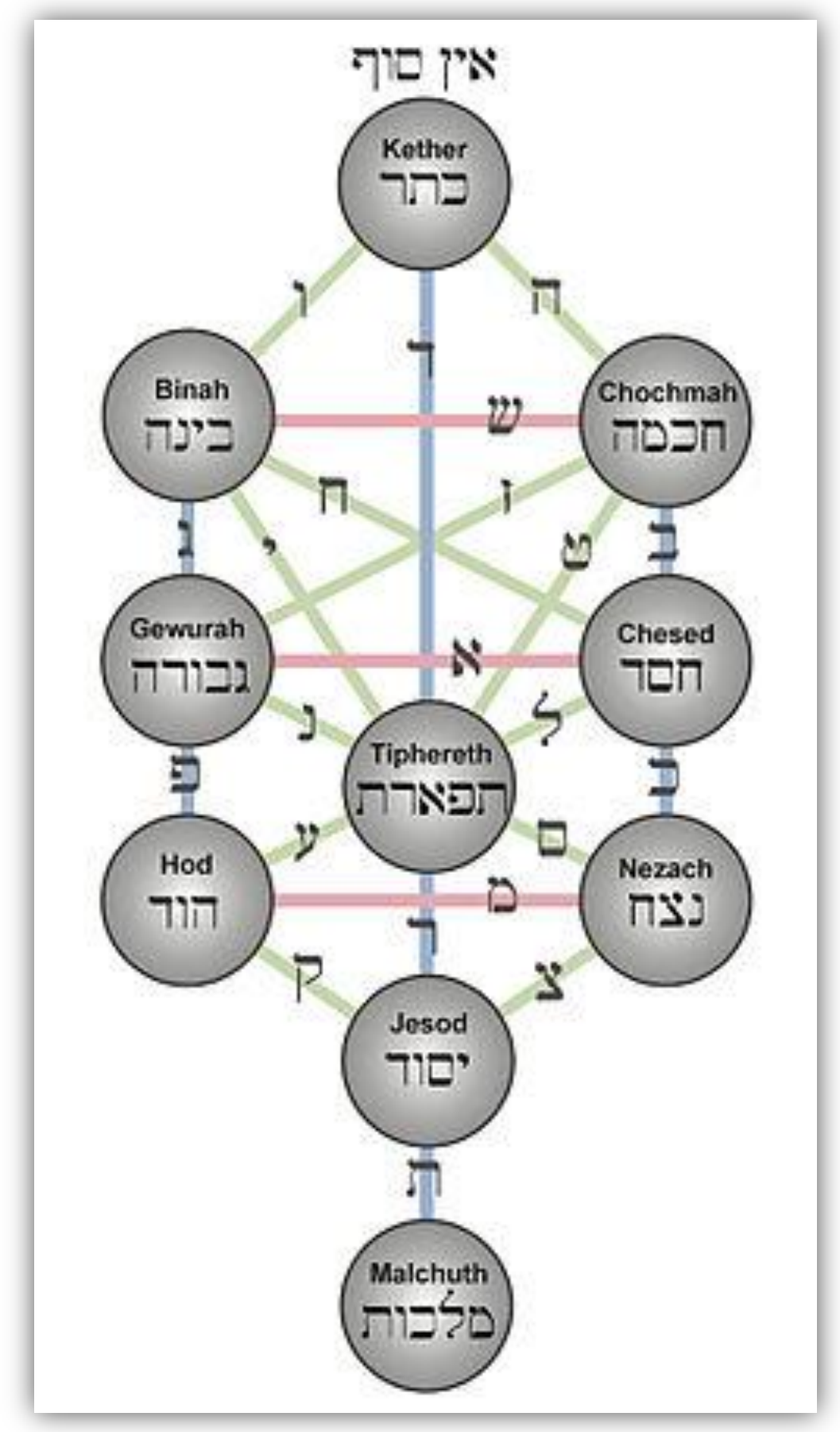

Fonte: KAPLAN, 2002, p. 56. 
Figura 39: "Árvore Cabalista", desenho (Detalhe)

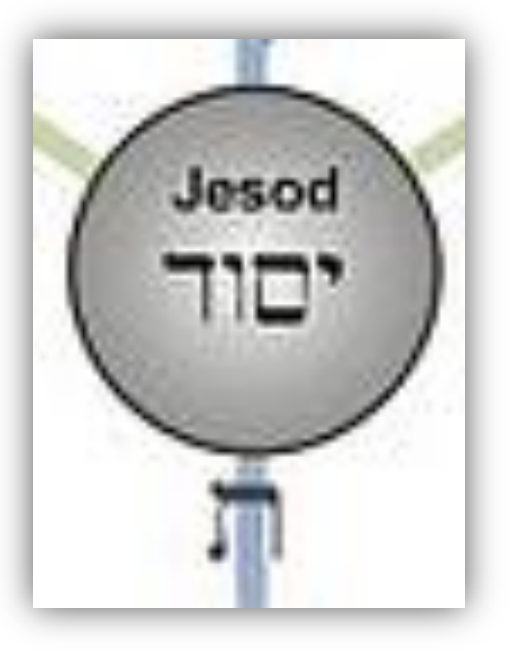

Fonte: KAPLAN, 2002, p. 56.

Em seus desenhos das cariátides, Modigliani demonstrou a ligação do misticismo cabalístico em sua arte, o mesmo que se apresentou em suas esculturas e, posteriormente, em suas pinturas. Sobre o desenho/pintura da cariátide (Figura 40), Modigliani sobrepõe a Árvore Cabalista. Estes círculos, as sefirot, têm suas ligações através dos 'condutores' que fazem as ligações entre si e que transmitem as 22 letras do alfabeto hebraico. Letras criadoras das palavras, simbolizando exatamente onde está a origem da fala, na caixa sonora: no pescoço, como já ponderamos anteriormente. 
Figura 40: Modigliani - "Busto rojo", 1913, osc, 81 x 46 cm, coleção particular

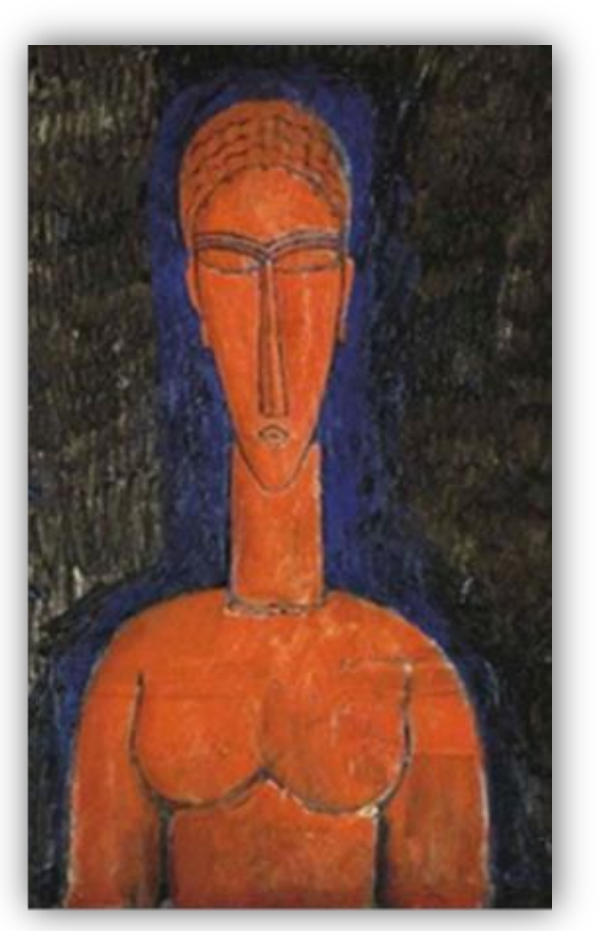

Fonte: GALLAND, 2005, p. 64

No desenho realizado por Modigliani, intitulado "Cabala Malchut" (Figura 41), podemos observar, do lado direito superior, cinco triângulos, significando os cinco sentidos, apontados para baixo, desenhados sobre a cabeça, como o símbolo que representa a condução das luzes, os caminhos das palavras de criação divina. A História da Arte demonstra que vários artistas utilizaram a forma triangular como símbolo de aura divina, a ponta para cima, a ascensão e, ao contrário, a descida ou ajuda. No extremo direito está a palavra Malchut (mundo), também escrita de cima para baixo, significando, com esse movimento e nesse momento, a emanação divina no mundo (SCHOLEM, 1989). 
Figura 41: Modigliani - "Cabala Malchut", 1908/?, lsp, 21 x 13 cm, caderno de desenho

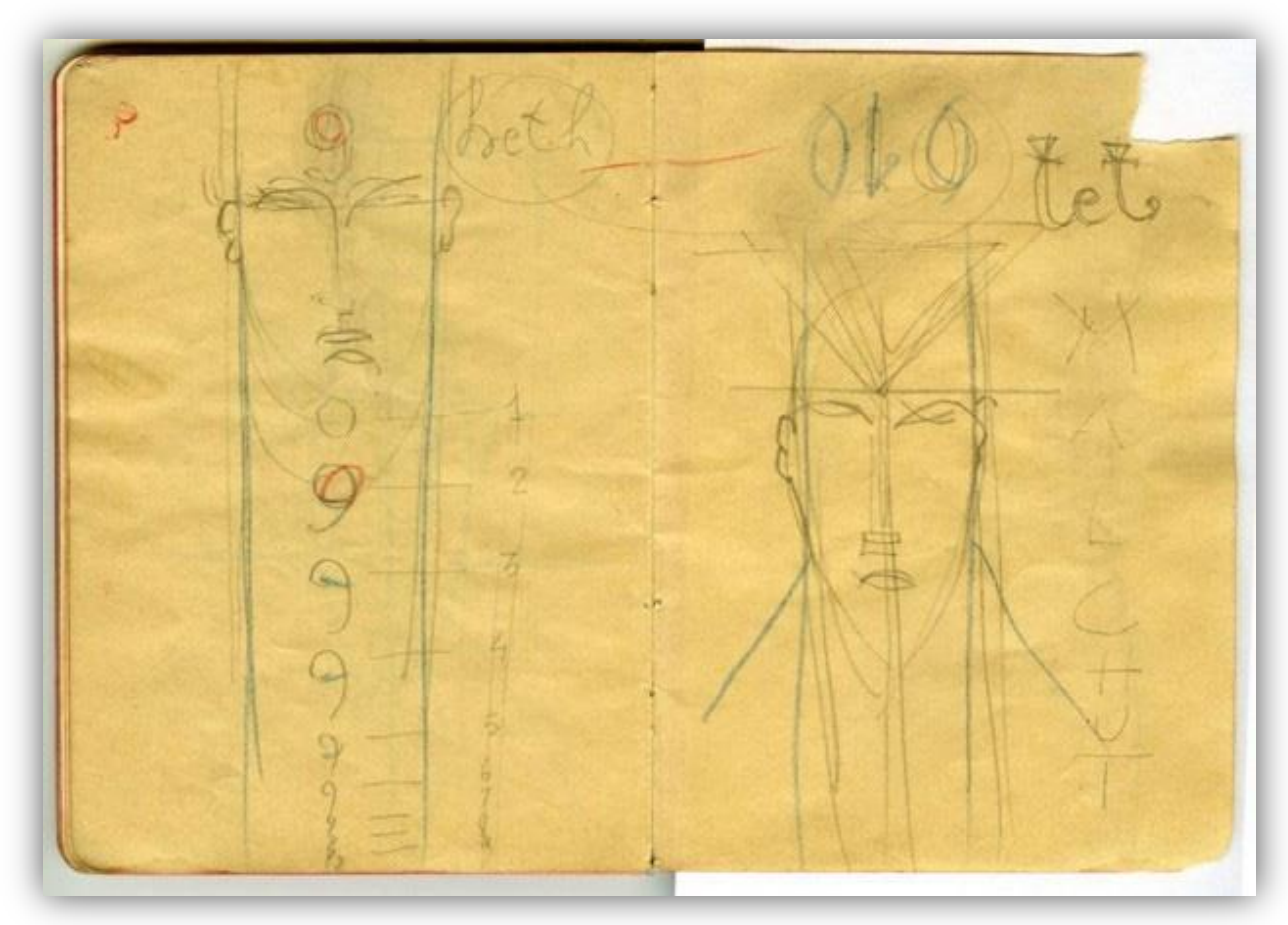

Fonte: Modigliani Institut, Roma. Foto do autor, 2017.

No mesmo desenho, a esquerda, esta uma representação longilínea do pescoço, equipara-se a canalização da Árvore Cabalista e, portanto, como os pescoços longilíneos desenhados, esculpidos e pintados por Modigliani. Sobre o mesmo desenho, podemos observar uma sequência de nove números noves, escritos de cima para baixo, simbolizando a descida da consciência, a descida da luz divina. O número nove, no judaísmo, representa a realização da divindade. Somando duas vezes o número nove, temos dezoito $(9+9=18)$ que representa o número da palavra vida em hebraico: pois é o somatório das duas letras, iud (10) e heth (8), que na gematria pesam 10 e 8 $(10+8=18)$, como explicamos no Capítulo 2, Figura 22. O número nove é também o somatório dos números $72(7+2=9)$, destacando que nas escrituras sagradas encontramse 72 nomes para $D^{\prime} u s$, o Criador, formados pela combinação de três letras em cada nome. Também constatamos a escrita da letra heth ( $\pi$ ) por extenso (canto superior 
esquerdo do observador) que, como já vimos, representa o número oito (8) e a letra teth (ט) também por extenso, lado oposto, que representa o número nove (9). Ao traduzirmos e interpretarmos a palavra malchut, temos a palavra mundo, que significa mundano, ou seja: próprio do mundo. No desenho, existem dois números noves em destaque, pintados em vermelho, um no cenho, entre os olhos, e o outro na garganta, representando o pensar e o falar, e o falar e o pensar, como observamos no Pessach, no keará (prato) em que está depositado o zeroá (osso, pescoço).

Em estado de imanência, as obras de Modigliani apresentam-se no âmbito da experiência do possível e do impossível. A análise da atividade escultórica de Modigliani apresenta o corte direto na pedra calcária. A escolha dessa pedra não foi aleatória. Modigliani e o amigo Brancusi não compartilhavam com o estilo de modelação de $\operatorname{Rodin}^{133}$. O corte direto pedia um suporte mais apropriado e a pedra calcária adequava-se à realização de sua obra pela elevação no rasgar, principalmente no talhe do nariz, como pode ser percebido na Figura 42. Sua produção deixa claro que seu objetivo era a sublimação através da pedra; a pedra como símbolo da base da construção utilizada na arquitetura, a Pedra Fundamental ${ }^{134}$, pensada em sociedades secretas como a "lapidação da pedra bruta" representando "o lapidar da alma".

Ao esculpir somente cabeças, Modigliani expressava o superior do vestido da alma (o corpo) e, também, a importância dessa representativa parte, indicando a consciência.

\footnotetext{
${ }^{133}$ François-Auguste-René Rodin (1840-1917) foi um escultor francês. Apesar de ter sido considerado progenitor da escultura moderna, não se rebelou contra o passado. Educado na forma tradicional, teve o artesanato como abordagem em seu trabalho. Tentou o reconhecimento acadêmico, mas nunca foi aceito na Escola de Arte de Paris.

${ }^{134}$ A Pedra Fundamental corresponde a uma pedra inicial e de grande importância, assentada na base de uma construção, a primeira de uma obra. Também significa cerimônia de inauguração, de início de uma construção.
} 
Figura 42: Modigliani - "Cabeza", 1912, pedra calcária, $58 \times 12 \times 16 \mathrm{~cm}$, Centre Pompidou

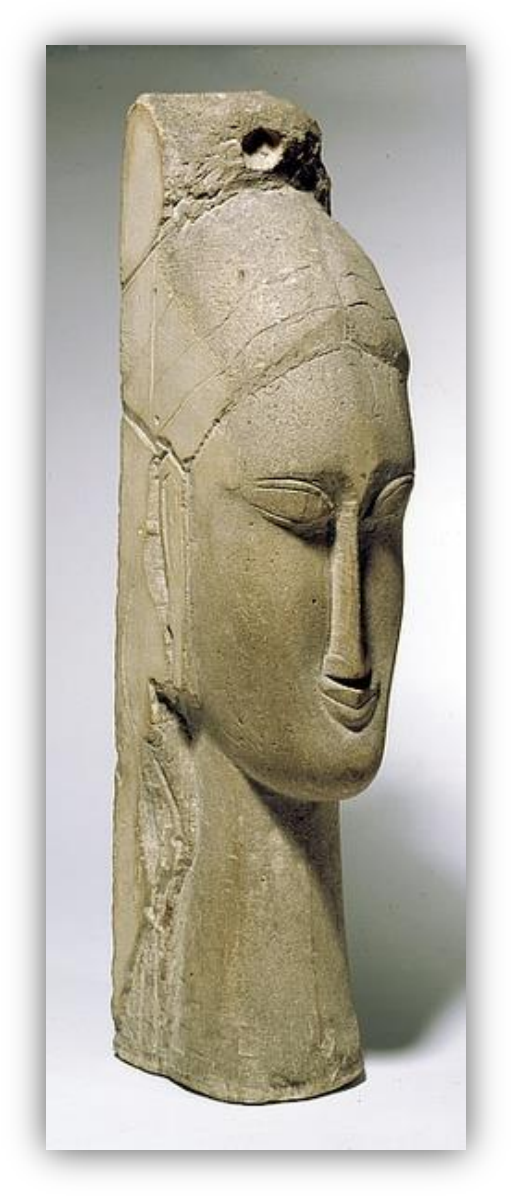

Fonte: GALLAND, 2005, p. 60.

Quando se instalou na Rue Cité Falguière, no bairro de Montparnasse, em 1909, Modigliani se debruçou sobre o ato de desenhar, designando assim seu preparatório mental para o corte na escultura, corte feito como um fio de navalha, objetivo e certeiro. Durante esses anos (1909-1914), Modigliani se apresentou como escultor, buscando a arte africana, muito pesquisada e interpretada no início do século XX por tantos artistas. Para os africanos, a máscara representava o mundo místico que absorvia forças mágicas dos espíritos e, assim, servia como fonte de poder na cura, nos rituais fúnebres, nas cerimônias de iniciação, nos nascimentos e nos casamentos. Cabe lembrar a estatuária egípcia e seu culto à morte, à iniciação e à ascensão da alma. 
Ao escolher blocos retangulares de pedra calcária, Modigliani revelou seu senso de espacialidade. Seus gravados apresentam os olhos, abertos e fechados, as pálpebras cerradas que nos transmitem simbolicamente o contato com o eu interior, a mística na busca do divino, a contemplação. Seu estilo principal, longitudinal no corte do nariz, indica a orientação da energia da criatividade, pois abaixo e entre os olhos desce a narina, simbolizando o despejar da luz, a consciência da existência humana, dando sequência e apoio à linha do pescoço, o formato longilíneo.

Os efeitos do conjunto de sua obra mostram uma iluminação muito singular, remetendo-nos a um tempo no qual a base da iluminação não natural era promovida com velas, criando uma atmosfera religiosa, um rito primitivo, remetendo a ídolos mágicos. Esta criação sintética, elaborada na singular simplicidade, indica, em modo de flecha, o caminho, o vetor a ser seguido, como na Árvore Cabalista com o derramamento do conhecimento divino, descrito no livro Sefer Ietizirá, que abordamos no Capítulo 2.

As bocas diminutas nas esculturas de Modigliani explicam a supremacia do ato de ouvir sobre a fala. Sua geometria buscou a interiorização, a indicação de que o ato de ouvir é mais importante para a compreensão do que o ato de falar, indicando uma atitude contemplativa.

A pureza formal da escultura de Modigliani induz à potência na superfície, mas carrega uma imaculada delicadeza plástica que conduz à busca do semblante feminino ideal. No entanto, a escultura de Modigliani não foi bem recebida por todos. Em 1984, no centenário do nascimento de Modigliani, foi encontrada no Fosso Real, na cidade de Livorno, uma escultura que supostamente teria sido de sua autoria e que teria sido descartada por ele, em uma de suas visitas à cidade, em 1909, em função da má recepção de suas obras por parte dos críticos da época. Modigliani, incansável 
pesquisador dos múltiplos universos das artes plásticas, percebeu na estética o segredo a ser descoberto, o fascinante viver interior no qual a arte expõe o mistério.

Modigliani abasteceu suas obras com seu conteúdo de vida, de sua criação tradicional judaica, acrescido de seu conteúdo genético e depositou na representação artística esses estados superiores de consciência; superiores pelo motivo de buscarem um estado além do mundano, no qual o fato de ele não pintar os olhos de seus retratados declarava que ainda não via, não observava suas almas!

A aura, objeto de luz, de referência cabalista, esse pensar benjaminiano ${ }^{135}$, trata do fragmento teológico-político que desenvolve a ordem do profano, na busca do messiânico (SCHOLEM, 1992). Esse relacionamento teológico é de pura criação do artista, na realização da felicidade, a chegada ao Reino de $D^{\prime} u s$, que na mística judaica é o maior prêmio (BENJAMIN, 2000).

A arte de Modigliani está totalmente ligada ao simbolismo de um conteúdo formado por uma tradição que busca a compreensão do estar vivo e de sua relação com o universo.

As mais importantes festas judaicas são o Pessach e o Rosh Hashanah ${ }^{136}$. A literatura rabínica da Torá explica que o Rosh Hashanah é celebrado por ter sido o dia em que Adão e Eva foram criados e logo incorreram no erro de tomar da árvore da ciência do bem e do mal, ou seja, viram com "seus olhos" um outro mundo. Na véspera da celebração dessa festa, é realizada a ceia que remete à lembrança da vida e dos costumes, de forma totalmente simbólica. A mesa é organizada com comidas típicas, como sinal para um ano novo bom e doce (em hebraico shaná tová umetuká). Porém, segundo a mística judaica da Cabala, esses símbolos têm o poder de mudar o destino,

\footnotetext{
${ }^{135}$ Benjaminiano é um adjetivo que se refere à filosofia de Walter B. S. Benjamin (1892- 1940), ensaísta, crítico literário, tradutor, filósofo e sociólogo judeu alemão e amigo de Gershom Gerhard Scholem.

${ }^{136}$ Rosh Hashanah (em hebraico הנשה שאר, tradução cabeça do ano) é o ano novo judaico. Ocorre no primeiro dia do mês de Tishrei (setembro-outubro do calendário cristão), primeiro mês do ano no calendário judaico rabínico.
} 
por serem símbolos que fazem nosso ponto de vista mudar com relação a fatos e perspectivas. Os alimentos simbólicos são a chalá (pão) redonda, maçã com mel, romã, tâmara e o peixe. Rosh Hashanah é também o Dia do Juízo, quando D'us inscreveu o destino dos justos, dos não tão justos e dos absolutamente ímpios. Os justos são selados no Livro da Vida ${ }^{137}$; os não tão justos têm dez dias para refletir, até o Yom Kippur ${ }^{138}$, e os ímpios são eliminados do Livro da Vida.

Nas obras de Modigliani os olhos representam a existência ou não da alma. A alma, por sua vez, existe em cinco níveis ${ }^{139}$ no judaísmo. É por essa razão que a inspiração divina é chamada de ruach hakodesh, em hebraico. A inspiração de Modigliani para com os olhos adveio do Rosh Hashanah, que significa "cabeça do ano", pois os olhos estão na cabeça. Na ceia, se representa simbolicamente o estar atento para um bom olhar. É por isso que se oferece a cabeça do peixe, pois seus olhos estão sempre abertos e limpos, purificados pelas águas. A palavra hebraica para olhos é ayin, que significa ver e, por extensão, entender:

Ouve, povo insensato, que não tem coração: vós, que tendes olhos não vedes: e que tendes ouvidos, e não escutas. Jeremias 5:21 (BÍBLIA SAGRADA, 1980, p. 620).

Obceca o coração deste povo, e ensurdece-lhe os ouvidos; e fecha-lhe os olhos; para que não suceda que veja com os seus olhos, e ouça com os seus ouvidos, e entenda com o seu coração, e se converta, e eu o sare. Isaías 6:10 (BÍBLIA SAGRADA, 1980, p. 579)

\footnotetext{
${ }^{137}$ O Livro da Vida é mencionado na Bíblia como o Livro de $D^{\prime} u s$. Nele estão inscritos os nomes dos que herdarão a vida eterna.

${ }^{138}$ Yom Kipur (em hebraico יום כיפור) é o Dia do Perdão, nono dia de Tishrei (primeiro mês). É um dia especial de ênfase ao perdão e à reconciliação, segue-se um jejum completo de 24 horas.

${ }^{139}$ Os cinco níveis da alma está além do intelecto. Da ligação entre corpo e alma (um raio de luz) surge o $e u$, e ele não é constante, sendo diferente em cada estágio da vida. Assim a Cabala criou o primeiro nível: Nefesh a alma animal; o segundo Ruach a alma divina; o terceiro Neshamá a alma superior; o quarto Chayá a essência vivente e o quinta Yechidá a essência única.
} 
Ayin também representa a luz primordial, ou seja, a luz espiritual de $D^{\prime} u s$ mencionada em Gênesis 1: 3: “E disse D’us: “Seja luz!” E foi luz.” (TORÁ, 2001, p.1). Foi o que aconteceu com Adão e Eva, quando passaram a ver o mundo com outros olhos.

Modigliani tratou os olhos, em suas obras, realmente como "janelas da alma", tal como podemos observar na Figura 43. Neste desenho, a sua geometria é sobreposta pela Árvore Cabalística (ver a Figura 38); seu desenho longilíneo, existente pela questão da fluidez da luz é realizada com a estética de um artista excepcional. Ao observarmos esta figura, notamos três sefirot: 1 Kether (Coroa), 2 Chochmah (Sabedoria) e 3 Binah (Compreensão), que neste estudo criam a base de um triângulo exatamente sobre os olhos, querendo deixar claro, inteligíveis, as palavras compreensão e sabedoria e que, somente pelo conhecimento da matéria divina, a coroa, será possível ter a consciência da vida através da alma. Assim, Modigliani, ao representar os olhos pintados de várias maneiras, reconheceu a existência de alma no retratado em seus vários níveis. Quanto às outras sefirot esboçadas, devemos prestar atenção àquela que está sobre o pescoço, a sefira chamada Tiphereth (Beleza), que representa a fala, o poder do verbo, que se fez carne, que se fez matéria, o poder da oração. Unindo as quatro sefirot forma-se um quadrado no rosto, lembrando as auras nas obras do artista El Greco (1541-1614). 
Figura 43: Modigliani - "Geometria e Cabala", 1908/?, tsp, 21 x $13 \mathrm{~cm}$, caderno de desenho (detalhe)

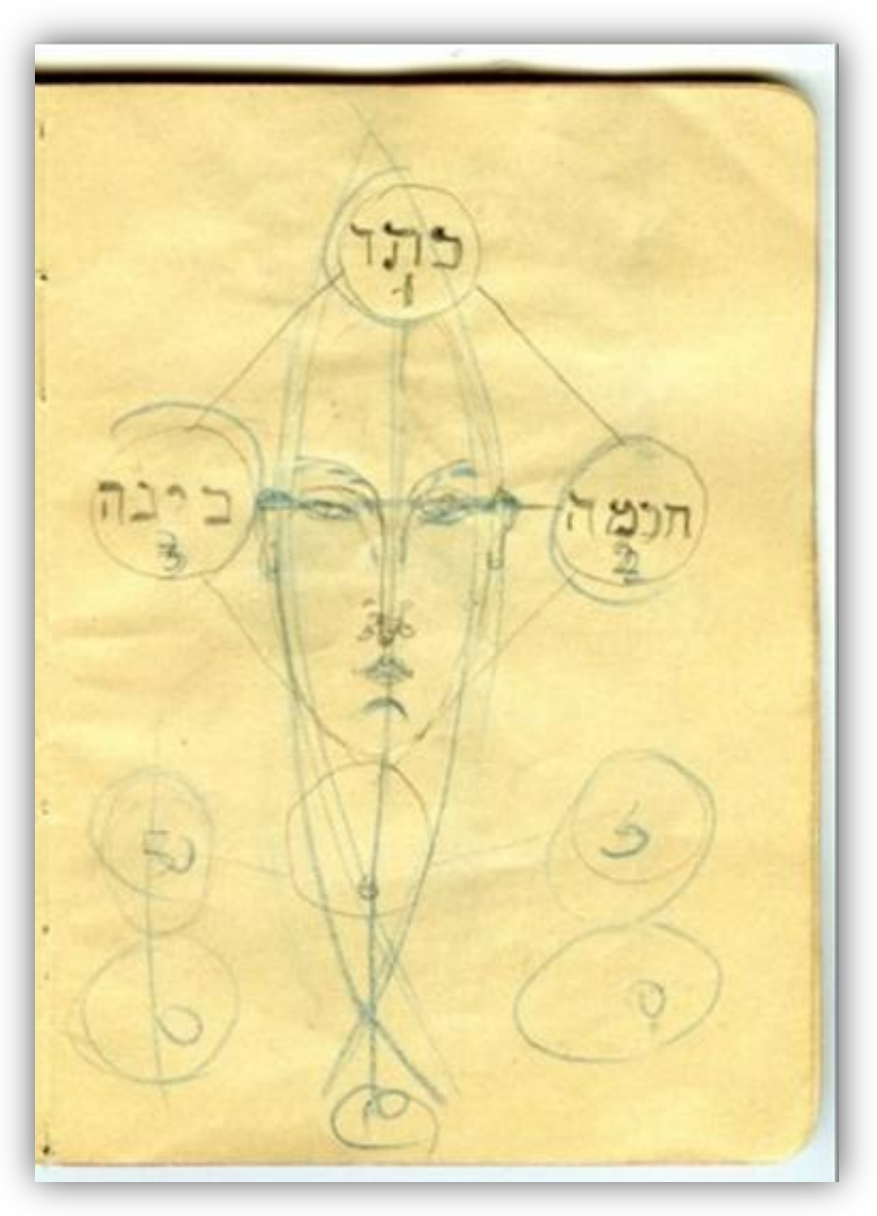

Fonte: Modigliani Institut, Roma. Foto do autor, 2017.

Na Figura 44, Modigliani retratou Leopold Zborowski, intelectual polonês que veio a Paris para dar sequência a seus estudos em Letras. Zborowski era de família abastada, conhecia muitos artistas e possuía grande apreço pela arte. Conheceu Modigliani em 1916 e, em pouco tempo, propôs ao artista o soldo de 15 francos diários mais material de pintura e modelos. Assim, a produção de Modigliani pode ser desenvolvida de modo a atingir uma fase realmente madura. 
Figura 44: Modigliani - "Leopold Zborowski", 1916/19, ost, 106 x $66 \mathrm{~cm}$, MASP

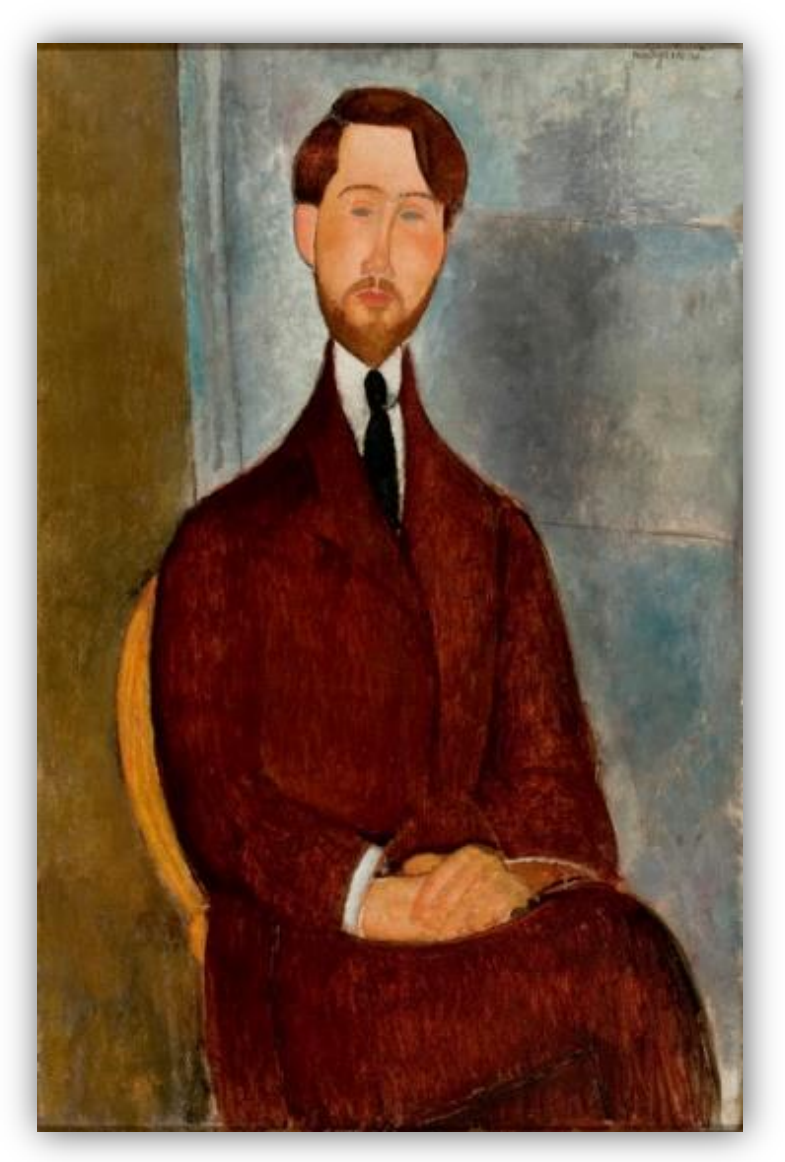

Fonte: CHATEAUBRIAND, 2008, p. 128.

Esta imagem, da Figura 44, representa Zborowski em formato longilíneo, com os ombros inclinados para baixo, formando um colo, que induz a uma ligação e finidade com o mundo superior; os olhos semicerrados, sem íris, indicam uma questão interior; a mão esquerda sobre a direta indicando o lado do sentimento (coração) sobre o da ciência. Esta análise, sob o ponto de vista cabalista, indica um estado de plenitude e postura de espírito elevado, indicando o estado de altivez do representado. A face voltada para o observador indica a configuração característica dos seres verdadeiros e mostra a decorrência da estruturação das suas partes, delineando o feitio sobre-humano, onde o estado físico sob o qual se apresenta um corpo, com uma substância de 
exuberante distinção, é apercebido precisamente pela compostura do fitar. Suas pernas cruzadas, de maneira inversa a das mãos, perna direita sobre a esquerda, indicam um momento de estabilidade corpórea, com o intuito de atestar a potência do autocontrole na compreensão da vida. A sombra sobre a parede azulada esclarece que o corpo, proprietário da matéria densa, que produz o impedimento da chegada da luz à parede, é um ser de conhecimento pronto a suas realizações. O terno marrom, uma das cores, senão a favorita, usada por Modigliani para a vestimenta (a mesma que ele usa para seu autorretrato também pintado em óleo sobre tela), representa a cor da terra, o símbolo da matéria, a realização na vida (PANOFSKY, 1979).

Como sabemos, os símbolos visam a ajudar a perceber o que é difícil de compreender. O símbolo é, portanto, muito mais amplo do que o processo simbólico ou do que a própria entidade. A Cabala teosófica considera a natureza do símbolo exatamente deste modo (IDEL, 2000, p. 302). 
Figura 45: Modigliani - "Max Jacob", 1916, ost, 73 x $60 \mathrm{~cm}$, Museu Düsseldorf

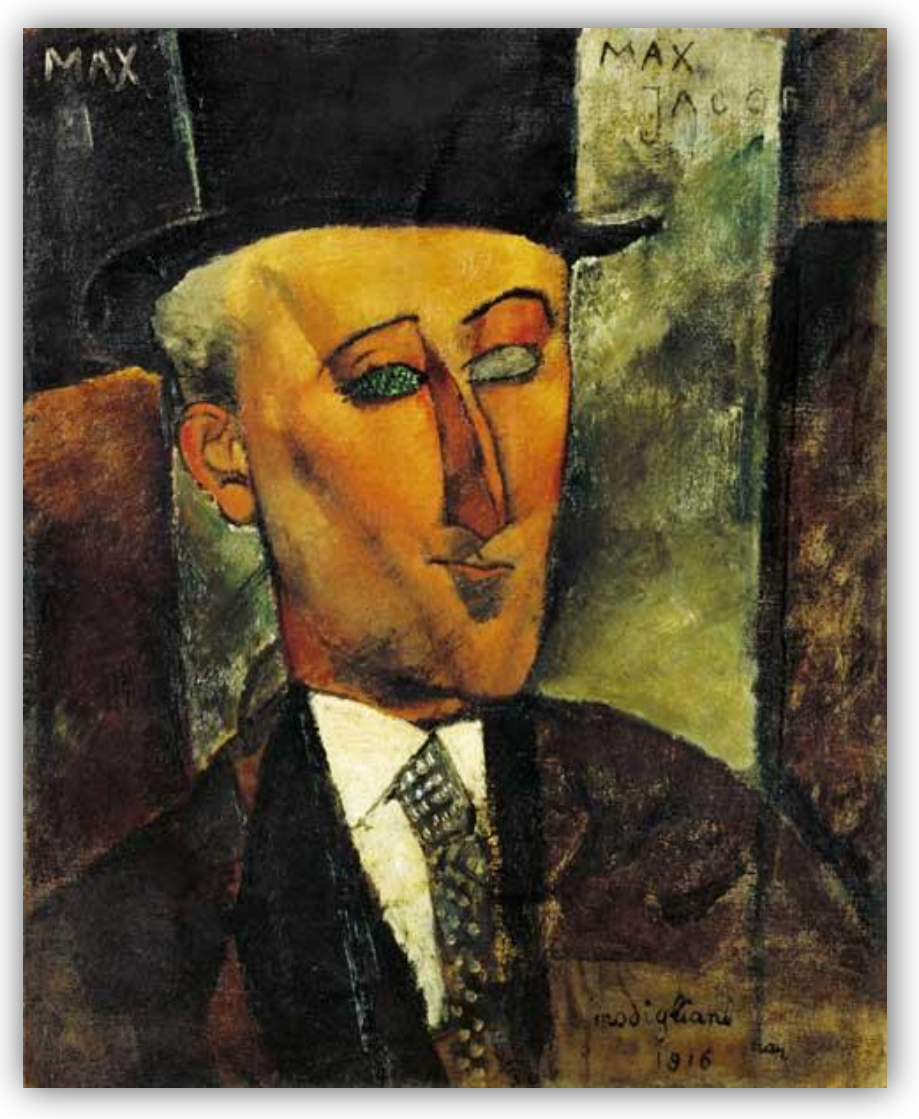

Fonte: GALLAND, 2005, p. 107.

A Figura 45 apresenta o retrato de Max Jacob, crítico de arte, pintor e poeta bretão de família judia. Jacob afirmou que nunca iria à Montparnasse, pois vivia em Montmartre, uma região mais condizente com suas posses e posição social. No entanto, acabou indo à Rive Gauche (Margem Esquerda), para que Modigliani pintasse seu retrato. Modigliani, atraído por este homem de sensibilidade, realizou o retrato com requintes, utilizando a geometrização para apresentar uma massa escultórica detida nesta obra bidimensional. A assimetria no olhar expõe um homem de buscas constantes, para quem o ato de viver é de eterno conhecimento. A obra detém vários fundos, em várias cores, apresentando uma vida de movimentos, acordos e desacordos, nítida em poetas. Trata-se de um retrato realizado como um busto alegórico tridimensional; a 
desproporção da cabeça traz à vista um estado de pensador; o rosto apresenta um triângulo apontando para baixo, que tem como significado a doação. Os olhos incompletos, mesmo rabiscados, transmitem um estado de contrastes evidentes. Privados de íris, esses olhos transmitem o vazio pronto a ser preenchido. Os olhos, novamente, nos lembram da questão anímica, uma simbologia de base cabalista que nos faz observar e verificar as mensagens deixadas por nosso artista. Os ombros inclinados entram em conflito com a cabeça enquadrada. Sua fixação com o tamanho de grandes proporções definem uma base de pintura pastosa; a cor clara da pele, com rubor evidente, transmite um estado de sentimento. O semblante direto é enaltecido pela cartola, que indica a elegância e a adesão à moda modernista parisiense. O posicionamento do retratado indica que se trata de uma pessoa eleita, como um sacerdote, um ser acometido de saberes. Os contrastes evidentes revelam, principalmente através do nariz, uma postura eficaz na relação com a vida e como as esculturas de Modigliani. As protuberâncias indicam um conjunto de qualidades e características de condições em que se encontra, em determinado momento, na construção de uma pessoa, demonstrando suas condições emocionais e psicológicas que expõem nosso artista influenciador.

Ao investigar os nus de Modigliani, percebemos que não são simples nus, mas formas pertinentes a um contexto e conduta históricos. Seus estudos em Florença e Veneza determinaram que suas fontes se apresentam em seus trabalhos que remetem às Vênus do passado, mas sua técnica é a de seu tempo: moderna. Na questão de 1909, Modigliani enfrentou seus compatriotas italianos, declinando de sua ligação com o 
movimento futurista ${ }^{140}$. Ele estava em busca de uma criação própria e bebeu de várias fontes, mas sua arte e seu estilo são pessoais (CHATELET, GROSLEIR, 1991).

A Figura 46 mostra a pintura de uma mulher nua. Modigliani a pintou enquadrada em primeiro plano, da esquerda para a direita, numa escrita sensual, numa sequência limpa de um corpo marmorizado, mas com toque de carne e calor humano com adornos exóticos, espaços próximos e aconchegantes. A tela é ocupada pela superfície feminina, sem qualquer distração, apresentando contornos sinuosos que insinuam a paixão. Modigliani complementou esta tela com cores quentes que remetem à sensualidade e à delicadeza. A escolha de Modigliani foi por uma sensibilidade augusta, pela busca do belo como referência de proporção. Não se apercebe nesta obra referências à tradição judaica, mas sim à vida boêmia do artista, sempre envolvido com seus vários amores.

\footnotetext{
${ }^{140}$ Futurista foi um movimento do início do século XX, dirigido para o futuro. Visando à destruição da arte anterior; cultuava a mudança, a velocidade, a máquina. O Manifesto do Futurismo foi escrito pelo poeta italiano Filippo Tommaso Marinetti (1876-1944), em 1909.
} 
Figura 46: Modigliani - "Nu deitado ${ }^{141 ",}, 1917$, ost, 60 x 92 cm, coleção Gianni Mattioli, Milão

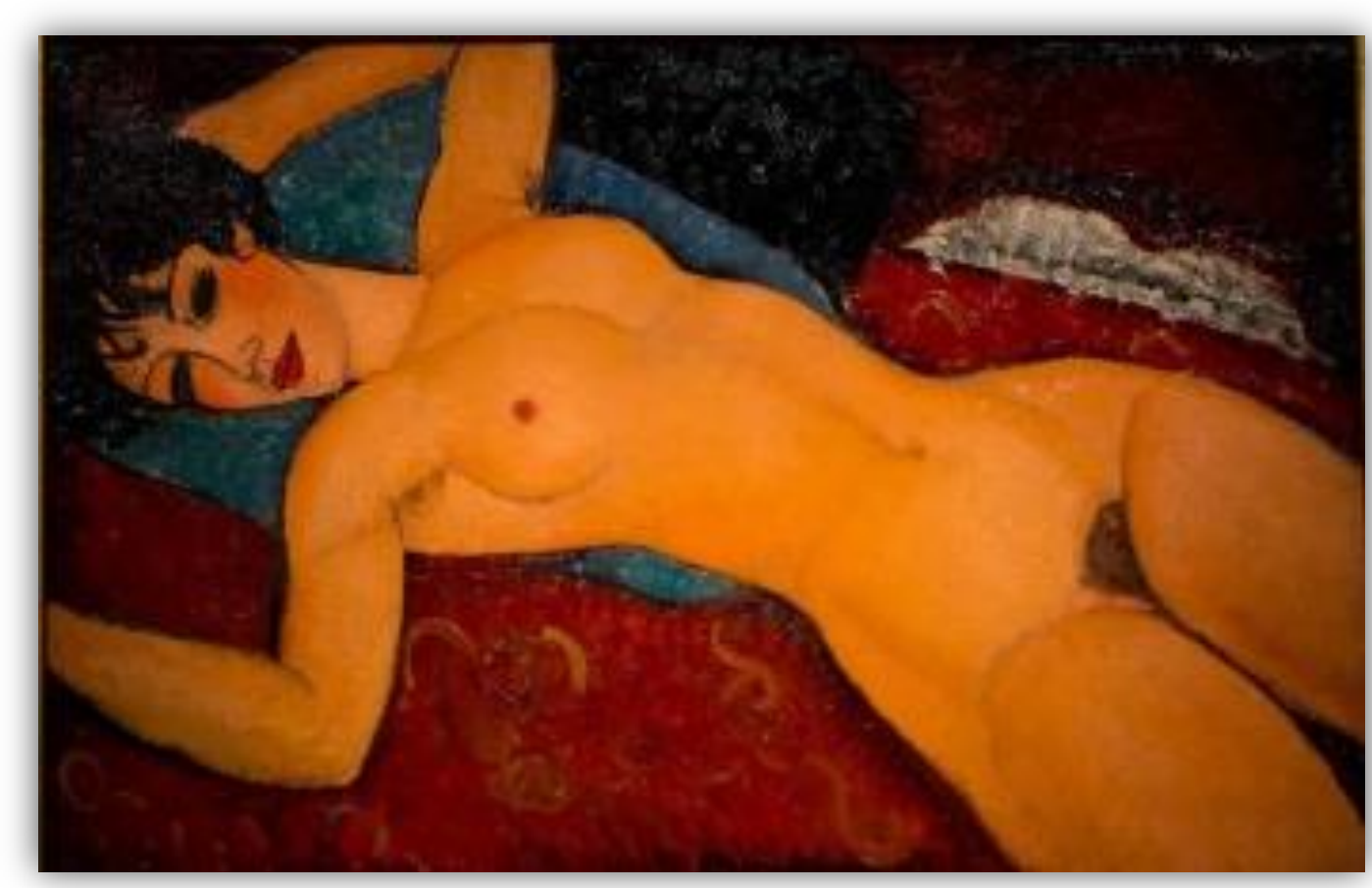

Fonte: GALLAND, 2005, p. 125.

Na exposição individual de Modigliani, em 1917, na Galeria Berthe Weil, o vernissage apresentou uma grande quantidade de nus, tocando os observadores a tal ponto pela sensualidade das obras que a polícia acabou fechando-a no mesmo dia. Modigliani com suas pinceladas refinadas, com suas cores próprias, sua polidez cultural, trouxe a essas obras um gozo de transferência estética e mística. O perturbável caráter monumental do gênero dos nus, suas curvas sinuosas, as posições dos braços abertos, os seios arredondados, as pernas ocultando o segredo do prazer criaram uma espécie de musicalidade que poderia conduzir o ouvinte à seda da pele da musa observada, à luminosidade que chegava aos olhos oferecendo um momento de convivência. Os nus de Modigliani conduzem a uma atmosfera de total liberdade de

\footnotetext{
${ }^{141}$ A obra Nu couché (Nu deitado), de Modigliani, foi vendida em 2015, na Casa de leilões Christie's de Nova Iorque, por US\$170,4 milhões de dólares. Adquirido pelo investidor chinês Liu Yiqian.
} 
interpretação e sentimentos que só poderia ser conseguida por um artista que conhecesse muito bem os seus próprios mistérios.

Jeanne Hébuterne foi retratada por Modigliani em mais de 25 obras que deixam transparecer seu espelhamento anímico, expresso na combinação secreta do pensar das operações criativas de seu amor, que marcam um sentimento profundo, refletindo o esotérico de sua comunicação divina. Um destes retratos foi realizado em 1918 (Figura, 47). Trata-se de uma pintura intimista, com a cabeça representada levemente inclinada para baixo para observar, para fitar com profundidade algo a ser pensado, refletindo e demonstrando certa inquisição ao espectador. A conformação no estilo de Modigliani nos deixa perceber um rosto afilado com seu típico pescoço longilíneo, representando um apontamento reflexivo sobre Jeanne, o amor de sua vida. O olhar penetrante absorve o ser vidente; o rosto longilíneo traduz-se na elevação clara, no formato nasal. Os cabelos funcionam como uma moldura, uma aura protetora, criando com a cor e a forma um movimento estático, uma condição antagônica que expõe, assim, um estado purificador. Modigliani, com o uso de cores vibrantes, mas com transparência, obtém, com pinceladas cursivas, formas fluidas com traço sutil e de leitura sublinear, trazendo um conteúdo oculto, o segredo de seu amor. Jeanne, sentada, nos dá a base para uma não atitude, onde sua projeção torna-se profunda, pois a forma nos conduz a um estado de contemplação. As percepções são de um momento pleno, de pensamento introspectivo, de pura observação, quando o interno remete ao externo, criando assim um movimento mental/espiritual. $\mathrm{O}$ pescoço alongado remete às tradições judaicas já anteriormente mencionadas neste trabalho. 
Figura 47: Modigliani - "Jeanne Hébuterne", 1918, ost, 46 x 29 cm, coleção particular, Berna, Suiça

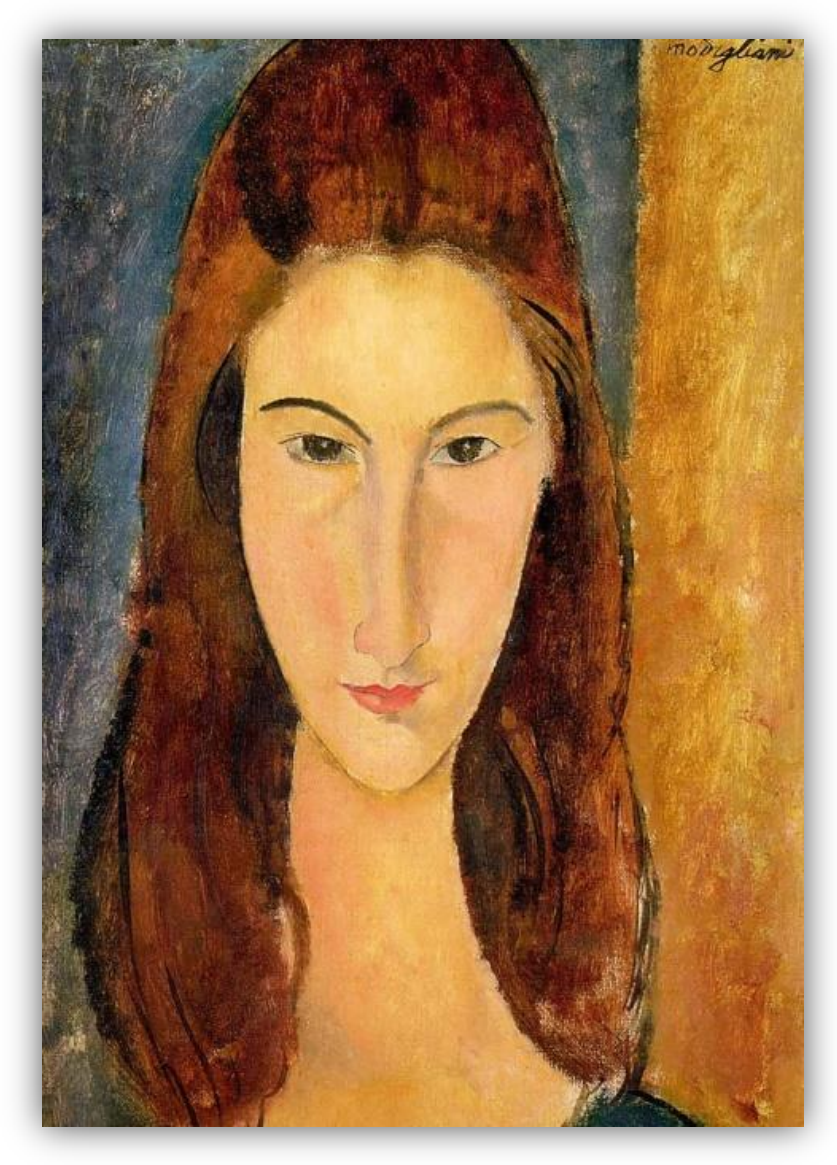

Fonte: NICOSIA, 2011, p. 115.

Esta obra (Figura 47) advém de uma série de três, realizadas em 1918, e assinadas por Modigliani. A extensão dos traços alongados finaliza a transição de um olhar de certa forma perturbador. Neste caso, a existência da íris nos penetra, transmitindo um ar angelical, talvez de um arcanjo, "mensageiro de D'us", pois os olhos de Jeanne são intensamente azuis, transmitindo a ligação com o céu, fonte de iluminação, fonte do conhecimento que o avô de Modigliani lhe apresentou (MARÍN, 1984). 
Figura 48: Modigliani - "J. Hébuterne", 1918 , ost, 100 x 65 cm, coleção particular, Paris

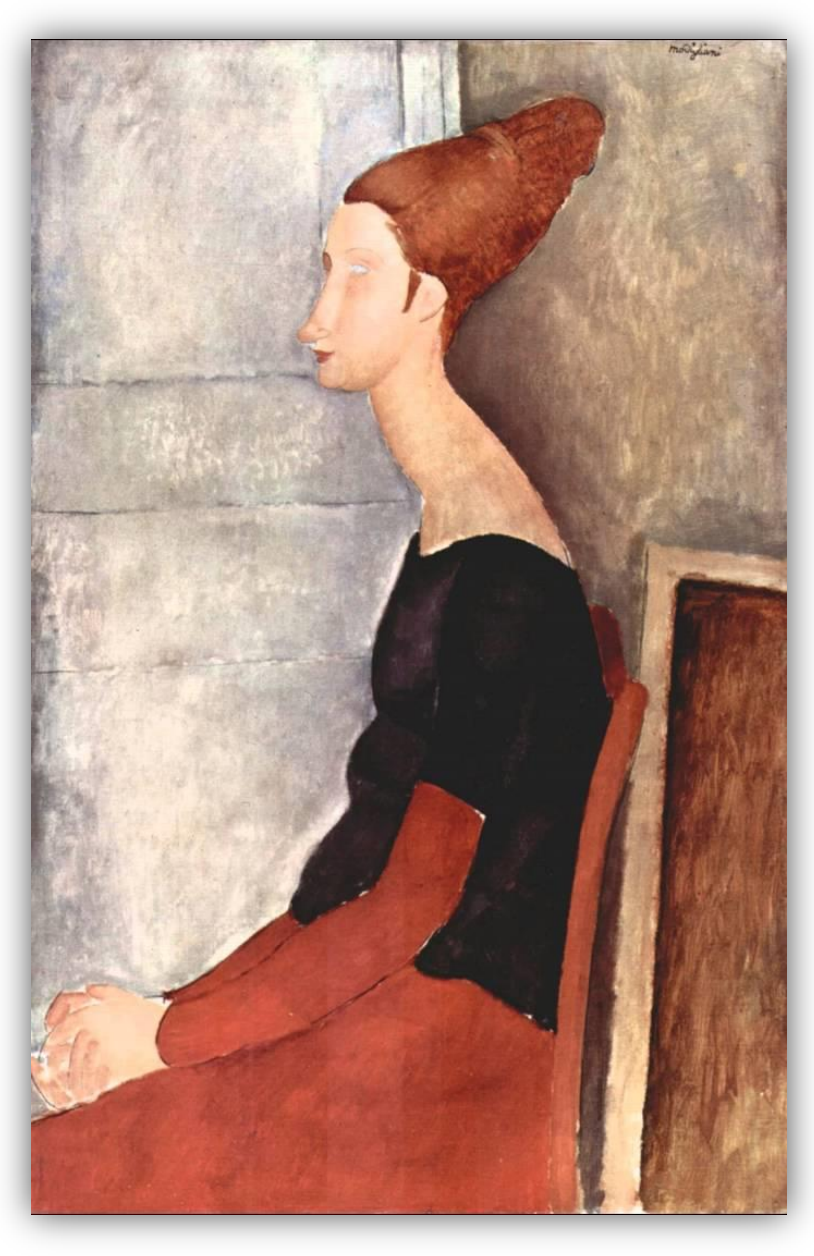

Fonte: GALLAND, 2005, p. 148.

A Figura 48 apresenta outro retrato de Jeanne Hébuterne. Faz parte do conjunto de retratos realizados por Modigliani sobre sua companheira, na Côte d'Azur, em 1918. A obra realizada de perfil, exceção em seus retratos, apresenta Jeanne com um penteado particular, em forma de cone, indicando certo estilo elegante e sublime em suas proporções. Ela é representada com os ombros soltos, criando nitidamente uma forma longilínea e sinuosa, em formato de 'S'. Este trabalho, com poucos contornos em preto, possui uma grande coloração. A paleta é plena, carregada de cores intensas. A grande chave dessa obra é a protuberância em seu ventre, sutil, mas revelando seu estado especial, a gravidez. Ao pintar sua companheira grávida, Modigliani indica seu estado 
de realeza, no qual o penteado representa uma espécie de mitra, simbolizando o endeusamento, ou melhor, o receber, relembrando, assim, o significado da palavra Cabala. O ventre, que carrega a criança, está exposto no tom vermelho/ocre, cor da terra, cor da matéria (UNTERMAN, 1992). Jeanne somente mostra o pescoço e pequenas partes dos ombros. A paleta detém uma gama de cores que suaviza e torna denso o olhar; o olho não tem íris, pois simboliza a criança que está por vir; as pinceladas pastosas no rosto criam um ar de mármore, que ultrapassa o tempo. Nessa obra, Modigliani apropria-se da obra de Botticelli ${ }^{142}$ intitulada "Retrato de uma jovem", que se apresenta com uma postura que se refere ao passado para apresentar uma iconografia que remete à tradição. A relatividade do fundo diante das cores dá um movimento estático de paralelismo e projeções potentes na artificialidade da arte bidimensional. Modigliani instala por vezes, portas, colunas, cadeiras, chassis, molduras de quadros, dando um aspecto de vida e apresentando uma corrente do tempo com a mudança, ainda não completamente revelada, entrelaçando e justificando os demais itens representados. A representação imagética de Modigliani é promovida de um conhecimento esotérico profundo.

Em 1919, Modigliani executou o retrato de Lunia Czechowska (Figura 49). Ele era escolhido para retratar, mas também ele escolhia quem queria retratar. Lunia Czechowska era amiga do casal Léopold e Hanka Zborowski que faziam parte do grupo de amigos de Modigliani. Ela era uma mulher culta, madura e detentora de uma beleza singular. Modigliani retratou-a em mais de dez pinturas. $\mathrm{O}$ motivo de não ter pintado seus olhos esconde um segredo: a tradição não é plena. A existência por mais sábia que seja nunca será completa; assim, a incompletude é o que nos faz viver! Nessa obra, uma simples blusa sobre os ombros demonstra a pincelada como uma verdadeira assinatura

\footnotetext{
${ }^{142}$ Alessandro di Mariano di Vanni Filipepi ou Sandro Botticelli (1445-1510) foi um pintor italiano, aprendiz no ateliê de Filippo Lippi (1406-1469). Ele estudou na Escola Florentina do Renascimento.
} 
ao dar liberdade ao longo pescoço que, transmite traços vertiginosos, assim afiados, para deixar parte do colo descoberto, criando um 'desvolume' que elabora um cuidar gestual, deixando a obra solta. De mística elegância, essa obra pode se identificar com a bela que caminha: Nefertiti ${ }^{143}$. A obra apresenta, também, uma contextualização atemporal, uma musicalidade dedicada ao silêncio, com um olhar não natural, um aspecto que fere sentimentos profundos.

Figura 49: Modigliani - "Lunia Czechowska", 1919, ost, 46 x 33 cm, coleção particular

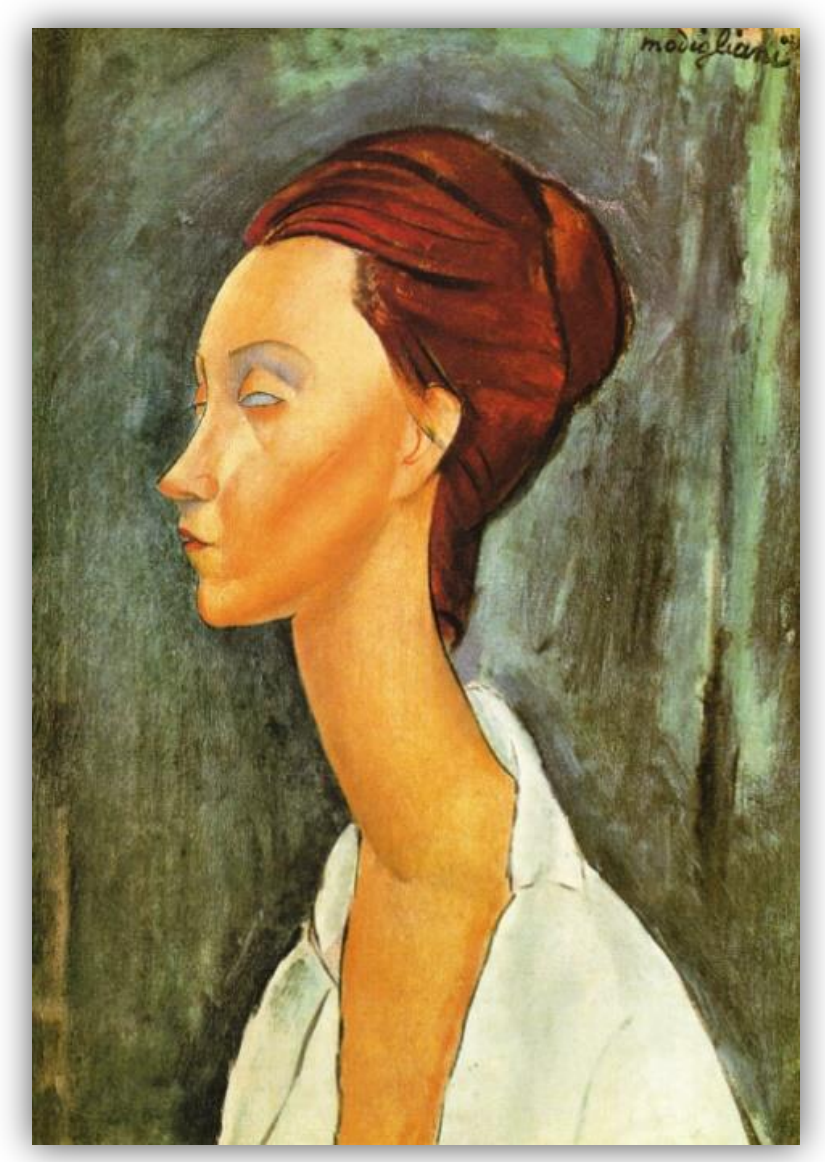

Fonte: GALLAND, 2005, p. 171.

\footnotetext{
${ }^{143}$ Nefertiti (13??-1331 a. C.) foi rainha da XVIII Dinastia do Egito antigo, esposa do faraó Amenófis IV, conhecido como Akenáton (13??-1336 a. C.). Nefertiti e Akenáton tornaram-se conhecidos com a revolução religiosa pois, reverenciavam apenas um deus: Áton, o disco solar (ver Figura: 25).
} 
Nesta obra (Figura 49), está presente um estado de profundo reconhecimento iniciatório. Esta mulher retratada em pleno momento contemplativo exemplifica os ensinamentos dos místicos cabalistas do século XIII que defendiam que o exercício para se chegar a $D^{\prime} u s$ era através do choro. Assim, aos adeptos, que conhecem os segredos do oculto, o mistério enigmático e inexplicável da vida, esse estado obscuro, esse escrutar que tem sua origem na fonte da luz, apresenta-se na clareza da retina e ilumina o estado impenetrável e incompreensível do não desvendado, sendo que o desconhecido, o inaplicado existe no fenômeno, na luz. Essa obra expõe, fechada em si mesma, uma diáfana beleza da descoberta do caminho divino.

Buscando esse entendimento sobre o autoconhecimento e a relação cabalística com a obra de Modigliani, realizamos uma análise dos três autorretratos do artista apresentados a seguir.

A Figura 50 apresenta um óleo sobre cartão, datado de 1915. Trata-se de um autorretrato de Modigliani representado como Pierrot, indicando o simbolismo do mistério, dos sonhos e ilusões, referindo-se à grande divindade regente na magia (ROOB, 2001) e também à personificação que detém todo conhecimento e registros. Representa o passado, o presente e o futuro. Esse personagem sentimental e, por vezes ingênuo, criado pela comédia italiana/grega foi transportado para o teatro francês, tendo se fixado na pantomima ${ }^{144}$. Com seus trajes largos e enfeitados no período da Renascença, o Pierrot às vezes é confundido com a figura do palhaço, no entanto, tem outro significado.

Aristóteles (384-322 a. C. Grécia), filósofo grego, em sua "Arte Poética", diferenciava a tragédia da comédia, explicando que a tragédia trata de homens superiores e a comédia, dos inferiores, das pessoas comuns. A importância da comédia

\footnotetext{
144 A Pantomima, surgida na Roma antiga, envolve representações dramáticas, narrativa por gestos, expressões faciais e movimentos.
} 
mostra a possibilidade da democracia, que se inicia na política. Assim, o Pierrot indica que ninguém está a salvo de críticas. A comédia é necessária para o reconhecimento do valor humano, no qual o ser mitológico fica maior que o momento ameaçador. Portanto, o rir desfaz os laços dos grilhões dos poderosos.

Figura 50: Modigliani - "Autorretrato", 1915, osc, 43 x 27 cm, SMK Denmark

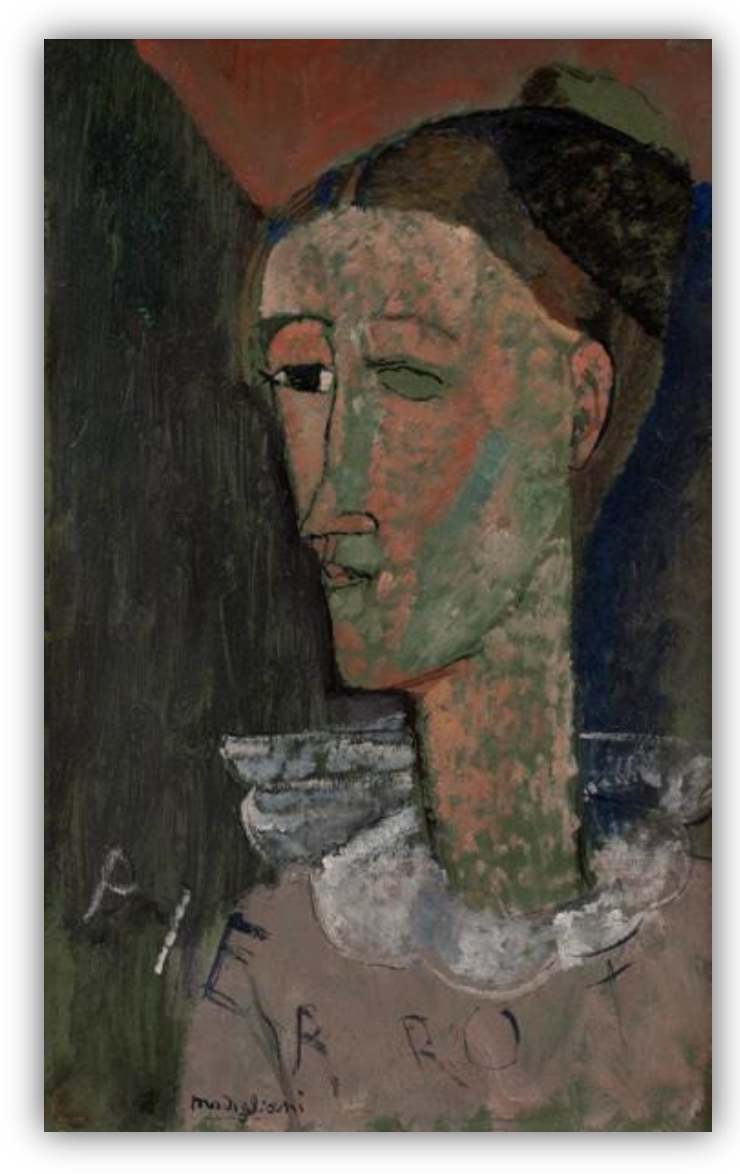

Fonte: PARISOT, 2010, p. 200.

Na obra supracitada (Figura 50), Modigliani retratou a si próprio no anseio da representação da relação com o mundo, indicando que se o ser vivente não compreender sua existência e suas necessidades, sua compreensão será de uma vida alegórica, sem realização do seu ser real. O olhar retratado nessa obra é indireto, pois é lugar de pertencimento do outro. Trata-se de uma obra simples que pede ao observador um 
momento de projeção, um momento de captação, para saber seu próprio tamanho em relação ao meio em que vive, refletindo, assim, a experiência tratada no livro Sefer haBahir (Livro da Iluminação), mencionado no Capítulo 2. Seu pescoço longilíneo indica um ser iniciado na compreensão de si; seus olhos, o da esquerda podendo observar a vida, e o da direita, sem a íris, demonstrando a incapacidade de ver a realidade.

O segundo autorretrato de Modigliani, representado na Figura 51, é um desenho realizado numa época em que o retrato já estava em declínio em função da propagação das máquinas fotográficas que vieram a substituir este tipo de pintura. Nele, o rosto é objetivamente o mesmo de suas esculturas, mas sua vestimenta é quase que religiosa, é simples, até demais, não somente por ser um desenho, mas porque ele poderia recorrer a uma lapela, como era usual em seus trajes. Ele se auto representa com barba, símbolo de força e de sabedoria no judaísmo. A barba remete a um ser cerimonial, sagrado, como o Rabino, ou Rabi (רִִִִּ, em hebraico), que significa mestre, aquele que transmite com grande distinção o conhecimento; que é responsável pelo ensino e pela aplicação dos saberes do judaísmo e que, através da oração, realiza a ligação com o divino. Modigliani se retratou com rosto frontal, com cortes diretos, fitando o observador. Nesse esboço, encontramos também o desenho de uma cariátide de cabeça para baixo. Pode ter sido algo aleatório, mas no momento em que esse desenho foi executado, Modigliani já sentia seu corpo enfraquecido podendo, então, estar apontando as dores de uma cariátide, numa interpretação representativa simbólica. Acreditamos que esse desenho apresente uma representação mística, reflexiva, sobre seu íntimo, suas experiências, seus pensamentos e sentimentos vividos. 
Figura 51: Modigliani - "Autorretrato com barba", 1918, lsp, coleção Alexandre, Paris

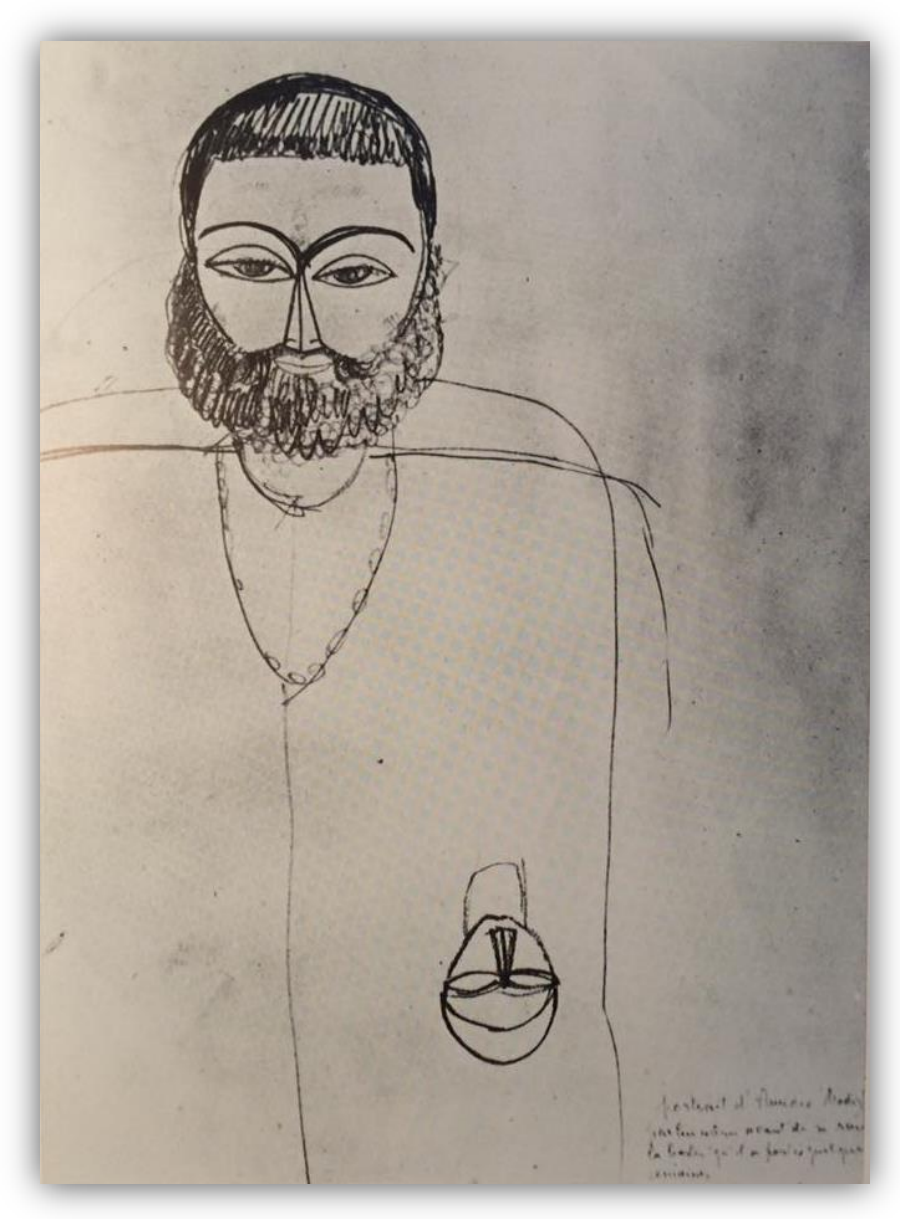

Fonte: MODIGLIANI, 1984, p. 133.

O terceiro autorretrato (Figura 52) foi realizado no final de 1919, quando Modigliani, pressagiando sua morte, decidiu se autorretratar. É, possivelmente, sua obra mais importante e está no acervo do Museu de Arte Contemporânea da Universidade de São Paulo (MAC/USP). Segundo Magalhães: 
Em seu caderno de viagem a Davos, na Suíça, em junho de 1947, Yolanda fez as anotações das aquisições do casal entre 1946 e 1947, entre as quais se encontra o "Autoritratto" (1919, óleo/tela) de Amedeo Modigliani. À página 10 do caderno, Yolanda anota: "Modigliani comprado Milão/Ganhei presente aniversário". De fato, a célebre obra de Modigliani não aparece no primeiro documento localizado de inventariamento do acervo do antigo MAM, e nas publicações sobre o artista ao longo da década de 1950, aparece como pertencente à coleção de Francisco Sobrinho Matarazzo em São Paulo. Portanto, essa obra só viria a ser institucionalizada quando da transferência do acervo do antigo MAM para a USP (MAGALHÃES, 2014, p. 25).

Figura 52: Modigliani - "Autorretrato", 1919 , ost, 100 x 64,5 cm, MAC/USP

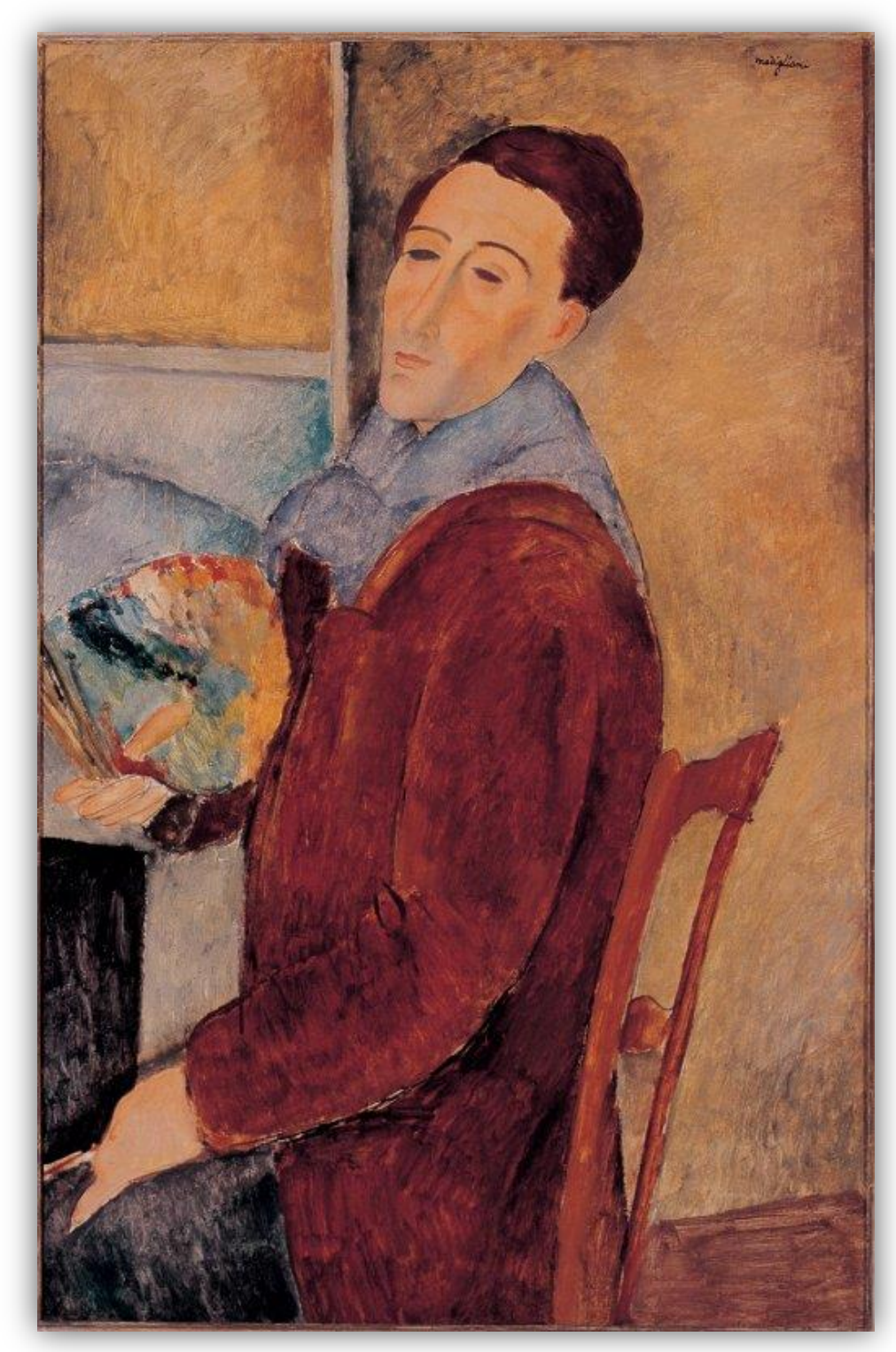

Fonte: MAE, 1990, p. 193. 
Modigliani é um ser de vocação, dotado de habilidades especiais, de apelo ou de inclinação para o sacerdócio. Sua vida foi de extrema busca de criação espontânea e original. Ele dedicou sua vida a retratar a figura humana, analisando os retratados e simultaneamente se autoanalisando. Sua última pintura apresenta-se com paleta de pintura, evidenciando o quanto seu "ser artista" foi pleno em sua vida. Como judeu, seu estado é reticente quanto ao se apresentar, ou melhor, se representar. Nesta sua última obra, Modigliani trouxe uma figura humana de clara introspecção, ambientada em seu atelier, em seu trabalho, onde os instrumentos estão presentes. Ele se retratou de perfil, com a cabeça reclinada, mostrando o espelhamento. Sua figura está presente em tons quentes e envolventes. Ao segurar a paleta com a mão direita, mostra que sua escrita, suas obras, declaravam a verdade e representam mensagens de um iniciado na arte dos símbolos. No fundo dessa pintura, no último plano, a parede é limpa, sem detalhes que obliterariam a visão do observador, a visão da mensagem do artista. $\mathrm{O}$ ambiente no qual Modigliani se autorretrata é óbvio. Ele se encontra só. Pressupõe-se um cavalete à sua frente, como base para sua escrita. Seu ato tem como objetivo apresentar um observador de conteúdos e reflexões, representando seus próprios estados mentais, sua tomada de consciência, destacando as imagens, as intenções, as emoções e suas associações.

Os olhos pintados por Modigliani neste autorretrato são totalmente negros, indicando sua profunda introspecção e que, ao chegar o momento de transição - da morte -, deverá ocorrer uma passagem de forma lúcida. Como um judeu místico, com compreensão cabalista, Modigliani acredita na reencarnação da alma (guilgul neshamot, em hebraico) e, tendo este conhecimento, em sua obra celebra a ressurreição. A obra indica, também, que o ser humano que aprendeu deve passar seu conhecimento aos demais (KAPLAN, 2002). A simbologia deste autorretrato também remete a Adão (Adam, do hebraico: barro, vermelho), o primeiro homem, representado pelo 
vermelho/marrom, de barro, a cor mais vista, inclusive, nas vestimentas dos retratados. Seu corpo está verticalmente alongado, apoiado no espaldar da cadeira. Sua vestimenta é tradicional: um longo paletó de veludo cotelê marrom representando um traje apropriado ao culto, com um cachecol azul, que apresenta um gracioso nó que o sustenta, representando o pescoço protegido, a guarda da fala, o som do verbo interiorizado.

Como podemos observar nas fotografias de Modigliani, seu cabelo é penteado para o lado, no entanto, nesse autorretrato (Figura 52) está em um formato diferente, está usando um protetor, uma quipá ${ }^{145}$, que no caso pode ser visto como receptor de uma coroa, kether, representando sua ligação com o divino, ou seja, indo de encontro ao criador, em analogia à sua assinatura no canto superior direito do observador. Modigliani se auto representa numa postura estética e plástica que alude a uma conjuntura de consciência plena, deixando assim uma mensagem de capacidade constituinte de momento perfeito para com sua integridade na busca do absoluto como artista e como ser humano.

A ambientação desta obra induz a um momento solidário ao personagem, a ele próprio. Como na maioria de suas obras, Modigliani pinta o indivíduo, o indivisível, o ser humano na busca de si mesmo. Ele pinta o personagem e absorve o conjunto dos aspectos psíquicos que fazem a unidade; no semblante relaciona os valores, as características particulares e sua ligação com a sociedade. Este é um dos marcos de seu trabalho.

$\mathrm{Na}$ Figura 53, temos informações que comprovam nossa leitura cabalística nos retratos de Modigliani. Nesse sentido, lemos, na metade esquerda de quem observa, a palavra Kether, escrita de cima para baixo, significa Coroa. Por estar escrita de cima

\footnotetext{
${ }^{145}$ Quipá em hebraico הפיכ, kipá, significa cobertura, peça de vestuário utilizada pelos judeus como símbolo da religião de reconhecimento perante o Criador.
} 
para baixo, representa a descida da iluminação do Divino. Modigliani indica a ligação com $D^{\prime} u s$, como é claramente dito em seu primeiro nome: Amedeo, amado por $D^{\prime} u s$. Na Árvore Cabalista essa sefira kether é a ligação do mundo com a divindade. Podemos observar também a escrita do número 1 (um) em hebraico דחא, que se pronuncia echád. Este número é o único que multiplicado por ele mesmo resulta nele mesmo, simbolizando o número divino que está escrito dentro do desenho de uma coroa. Observamos também as palavras Aleph e Beth, escritas por extenso, que são as duas primeiras letras do alfabeto hebraico, que representam os números um (1) e dois (2), como estão escritos por Modigliani em seu caderno de desenho, simbolizando a sequência da vida.

Figura 53: Modigliani - "Cabala Kether", 1908/?, 1sp, 21 x 13 cm, caderno de desenho

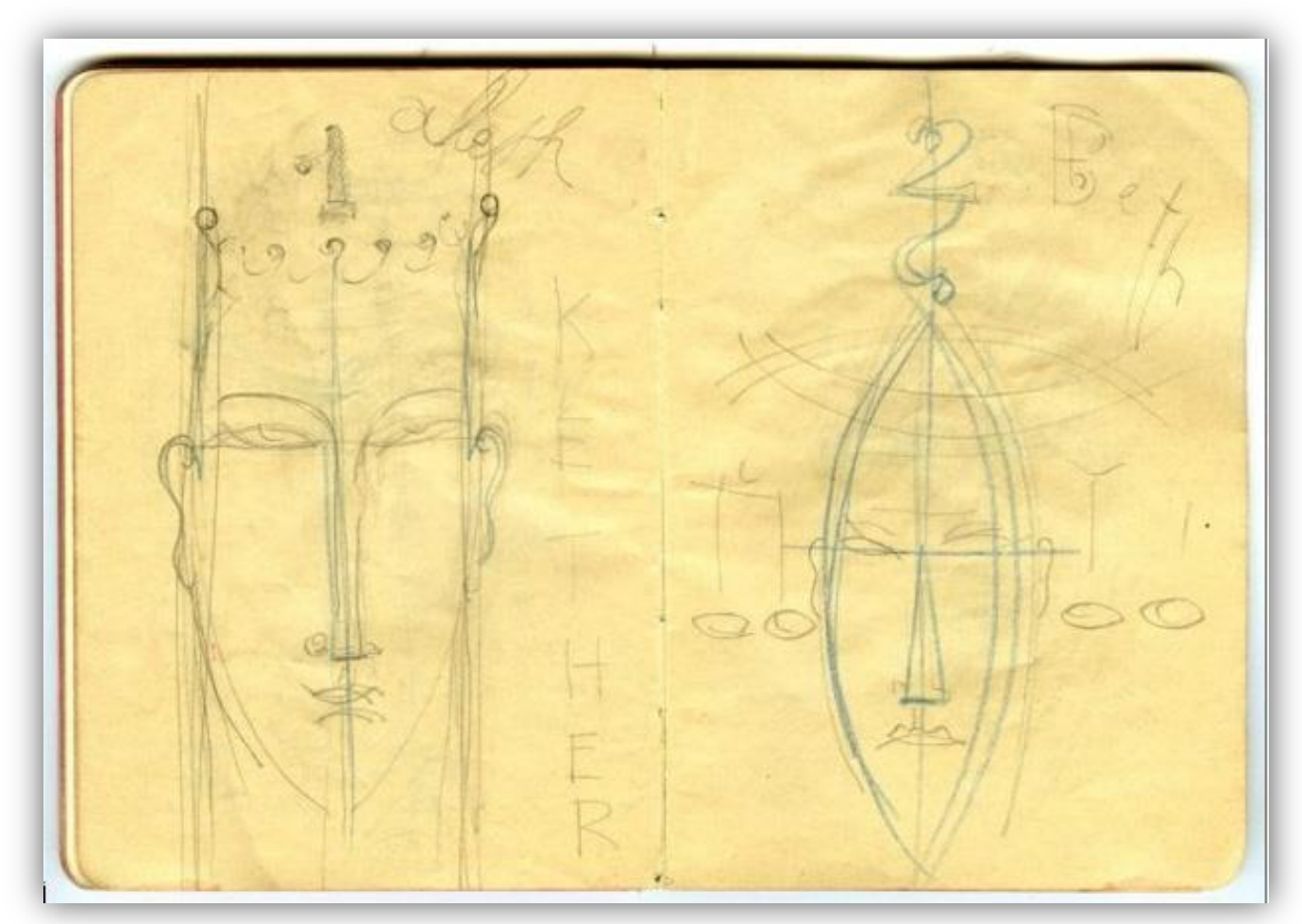

Fonte: Modigliani Institut, Roma. Foto do autor, 2017. 
A máscara mortuária de Modigliani (Figura 54) foi realizada no dia seguinte à sua morte, em 24 de fevereiro de 1920, pelo amigo e artista Moïse Kisling e pelo astrólogo Conrad Moricand. Kisling conhecia as técnicas para utilizar o gesso e Moricand o assessorou naqueles escassos minutos da madrugada no hospital HôtelDieu, conseguido pelo escritor Blaise Cendrars. As autoridades esperavam poder desembaraçar o corpo rapidamente, pois havia uma multidão de pintores, modelos, escritores, atores e bailarinas transitando pelos corredores do hospital, o que não era considerado apropriado para o local. Desse modo, o gesso foi realizado rapidamente, ficando mal feito e se rompendo em vários pedaços pouco depois de ter sido retirado do rosto de Modigliani. O escultor Jacques Lipchitz, amigo de Modigliani, assumiu a responsabilidade de reconstruir o gesso, já que Kisling havia caído em desespero considerando que sua falta de jeito foi uma espécie de traição ao amigo morto. Foi necessário fazer uma nova máscara, que foi realizada por Lipchitz.

Figura 54: J. Lipchtz - "Máscara mortuária Modigliani”, 1920, gesso, 22,2 x 15,1 x 11,5 cm, coleção Chester Dala

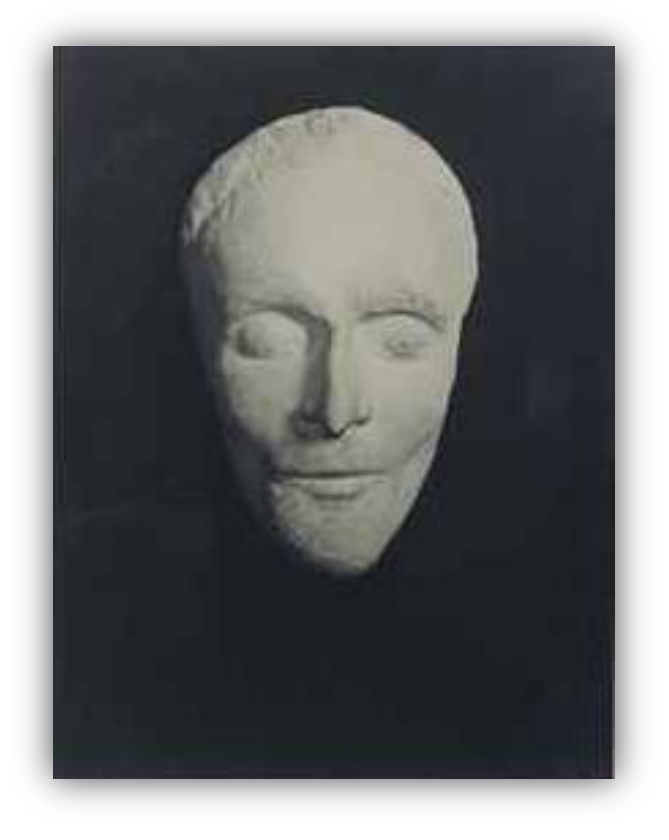

Fonte: GALLAND, 2005, p. 101. 
CONSIDERAÇÕES FINAIS 


\section{CONSIDERAÇÕES FINAIS}

Procuramos neste trabalho compreender um pouco mais sobre a vida e a obra do artista Amedeo Clemente Modigliani.

No Capitulo 1 - Modigliani: A Vida, buscamos compreender a experiência vivida pelo artista em família, na cidade de Livorno, onde, por problemas de saúde, ele recebeu sua educação no seio familiar: o carinho e o aprendizado de idiomas, com sua mãe; e o conhecimento profundo da arte e principalmente o conteúdo místico judaico, com seu avô, que fez às vezes o papel de seu pai, já que este trabalhava fora de Livorno. Descrevemos seu envolvimento com a arte e suas relações sociais a partir de sua base familiar sefardita, seus estudos dos movimentos artístico na Itália, sua morada e suas obras na França, onde viveu e criou seu próprio estilo e encontrou o amor de sua vida.

Sua família judaica tradicional, abastada e de profunda cultura, permitiu-lhe uma formação típica judaica. No âmbito da Arte, ele estudou e praticou desde os estilos renascentistas até o macchiaioli e a arte contemporânea na Itália. Tinha tendência a ser escultor, porém, pela saúde fragilizada dedicou-se principalmente à pintura. Em vida, foi reconhecido como um grande artista, mas não alcançou uma situação financeira condizente.

Modigliani foi criado de forma tradicional, como um judeu sefardita, porém, em Paris, tornou-se um boêmio, um "não exemplo". Com a união de características discrepantes, viveu a desigualdade, as discordâncias e criou a capacidade de produzir e compreender uma vida com imensos prazeres, aqueles perdidos na infância. Revelou, especialmente em seus nus, sua vida boêmia e desregrada, cercada por mulheres e relações pouco duradouras.

Em questões interiores, absorveu a tradição da mística judaica da Cabala e, mesmo não sendo um religioso ortodoxo, soube passar este universo místico para suas 
obras impregnando-as de símbolos para além das convenções e se revelando um homem pleno de inteligência e de poder criativo como poucos na história da humanidade.

Apresentamos Modigliani sempre envolvido com grandes artistas/amigos e mulheres que serviram de referência no cenário de sua vida. Entendendo, então, que a obra e suas relações fazem parte de um mesmo contexto. Nosso artista recebeu conhecimento sobre a História da Arte com uma profundidade excepcional, que se manifestam nas formas e conteúdos estéticos que poucos artistas de seu tempo tiveram a possibilidade de descortinar. Em suas viagens pela Itália, Modigliani buscou a sabedoria e apreendeu toda a tradição artística possível, mas sua sede de conhecimento era profunda, o que o fez buscar o que havia de mais novo na França, especificamente em Paris, onde acompanhou experiências inovadoras que o conduziram a um movimento criativo pessoal, no qual suas expressões plásticas transmitiram vivências de um passado remoto e, simultaneamente, a arte desse novo momento, o Modernismo.

No Capítulo 2 - A Tradição Judaico-Cabalista, abordamos a história da mística judaica, a Cabala. Pesquisamos o conteúdo profundo deste conhecimento e apresentamos as principais obras que dão alicerce a este saber. Modigliani, artista que bebeu da fonte original da tradição judaica sefardita e foi profundamente alimentado por suas experiências e pelas contribuições familiares. Ele recebeu o conteúdo místico da Cabala e o transplantou para sua arte, de maneira sutil, quase imperceptível, mas com segurança e vigor que o distinguem de qualquer outro artista de seu tempo.

No Capítulo 3 - A Mística Judaica na Obra de Modigliani, tratamos desta questão buscando interpretar as suas obras a partir de uma visão plena de significados simbólicos, segundo o conhecimento da mística judaica. Buscamos analisar suas obras discorrendo sobre a técnica, os temas e, sobretudo, sobre as possíveis relações com o conhecimento judaico-cabalista. 
Modigliani foi um ser que carregou consigo o mundo, o que o tornou testemunha de seu tempo. No entanto, ele ultrapassou seu tempo com suas esculturas e pinturas que o levaram a ser o segundo artista plástico cujas obras atingiram os valores mais elevados do mundo, devido à sua capacidade de produzir arte com um estilo próprio, como um vidente que captou sentimentos e possibilidades que vão além do que nós outros seres humanos conseguimos expressar em nosso viver.

Modigliani, em seus três autorretratos, apresentou seus vários conteúdos. Como pierrot, rabino e pintor, mostrou-nos um ser em evolução, em processo de desenvolvimento, que buscou na vida o viver, um viver puro e realizado, com experiências mundanas reais e com plenitude de felicidade, sempre em processo de transformação.

Em seu berço viveu a espiritualidade, mas, ao se mostrar como pierrot, trouxenos um ser de qualidade com um estado de consciência plena, contra as regras estabelecidas, a satisfação e contentamento de um bon-vivant, um verdadeiro boêmio, um espírito rebelde. Seu proceder vingou através dos possíveis e impossíveis estados de obtenção de si próprio.

Em seu segundo autorretrato, Modigliani representou-se como rabino, um ser austero e comedido, potente em seu saber e que detinha um conhecimento profundo da existência, alicerçado pela tradição familiar e pelo carinho do avô Isacco. Ele nos transmite um estado de crença na ação ou na influência dos poderes supranormais do conjunto das artes, das ciências ocultas, da magia da arte, na qual descreve através de seus dons o estado interior em que viveu; a totalidade e integridade consigo mesmo, a ponto de sentir que sua tradição, seu veio familiar de profundo conhecimento, a fonte de sabedoria de seu avô, o carinho de sua mãe, deram-lhe uma força ultra-humana para viver além de suas fraquezas físicas. Munido deste conhecimento, com sua vontade de 
viver, criou uma arte que apresenta um ser humano especial, que amou suas mulheres, seus amigos e, assim, amou também a sua arte.

Sua obra-prima, não simplesmente pela plástica, pois Modigliani detém outros trabalhos realmente magníficos, mas pela pintura e autoconhecimento, por ser sua última obra e seu último autorretrato foi o Pintor. Modigliani foi um artista maldito, com temperamento supostamente desregrado, carismático, de prodigiosa memória, de beleza física e presença brilhante e que se expressava com versos de Dante Alighieri ${ }^{146}$, Isidore Ducasse ${ }^{147}$, entre outros. Seu trabalho compreendeu vários estilos, buscando a totalidade do objeto, com perspectivas diversas. Modigliani realizou na simplificação, no sintético, figuras com formas sincopadas, cabeças em elipse, braços e pernas geometrizados, detendo um padrão rítmico.

Em seu último autorretrato, os olhos estão negros, demonstrando o mistério da vida, a grande busca da sapiência do viver. Sua obra transmite-nos o todo de um ser, o desgaste pelo excesso e o viver pelo querer viver. A paleta demonstra que realmente foi um pintor, um pintor realizado. Sua postura corpórea indica a altivez da realização; seu semblante reflete um momento de fitar o outro para que possa se auto observar para poder existir em vida plena.

Esperamos ter demonstrado neste trabalho, com a análise da trajetória de vida e dos esboços com escritos de Modigliani e a interpretação de suas obras, especialmente seus retratos, que o artista incorporou em sua produção a tradição mística judaica, de maneira sutil e observável apenas para iniciados na Cabala, mas que fundamentou, sem

\footnotetext{
${ }^{146}$ Dante Alighieri (1265-1321) foi um escritor, poeta e político florentino, é considerado o primeiro e maior poeta da língua italiana, o poeta francês Victor Hugo (1802-1885) cita Dante como um dos gênios da humanidade.

${ }^{147}$ Isidore Lucien Ducasse (1846-1870) conhecido pelo pseudónimo literário de Conde de Lautréamont, poeta uruguaio que viveu na França. É o autor dos Cantos de Maldoror. Apreciada por André Breton (1896-1966) teórico do surrealismo, o considerava como um dos precursores do surrealismo; estudado por Gaston Bachelard (1884-1962) filósofo e poeta.
} 
dúvida, suas opções estéticas que resultaram num trabalho ímpar e admirado em todo o mundo acostumado a pensar em Modigliani como um gênio boêmio do modernismo.

Enfim, espera-se que com o presente estudo tenhamos lançado uma luz sobre a trajetória da vida e da obra de Modigliani como artista judeu que desenvolveu suas práticas fundamentadas nos princípios da tradição e da mística judaicas. Sua família, com profundas raízes no judaísmo, procurou ligar Modigliani a uma vida de conhecimentos e de tradição cabalista. As obras de Modigliani realmente transmitem introspecção mística, contida no pensamento de um judeu de tradição, mas, que pela sua originalidade e excepcional qualidade, trouxeram ao mundo um novo fazer, carregado de beleza e de emoção que, mesmo independente do embasamento na mística judaica, indicam uma excelência artística que fala por si só, sem necessidade de compreensão de seu universo pessoal, transcendendo qualquer rótulo que possa ser agregado ao seu mister de artista genial que atende à toda humanidade em sua busca pelo divino.

Esperamos, assim, que esta tese possa gerar questionamentos e que outros trabalhos venham a discutir e aprofundar as questões aqui suscitadas, promovendo um maior entendimento e reconhecimento sobre a vida e obra deste grande artista: Amedeo Clemente Modigliani! 
REFERÊNCIAS BIBLIOGRÁFICAS 


\section{REFERÊNCIAS BIBLIOGRÁFICAS}

ARGAN, Giulio Carlo. Arte Moderna. São Paulo: Companhia das Letras, 1992. História da Arte Italiana. São Paulo: Cosac\&Naify, 2003.

AJZENBERG, Elza. A poética de Amedeo Modigliani, O anjo de olhar grave. São Paulo: Poéticas Visuais II UNESP, 2011.

BAYET, Charles. Historia del Arte. Madrid: Fuente Cultural, 1980.

BELL, Julian. Uma nova História da Arte. São Paulo: Wmfmartinsfontes, 2008.

BENJAMIN, Walter. A modernidade e os modernos. Rio de Janeiro: Tempo Brasileiro, 2000.

BENSION, Ariel. O Zohar. São Paulo: Polar, 2006.

BIALE, David. Cabala e Contra-história: G. Scholem. São Paulo: Perspectiva, 2004.

BÍBLIA SAGRADA. São Paulo: Mirador, 1980.

BORDIEU, Pierre. O poder simbólico. Lisboa: Difel, 1989.

CAMPAGNANO, Ana Rosa; Judeus de Livorno. São Paulo: Humanitas, 2007.

CARNEIRO, Maria Lucia Tucci; LAFER, Celso. Judeus e Judaísmo, na obra de Lasar Segall. São Paulo: Ateliê Editorial, 2004.

CHATEAUBRIAND, Catálogo do Museu de Arte de São Paulo Assis. São Paulo: MASP, 2008.

CHATElET, Albert; GROSLEIR, Bernard Philippe. História da Arte. São Paulo: Larousse, 1991.

CHEVALIER, Jean; GHEERBRANT, Alain. Diccionario de los Símbolos. Barcelona: Herder, 1986.

DAMÁSIO, Antônio. O Mistério da Consciência. São Paulo: Cia das Letras, 2015.

DICIONÁRIO, Hebraico-Português. Rio de Janeiro: Vozes, 1988.

DORIN. Erwin. Dicionário de Psicologia. São Paulo: Melhoramento, 1978.

ELIADE, Mircea. O sagrado e o profano. São Paulo: Martins Fontes, 1992.

FRANCK, Dan. Paris Boêmia. Porto Alegre: L\&PM Editores, 2015.

FRAYZE-PEREIRA, João A. Arte, Dor. São Paulo: Ateliê Editorial, 2006. 
GALLAND, Maria Garcia Sol. Modigliani. Barcelona: Instituto Monsa, 2005.

GUEDES, Olívio; PARISOT, Christian; STRINATI, Cláudio. Modigliani imagens de uma vida. São Paulo: MCA, 2012.

GUINSBURG, Jacob. Coleção Judaica (13 Tomos). São Paulo: Perspectiva, 1967.

GOMBRICH, Ernest Hans A História da Arte. Rio de Janeiro: Zahar, 1978.

HAKANÁ, Nehuniah ben. Sefer ha-Bahir. Barcelona: Obelisco, 2013.

HAUSER, Arnold. História Social da Arte e da Literatura. São Paulo: M. Fontes. 1995.

HOUAISS, A. Dicionário Houaiss Eletrônico. Rio de Janeiro: Objetiva, 2009.

IDEL, Moshe. Cabala, Novas Perspectivas. São Paulo: Perspectiva, 2000.

JANSON, Horst Waldemar. História da Arte. São Paulo: Fundação Calousse, 1994.

KAPLAN. Aryeh. The Bahir. New York: Paperback, 1989. . Sêfer Ietsirá. São Paulo: Sefer, 2002.

KRYSTOF, Doris. Modigliani. Bonn: Taschen, 2009.

LACLOTTE, Michel. Petit Larousse de La Peinture (2 Tomos). Paris: Librairie Larousse, 1997.

LAFFONT, Robert. Encyclopédie des Mystiques. Paris: R. Laffont, 1972.

LEONE, Alexandre. Mística e Razão. São Paulo: Perspectiva, 2011.

LEITE, Edson. Antonietta, Guiomar e Magdalena: pianistas no Brasil. São Paulo: Acquerllo, 2011.

MAGALHÃES, Ana Gonçalves. Pintura italiana do entreguerras nas Coleções Matarazzo e as origens do acervo do antigo MAM. São Paulo: MAC USP, Tese de livre-docência, 2014.

MAE, Ana. Museu de Arte Contemporânea USP. São Paulo: Banco Safra, 1990.

MAILLARD, Robert. Dicionário da Pintura Moderna. São Paulo: Hemus, 1981.

MARÍN, José Luís. Diccionario de Iconología y Simbología. Madrid: Taurus, 1984.

MARTINS, Gilberto de Andrade. Manual para elaboração de monografia $e$ dissertações. São Paulo: Atlas, 1994.

MELLO, Dom Francisco Manuel. Tratado da Sciencia Cabala. Lisboa Occidental: Officina Bernardo da Costa de Carvalho, 1724. 
MERLEAU-PONTY, Maurice. Fenomenologia da percepção. São Paulo: Martins Fontes, 1999.

MICHALOWSKI, Kazimierz. Art of Ancient Egypt. New York: Abrams, 1986.

MODIGLIANI, Jeanne. Racconta Modigliani. Livorno: Graphis Arte, 1984.

NICOLA, Abbagnano. Dicionário de Filosofia. São Paulo: Mestre Jou, 1982.

NICOSIA, Fiorella. Modigliani. Paris: Gründ, 2011. Modigliani. São Paulo: Abril Coleções, 2011.

OLDENBOURG, Zoé. L'épopée des Cathédrales. Paris: Librairie Hachette, 1972.

PANOFSKY, Erwin. Significado nas artes visuais. São Paulo: Perspectiva, 1979.

PARISOT, Christian. Modigliani. La Vita le Opere. Roma: Carte Segrete, 2006. . Modigliani ritratti dell'anima. Roma: Modigliani Institut, 2010.

PARISOT, Christian; STRINATI, Cláudio; RIPOSATI, Massimo. Modigliani immagini di una vita. Roma: Carte Segrete, 2008.

PIJOAN, José. Historia del Arte (4 tomos). Barcelona: Salvat, 1969.

PIKE, Edgar Roysto. Diccionario de Religiones. México: F. C. Economica, 1986.

PIPER, David. Illustrated Dictionary of Art \& Artists. New York: Random House, 1984.

PATAI, Raphael. Os Alquimistas Judeus. São Paulo: Perspectiva, 2009.

RIPOSATI, Massimo. Modigliani, Simone Thiroux, un amore segreto/a secret love. Roma: Carte Segrete, 2009.

ROOB, Alexander. Alquimia \& Misticismo. Bonn: Taschen, 2001.

SAMPIERI, Roberto Hernandez; COLLADO, Carlos Fernández; LUCIO, María del Pilar Baptista. Metodologia da pesquisa. 3. ed. São Paulo: McGraw-Hill, 2006.

SCHOLEM, Gershon. Cabala. Rio de Janeiro: A. Koogan, 1989.

A correspondência de Walter Benjamin e Gershom Scholem, 1932-1940.

Cambridge: Harvard University Press, 1992.

STRINATI, Cláudio. Modigliani immagini di una vita. Roma: Carte Segrete, 2008.

SUH. Anna. Leonardo da Vinci cuadernos. Kerkdriel: Librero, 2014. 
TEIXEIRA, Luis Manuel. Dicionário Ilustrado de Belas-Artes. Lisboa: Presença, 1985.

TORÁ. Templo Israelita Ohel Iaacov. São Paulo: Sefer, 2001.

TSANEVA, Maria. Amedeo Modigliani, 122 Paintings and Drawings. New York: Lulu.com, 2014.

UNTERMAN, Alan. Dicionário Judaico. Rio de Janeiro: Zahar, 1992.

YEHUDA, Berg. Zohar. U.S.A.: Yehuda, 2013.

ZANIAH. Diccionario Esoterico. Buenos Aires: Kier, 1982. 
ANEXO 


\section{ANEXO Breve linha do tempo sobre a vida do artista Amedeo Modigliani}

1884 - Nasce em Livorno Amedeo Clemente Modigliani, em 12 de julho, às 09h00. Quarto filho de Flaminio Modigliani e de Eugénie Garsin, família sefardita.

1886 - Sua mãe inicia um diário e escreve: Será ele um artista?

1891 - Seu avô materno, Isacco Garsin, o inicia nos museus e na Cabala.

1894 - Morre seu avô Isacco.

1895 - Contrai pleurisia.

1897 - Bar mitzvá.

1898 - Sofre de febre tifoide com complicações pulmonares.

Lê poesias e ensaios.

Começa a estudar pintura com o Professor Guglielmo Micheli.

1902 - Recaída e ameaça de tuberculose.

Viaja por Florença, Roma, Nápoles e Capri.

Se inscreve na Escola Livre de Estudos de Nu, Florença.

1903 - Matricula-se na Escola de Belas-Artes de Veneza.

1905 - Pinta o estudo "Jovem Sentada".

1906 - Chegada a Paris.

1907 - Inscreve-se na Sociedade dos Artistas Independentes.

Conhece o Dr. Paul Alexandre, médico e comerciante de artes.

Expõe obras no Salão de Outono. 
1908 - Expõe a obra “A Judia” no Salão dos Independentes.

Desenha "Geometria e Cabala".

1909 - Pinta “A Amazona”.

No outono volta para Livorno.

Conhece o escultor Brancusi.

Trabalha em esculturas e, por isto, desenha muito.

Desenha "Estudo de Cabala Astrológica".

1910 - Expõe pela segunda vez no Salão dos Independentes.

Torna-se amigo de Max Jacob.

Conhece Anna Achmatova.

1911 - Expõe as "Pedras Arcaizantes”, estúdio de Amadeu S. Cardoso.

1912 - Conhece Jacques Lipchitz e Jacob Epstein.

Expõe oito esculturas no Salão de Outono.

1913 - Em Livorno joga cinco esculturas no rio (Assim reza a lenda).

Pinta "Busto rojo", uma das poucas nesta época.

1914 - Primeira Guerra Mundial.

Conhece Beatrice Hastings, escritora.

Conhece Paul Guillaume, galerista.

Expõe na Galeria Whitechaped, Londres.

Abandona a escultura, se dedica ao desenho e a pintura.

1915 - Pinta "Paul Guillaume".

Má saúde, produção mínima.

Fotografado em seu estúdio por Paul Guillaume.

Desenha "Símbolos judaicos".

Autorretrato como Pierrot. 
1916 - Torna-se amigo de Léopold Zborowski, marchand, seu protetor.

Pinta "Léopold Zborowski".

Séries de fotografias realizadas por Jean Cocteau.

Pinta "Max Jacaob".

Se relaciona com Simone Thiroux, tem um filho.

Pinta "Simone Thiroux".

Conhece Jeanne Hébuterne.

Desenha "Diego Rivera".

Pinta "Conrad Moricand”, astrólogo.

1917 - Expõe individualmente na galeria de Berthe Weil.

Pinta um série de nus, que serão famosos.

1918 - Ameaça de invasão alemã, viaja para a cidade de Nice.

Em novembro, nasce sua filha com Jeanne Hébuterne, Jeanne Modigliani, Nice.

Moricand faz "Mapa antológico de Jeanne Modigliani”.

Pinta uma série de três obras de "Jeanne Hébuterne".

Autorretrato como Rabino.

1919 - Reside na casa do pintor Andes Osterlin, pinta sua esposa Rachele.

Zborowski realiza várias exposições.

Modigliani volta para Paris.

Assina um documento se comprometendo a casar com Jeanne.

Pinta "Lunia Czechowska".

Autorretrato como Pintor. Última obra.

1920 - Em 24 de janeiro, morre no Hospital La Charité, às 20h45.

É enterrado no Cemitério Père-Lachaise.

Em 25 de janeiro, Jeanne Hébuterne, grávida, suicida-se.

1958 - Jeanne Modigliani escreve: « Modigliani senza leggenda ».

1984 - Jeanne Modigliani escreve: «Jeanne Modigliani Racconta Modigliani ». 